Florida International University

FIU Digital Commons

$10-27-2006$

\title{
Wading bird foraging ecology in a disturbed mangrove estuary in northwest Ecuador : commercial shrimp ponds vs. natural mangrove mudflats
}

Michael David Cheek

Florida International University

DOI: $10.25148 /$ etd.FI14060157

Follow this and additional works at: https://digitalcommons.fiu.edu/etd

Part of the Biology Commons

\section{Recommended Citation}

Cheek, Michael David, "Wading bird foraging ecology in a disturbed mangrove estuary in northwest Ecuador : commercial shrimp ponds vs. natural mangrove mudflats" (2006). FIU Electronic Theses and Dissertations. 2125.

https://digitalcommons.fiu.edu/etd/2125 
FLORIDA INTERNATIONAL UNIVERSITY

Miami, Florida

WADING BIRD FORAGING ECOLOGY IN A DISTURBED MANGROVE ESTUARY IN NORTHWEST ECUADOR: COMMERCIAL SHRIMP PONDS VS.

NATURAL MANGROVE MUDFLATS

A thesis submitted in partial fulfillment of the

requirements for the degree of

MASTER OF SCIENCE

in

BIOLOGY

by

Michael David Cheek

2006 
To: Interim Dean Mark Szuchman

College of Arts and Sciences

This thesis, written by Michael David Cheek, and entitled Wading Bird Foraging Ecology in a Disturbed Mangrove Estuary in Northwest Ecuador: Commercial Shrimp Ponds vs. Natural Mangrove Mudflats, having been approved in respect to style and intellectual content, is referred to you for judgment.

We have read this thesis and recommend that it be approved.

Peter Frederick

Joel Trexler

Jerome Lorenz

Thomas Philippi, Major Professor

Date of Defense: October 27, 2006

The thesis of Michael David Cheek is approved.

Interim Dean Mark Szuchman

College of Arts and Sciences

Dean George Walker University Graduate School

Florida International University, 2006 


\section{DEDICATION}

I dedicate this thesis to my wife Rosa, whose hard work in caring for our new son Jesse has allowed me time to complete this project. I would also like to dedicate this thesis to Rosa's father, Washington Segura Bayas, a generous and hard-working man who tragically lost his life during the course of this study. 


\section{ACKNOWLEDGMENTS}

I would like to thank the members of my committee for their technical support of this project. I thank Dr. Peter Frederick for his insightful advice regarding sampling design and field methods, wading bird foraging ecology, and several revisions of the thesis. I also thank Dr. Jerome Lorenz and Dr. Joel Trexler for their advice on sampling design and field methods. I thank Dr. Thomas Philippi for his financial assistance during pilot sampling in Ecuador and while working as a graduate assistant for several semesters as well as his assistance with sampling design and data analysis.

Field work in Ecuador would not have been possible without grants from the PADI Foundation and the Tinker Field Research program at Florida International University's (FIU) Latin American and Caribbean Center (LACC) and the Center for Transnational and Comparative Studies (TCS). I also could not have conducted hours of wading bird foraging observations and hundreds of throw-trap samples in the tropical heat without the assistance of my field technician "Platica" Quiñones and the small boat rented from Arturo Robles. I am grateful to all the shrimp farm managers and owners who granted me access to their property that is oftentimes heavily guarded against pirates. I sincerely thank former FIU graduate student Jorge Celi for providing Ecuador's Instituto Nacional de Meteorología e Hidrografía meteorological data from the study site, Dr. Thomas Chesnes for an early revision of the thesis, and Jason Blazer for assisting with data entry. Finally, I greatly appreciate the generosity and expertise of all the FIU graduate students who assisted me along the way. 


\author{
ABSTRACT OF THE THESIS \\ NATURAL MANGROVE MUDFLATS \\ by \\ Michael David Cheek \\ Florida International University, 2006 \\ Miami, Florida \\ Professor Thomas Philippi, Major Professor
}

WADING BIRD FORAGING ECOLOGY IN A DISTURBED MANGROVE

ESTUARY IN NORTHWEST ECUADOR: COMMERCIAL SHRIMP PONDS VS.

I compared wading bird foraging ecology in commercial shrimp ponds and natural mangrove mudflats in the Muisne River Estuary in northwest Ecuador. I estimated foraging habitat suitability by observing the foraging efficiency, diet, and behavior of great (Ardea alba) and snowy (Egretta thula) egrets, censusing birds, and measuring prey availability (i.e. prey density, standing crop, water depth, and diversity). Great egrets had greater foraging efficiency in shrimp ponds, while snowy egret foraging efficiency was greater on mudflats. Over $85 \%$ of prey items in snowy egret boluses were from shrimp ponds. Mean density, standing crop, length, and mass of prey items was significantly greater in shrimp ponds, but availability was limited by water depth and diversity. Great and snowy egrets utilized shrimp ponds as their primary foraging grounds, while all other diumal wading bird species foraged primarily on mudflats, where the diversity of wading birds and their prey was greatest. 


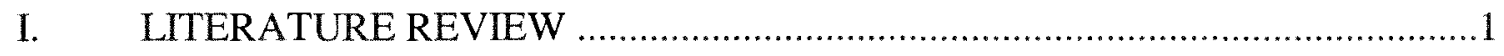

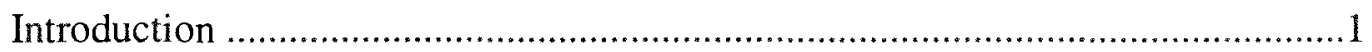

Wading Birds in Human-modified Habitats .....................................................

Wading Birds in Mangrove Habitat ................................................................11

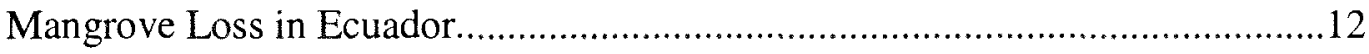

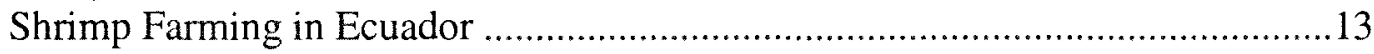

Shrimp Culture Species and Production ..........................................................14

Pond Culture Types in Ecuador .................................................................16

Coastal Ecuador, 'Biodiversity Hotspot' ...........................................................19

II. PROJECT SIGNIFICANCE, GOALS AND OBJECTIVES .....................21

Research Needs and Project Significance ............................................................21

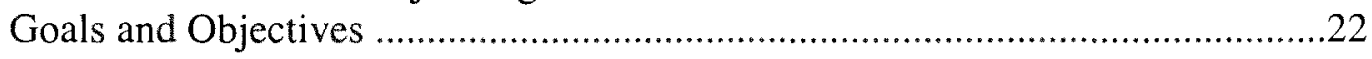

Research Questions and Hypotheses ..............................................................23

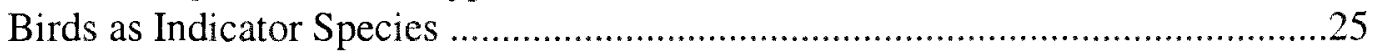

Wading Birds as Indicators of Habitat Quality ...............................................26

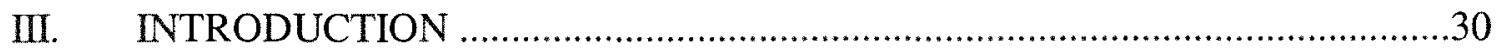

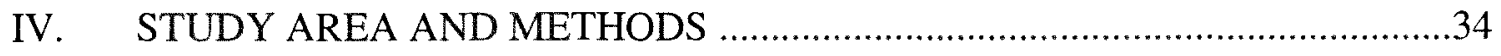

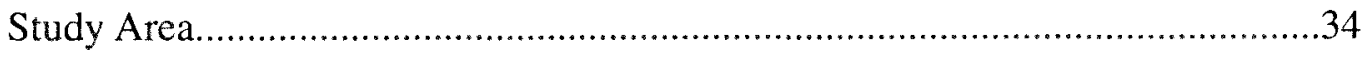

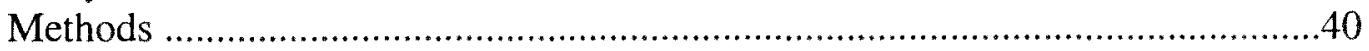

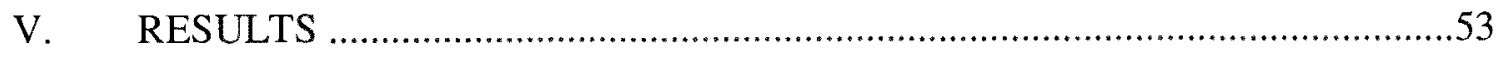

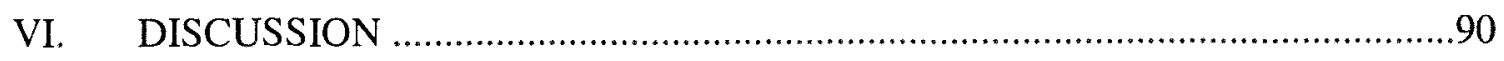

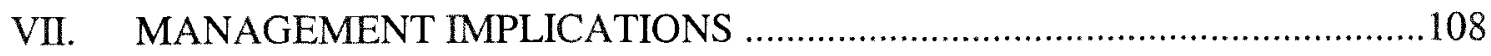

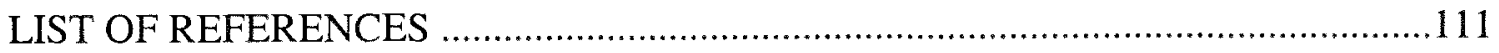

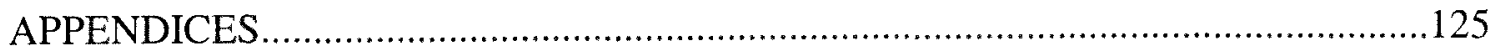




\section{LIST OF TABLES}

TABLE

PAGE

1. Area (has) of Natural Mudflats and Shrimp Ponds .................................................42

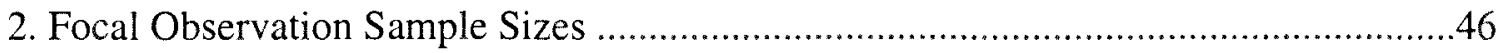

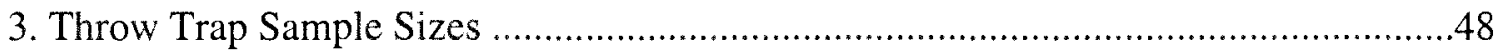

4. Population Size of Las Manchas Wading Bird Colony ..............................................54

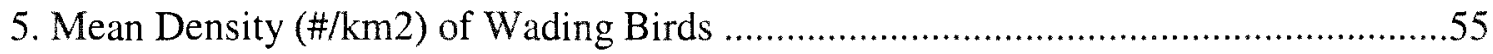

6. Comparison of Peak Wading Bird Density With Other Study Sites ............................56

7. Percentages of Wading Birds in Natural Mudflats and Shrimp Ponds ........................57

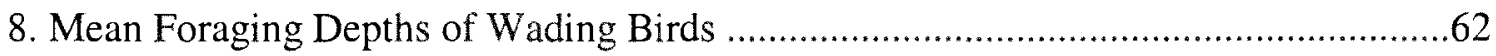

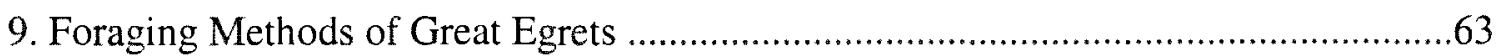

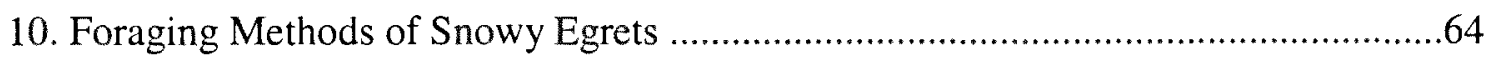

11. Strike, Capture, and Foraging Efficiency of Great and Snowy Egrets ......................66

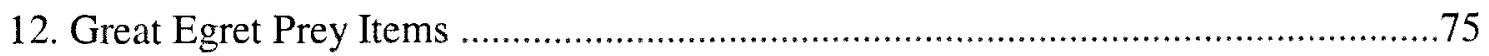

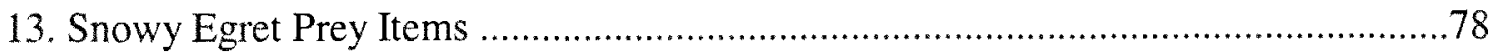

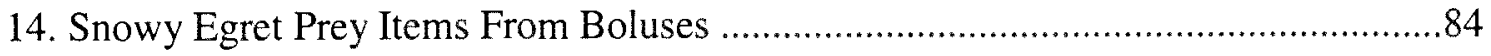

15. Summary of Prey Items Captured During Throw Trap Sampling ............................8 
FIGURE

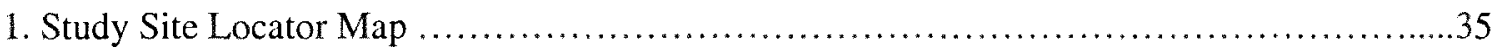

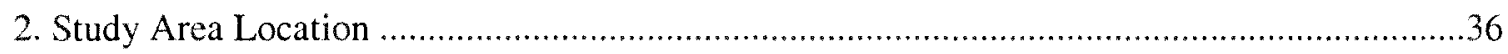

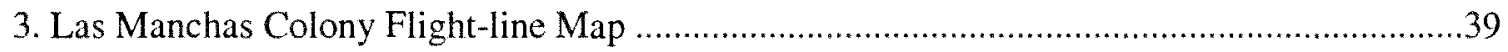

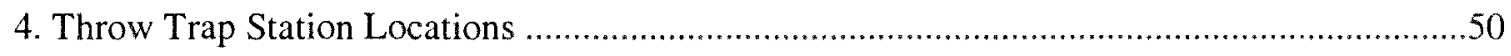

5. Microhabitats Utilized by Great and Snowy Egrets .............................................. 59

6. Microhabitats Utilized by All Wading Bird Species ..................................................60

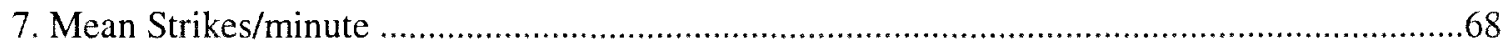

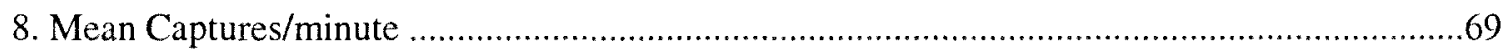

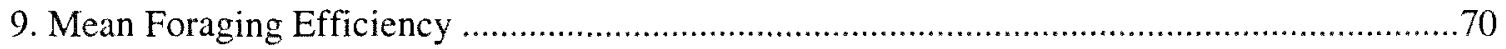

10. Mean Length of Great and Snowy Egret Prey Items ............................................ 71

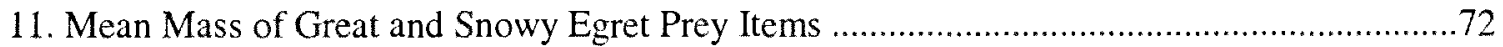

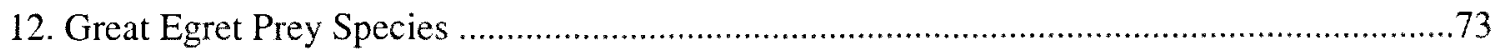

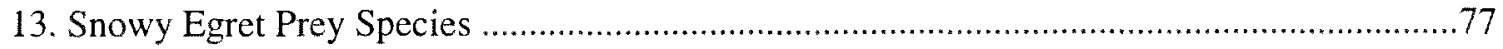

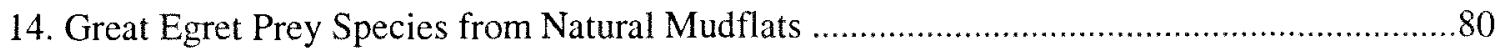

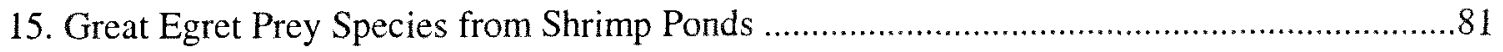

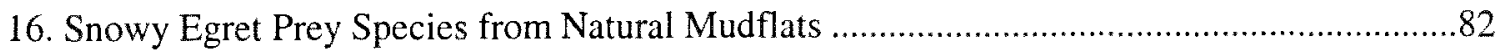

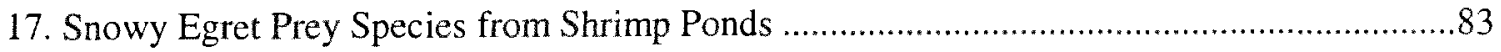

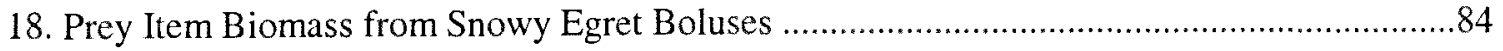

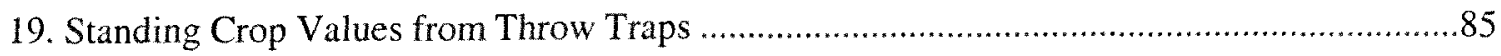

20. Mean Mass of Prey Items from Throw Traps …...................................................... 86

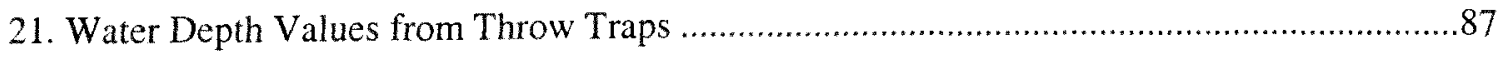

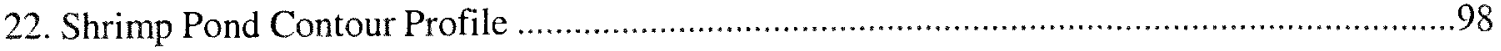




\section{LITERATURE REVIEW}

Introduction

As ecosystems throughout the world become increasingly impacted by anthropogenic change, the need to assess the significance of this influence on biodiversity and ecological functions is increasing (Kushlan 1993). Evaluating the ability of humanmodified landscapes to serve as surrogates for natural habitats for vertebrate animal populations is a current goal in conservation biology (Elphick 2000). Colonial wading birds (Ciconiiformes) have been utilized as indicators of ecosystem level human impacts in the Florida everglades due to aspects of their basic biology, regional understanding of their ecology, and their visibility and interest to the public (Frederick and Spalding 1994;

Davis 2001). The ecology of wading birds in both natural and human-modified habitats in various temperate zone regions has been well documented (Kushlan 1978; Spanier 1980; Brush et al. 1986; Erwin et al. 1986; Hafner et al. 1986; Hafner 1997; Bildstein et al. 1994; Cezilly 1992; Frederick and McGehee 1994; Fasola and Ruiz 1996; Richardson et al. 2001, 2003). However, there is a relative paucity of parallel information from the neotropics, where global biodiversity of waterbirds is greatest and habitat destruction is often ineffectively regulated (Meyers et al. 2000). This fact is particularly salient in the mangrove ecosystems of Central and South America, where large-scale mangrove conversion has expanded at unprecedented rates over the past 20-30 years as a result of human population pressures and commercial aquaculture (Ewel et al. 1998). Baseline information on wading bird ecology in the mangrove ecosystems of this region is of particular importance for several reasons. First, large populations of wading birds in the 
tropics may depend exclusively on coastal mangroves for nesting and numerous migratory species utilize mangrove habitat during different seasons (Bildstein et al. 2002: Lefebvre and Poulin 1997). Second, the high rate of habitat loss increases the need to understand the ecological impacts that habitat disturbance is having on wading birds and their prey base (Valiela et al. 2001). Finally, many impoverished local human populations in the region depend on the goods and services provided by mangroves, further affirming the necessity of habitat conservation plans based on site-specific data (Ewel et al. 1998; Kushlan 1997).

Wading birds regularly use anthropogenically disturbed habitats such as rice fields, aquaculture ponds, stormwater retention ponds, salt pans, refuse dumps, and nuclear reactor cooling reservoirs (Velasquez 1992; Bildstein et al. 1994, Richardson et al. 2001, Gawlik 2002). However, the relative suitability of these areas as surrogates for natural foraging grounds is often unknown, especially within the borders of developing nations. The intensity and spatial extent of the habitat alteration, the presence of suitable adjacent habitat, and the species life history characteristics (e.g. morphology, physiology, behavior) all contribute to the net ecological impact of habitat degradation on wading bird populations.

Global concern has been raised about the negative environmental impacts and long-term sustainability of shrimp aquaculture in coastal Ecuador, although few scientific studies have examined the issue. The conversion of natural mangrove areas to shrimp farms may be detrimental to a wide variety of wildlife species that breed and forage in mangrove estuaries along the coast. Due to water depth in many semi-intensive and intensive ponds $(\geq 1 \mathrm{~m})$, prey availability to foraging wading birds is probably reduced 
since local species generally forage in water less than $30 \mathrm{~cm}$ deep. Conversely, shrimp ponds often contain unnaturally high densities of suitable prey items available to wading birds along the pond shorelines and during harvest events that may mitigate the effects of any loss of natural foraging grounds. Some shrimp farmers contend that wading birds are nuisance predators of their crops and implement management efforts to defend against predation and economic loss. Here I compare the seasonal use of commercial shrimp ponds and adjacent natural mangrove mudflats to estimate the relative suitability and importance of shrimp farms as foraging habitat for wading birds in the Muisne River estuary in northwest Ecuador, an area highly impacted by shrimp farming over the last 10 years.

The feeding ecology of wading birds in shrimp aquaculture ponds has remained undescribed. The Pacific coast of Ecuador offers a unique opportunity in which to examine the potential effects of shrimp farm construction in mangrove estuaries on wading birds and their prey. Comparisons are made with previous work conducted in both temperate and tropical latitudes and offer new insight into wading bird prey bases, adaptability to disturbance, and plasticity in foraging behavior. Data collected in this region will also assist local, regional (e.g. Partners in Flight and Waterbird Conservation of the Americas), and global (e.g. Ramsar Convention on Wetlands, Wetlands International, and the World Conservation Union-IUCN) biodiversity conservation efforts focused on protecting critical wildlife habitats of international importance and promoting the wise use of natural resources. 
Wading Birds in Human-modified Habitats

Wading birds are known to forage in human-modified wetlands and estuaries throughout the world. Habitat types used include agricultural lands, aquaculture ponds, wastewater treatment wetlands, power plant cooling ponds, mosquito impoundments, mitigation/restored wetlands, mining sediment ponds, eutrophic lakes, reservoirs, stormwater retention ponds, roadside culverts and drainage ditches, golf courses, and residential neighborhoods. A study of rice fields in Japan suggests that rice fields are not the preferred habitat of great egrets (Ardea alba) or grey herons (Ardea cinerea) due to low abundance of large fish $(>10 \mathrm{~cm})$, a preferred prey type of both species (Lane and Fujioka 1998). In contrast, the predominantly terrestrial cattle egret (Bubulcus ibis) was commonly observed feeding on orthopterans along rice paddy berms (Lane and Fujioka 1998). While invertebrate prey densities in California rice fields did not differ from seminatural freshwater wetlands, great egret foraging efficiency was greater in the seminatural wetlands than in either flooded or unflooded rice fields (Elphick 2000). In northern Italy, the number of foraging herons, prey intake rates, and prey abundance were higher in rice fields than in natural habitats (Fasola et al. 1996). Fasola (1986) estimated that rice fields in Italy provide food for $46 \%$ of the black-crowned night herons (Nycticorax nyticorax) and 39\% of the little egrets (Egretta garzetta) breeding in the country. Greater percentages (69\% and $96 \%$ respectively) of the populations are supported by them in northern Italy, where rice fields cover approximately $30 \%$ of the landscape, (Fasola 1986). However, the same species of herons in the Camargue area of France have lower prey intake rates in rice fields than they do in Italy, indicating variability in prey availability in the same habitat type (Fasola 1986). Some of this 
variability may be due to the use of pesticides to control the phyllopod Triops cancriformes and chironomid larvae (both Ardeid prey items) in the Camargue and that have been linked to declines in the use of rice fields by little egrets (Hafner et al. 1986). Overall, rice fields in 4 of the 5 rice cultivation regions of Mediterranean Europe provide most of the food acquired by 6 species of breeding heron in the region (Fasola and Ruiz 1996; Fasola et al. 1996). It should be noted however, that the natural wetlands in these areas: northwest Italy, the Po Delta in northeast Italy, the Rhone Delta in France, the Axios Delta in Greece, and the Ebro Delta in Spain, have been reduced to only $10-20 \%$ of their original area, suggesting that the birds may have adapted to new foraging conditions and are not preferentially selecting rice fields (Fasola and Ruiz 1996; Fasola et al. 1996). In southern New South Wales, Australia, Richardson et al. (2001) suggested that rice fields may be inferior to natural wetlands as foraging areas for great and intermediate egrets (Ardea intermedia) due to lack of large fish, a more limited range of prey types, and a decline in prey capture rates when breeding birds are feeding young and energy requirements are presumably at their highest. The cattle egret did not experience the same decline in capture rates as the breeding season progressed due to a less variable terrestrial diet of insects (Richardson et al. 2001). Only 5-13\% of the great and intermediate egrets available to feed within the study area foraged in rice fields, while up to $60 \%$ of available cattle egrets did so, suggesting that rice fields may facilitate the spread of this invasive species (Richardson and Taylor 2003). Flooded fallow sugar cane (Saccharum officinarum) fields in south Florida were utilized as foraging habitat by at least 11 ardeid species during late summer and early fall, although no simultaneous comparisons with natural habitats were made (Sykes and Hunter 1978). 
Numerous studies at aquaculture facilities in the southeastern United States have shown that at least 12 species of wading birds feed on a variety of cultured species such as bait fish (family Cyprinidae), channel catfish (Ictalurus punctatus), crayfish (Procambarus spp.), tropical ornamentals, salmon and trout (family Salmonidae), and tilapia (Oreochromis spp.)(Werner et al. 2000). Great egrets and great blue herons (Ardea herodias) are the most common Ardeid predators at catfish farms where great egrets preferred small fingerlings $(7.5-10 \mathrm{~cm})$, comprising $\approx 8 \%$ of the biomass of all food items taken, while great blue herons consumed fish averaging $15 \mathrm{~cm}$ which made up over $44 \%$ of the diet (Glahn et al. 1999; Werner et al. 2001). Draulans (1988) argued that grey herons could consume a maximum of $8 \%$ of the total fish yield in cyprinid ponds in Belgium and the Netherlands, depending on prey availability (a function of stocking density, water depth, and turbidity). This level of predation was deemed insignificant relative to natural mortality rates. He also indicated that predation could be much higher during times of increased prey availability such as when ponds are being drained for harvest. Eleven wading bird species use aquaculture ponds to varying degrees throughout the year in Deep Fish Bay, Hong Kong, although overall bird species richness was lower than in natural adjacent wetlands (Chu 1995). Maximums of $100 \%, 72 \%$, and $49 \%$ of available cattle egrets, Chinese pond herons (Ardeola bachus), and little egrets, respectively, fed in fish ponds during the study (Young 1998). Juvenile Chinese pond herons fed significantly more often in the fish ponds than adults, and $79.9 \%$ of great egrets fed on mudflats and only used ponds in proportion to their availability (Young 1998). Additionally, $9.6 \%$ of Chinese pond herons fed in traditional intertidal shrimp ponds (gei wai), while $37.4 \%$ fed in fish ponds (Young 1998). Among Chinese pond 
herons, cattle egrets, little egrets, and great egrets, only the little egret utilized gei wai ( $2 \mathrm{~m}$ deep) in proportions greater than local availability during the winter (Young 1998).

Exponential population growth of some colonial wading birds (order

Ciconiiformes) over the past 40 years in Louisiana have been attributed to the increased acreage of crayfish aquaculture in the region (Fleury and Sherry 1995). Waders such as snowy egrets (Egretta thula) and yellow-crowned night herons (Nyctanassa violacea), that specialize on crustaceans, have seen their numbers increase simultaneously with wild crayfish harvests and commercial crayfish acreage in Louisiana. Pond drawdowns, which typically coincide with the wading bird breeding season, concentrate prey and may contribute to increased local recruitment. However, several other non-exclusive factors could potentially explain the trend such as climate change, long-term recovery of harvested species, decreased use of pesticides, and habitat loss elsewhere (Fleury and Sherry 1995).

Snowy egrets, green herons (Butorides virescens), tricolored herons (Egretta tricolor), and little blue herons (Egretta caerulea) were the principal predators at 7 tropical aquaculture facilities in central Florida where they removed an estimated $37.6 \%$ of the stocked fish in unnetted ponds and caused an estimated monetary loss of approximately US $\$ 1,360$ /pond (Avery et al. 1999). Non-lethal efforts to control such losses have been implemented with varying degrees of success at numerous locales and can include wires, monofilament, netting, pyrotechnics, flashing electric lights, scarecrows (Andelt et al. 1997), distress calls of conspecifics (Spanier 1980), turbidity (Cezilly 1992), electric fences (Mott and Flynt 1995), and habitat modifications. Several authors suggest that effective anti-predation control efforts be directed toward particular 
known problematic species at appropriate times during the growth cycle of the cultured animals within individual ponds (e.g. disperse great egrets only from ponds containing catfish $<10 \mathrm{~cm}$ in length, not dispersing all birds from all ponds on a farm).

Densities of ardeids in central Florida wastewater treatment wetlands were similar to those in natural freshwater marshes (Frederick and McGehee 1994). However, the artificial sites served as important breeding colony locations for wood storks (Mycteria Americana), cattle egrets, and great egrets and feeding habitat for great egrets and snowy egrets, while wood storks and white and glossy ibises (Eudocimus albus and Plegadis falcinellus) foraged predominantly in natural wetlands with shallower water more suitable for tactile foragers (Frederick and McGehee 1994). At a power plant cooling reservoir in Texas, the great blue heron (Ardea herodias), great egret, green heron, and snowy egret utilized the 'heated' portion of the lake in greater proportion than the 'main' part of the lake, a portion which was relatively less disturbed (Esler 1992).

At least 7 species of ciconiiforms used three power plant cooling ponds in south Carolina (Bildstein et al. 1994). Nesting success of wood storks in coastal man-made impoundments was reported equal to that of interior, natural sites during the same years in Florida by Ogden (1985). Non-tidal impoundments in the upper Delaware Bay in Delaware and New Jersey had a greater abundance (individuals $/ \mathrm{km}$ ) of 10 species of wading birds than adjacent natural tidal marshes during a 5-year study (Parson 2002). Impoundments in coastal New Jersey had greater avian species diversity than natural marshes or ditched marshes, including numbers of individuals and biomass of wading birds (Burger et al. 1982). Over $91 \%$ of wading birds observed during aerial surveys (1993-1994) in the Indian River Lagoon, on the Atlantic coast of Florida, were in 
managed impoundments, while only $8.5 \%$ were observed in open waters of the natural lagoon (Schikorr and Swain 1995). However, estimates of habitat availability were not given, but it was estimated that over $90 \%$ of the natural habitat within the lagoon has been affected by mosquito impoundments. Eight species of wading birds were present in coastal mosquito impoundments at the Kennedy Space Center in east-central Florida $77 \%$ of the time during monthly surveys conducted in 1984-1985 (Breininger and Smith 1990). Wading bird use of these impoundments corresponded with lowering water levels, increased prey abundance, and increased nesting activity of adjacent breeding colonies from February through April. In South Carolina, species richness of wading birds was greater in managed than unmanaged coastal impoundments, and of 77 wetland bird species, $76(99 \%)$ were recorded using managed sites while $56(72 \%)$ were recorded using unmanaged sites, 15 of these species were Ciconiiformes (Epstein and Joyner 1986). Fish-eating birds (including 22 Ciconiiformes) in savannas of the Venezuelan llanos were more abundant in impounded areas than in natural adjacent habitat types due to greater prey densities; species diversity however, was greater in non-impounded areas (Morales and Pacheco 1986). Use of these impoundments, as in most artificial and natural systems, was affected by time of year, management, surface area, and availability of prey. Mitigation/restored wetlands created for use by the endangered wood stork have successfully attracted foraging wading birds in various locations in South Carolina (Coulter 1990) and south Florida (Murdock 1987). Mining sediment ponds in east Texas were regularly used by 7 species of wading birds during the breeding and post-breeding seasons and phosphate mines in north-central Florida were heavily used by 6 ciconiiform species for feeding and nesting (Renfrow M.S. thesis; Maehr 1981). During a study of 
foraging ecology in central Florida, Edelson (M.S. thesis) found that 12 species of wading birds utilized a hyper-eutrophic lake (Lake Hancock) and that tagged snow egrets "foraged more often, in larger groups, and flew farther to feed in artificial habitats associated with phosphate mining than they did in natural habitats". The apparent preference for disturbed habitats in this case was attributed to the high biological productivity in the human-modified wetlands and concomitant increase in prey densities. High densities of a preferred prey item (coprophilic beetles) found in guano piles at a poultry farm in La Paz, Baja California Sur, Mexico, provided superior foraging habitat for 50 to 500 migratory white-faced ibises (Plegadis chihi) relative to adjacent natural habitat (Blanco and Rodriguez-Estrella 1998). However, there are potential detrimental effects to wading birds foraging in artificial habitats. Negative impacts on wading birds foraging in human-modified environments may include greater exposure to toxic compounds used in agriculture and industry (Custer 2000; Hafner and Dugan 1986), increased parasite loads (Frederick and McGehee 1994), reduced prey availability due to turbidity (Cezilly 1992) and use of pesticides (Fasola and Ruiz 1996; Hafner and Dugan 1986), and persecution because of perceived predation losses (Marion 2000).

Environmental contaminants known to affect wading bird reproduction in agricultural areas include organochlorine insecticides, polychlorinated biphenyls, dioxins (and related compounds), organophosphorous and carbamate insecticides, petroleum, and trace elements (e.g. mercury, lead, cadmium, and selenium)(Custer 2000). Species known to be affected by these contaminants include grey herons (Ardea cinerea), black-crowned night herons, great blue herons, great egrets, green herons, snowy egrets, cattle egrets, purple 
herons (Ardea purpurea), little egrets, and squacco herons (Ardeola ralloides)(Custer 2000).

Wading Birds in Mangrove Habitat

The value of mangrove ecosystems to humans and wildlife has been well documented in various locations throughout the world (Odum and McIvor 1985, 1998; Blanchard and Prado 1995; Ellison and Farnsworth 1996; Bancroft et al. 1997; Ewel et al. 1998). Direct benefits provided by mangroves include soil stabilization, sediment trapping, nutrient processing, water quality improvement, providing habitat and food for a wide variety of animals, and supplying plant products for anthropogenic uses. Additionally, mangrove ecosystems are considered attractive to tourists as an aesthetically pleasing environment where coastal forest meets sea (Hamilton and Snedaker 1984).

The importance of mangroves to wading birds in the Americas has been well documented (Haverschmidt 1965; Frederick and Spalding 1997; Miranda and Collazo 1997; Ewel et al. 1998; Lorenz et al. 2002). Mangroves serve as nighttime and high tide roosts, feeding and nesting habitat, and evergreen feeding habitat in highly seasonal tropical forests for boreal, austral, and intra-neotropical migrants. Mangrove forests throughout the neotropics commonly support the most stable, and often times largest, regional colonies of breeding wading birds. Over $90 \%$ of the documented "supra-normal" wading bird nesting events observed in Florida during the 1930's and 1940's occurred in the freshwater marsh-mangrove ecotone region of the southern everglades (Crozier and Gawlik 2003). Trinidad's Caroni Swamp, a 5611 ha mangrove-dominated estuary, is 
home to $39 \%$ of the island nations' avifauna including 18 species of wading bird, 14 of which reach population maximums within the swamps' mangrove forests (Bildstein et al. 1991). The Usumacincta-Grijalva delta along the gulf coast of Mexico is the countrys' largest mangrove estuary and often supports the largest colonial waterbird breeding colonies in the country (Bildstein et al. 2002). Haverschmidt (1965) observed 7 Ciconiiform species nesting (excluding 3 species unconfirmed as breeders) in mangroves in coastal Surinam. These coastal wetlands offer ready access to both nesting substrate and diverse foraging habitat in freshwater marshes, brackish estuaries, and saltwater mudflats and mangrove keys harboring a varied prey base of euryhaline species originating in both salt and freshwater environments. However, in a review of 31 studies examining the density of fish or decapods in mangrove, seagrass, coral reef, saltmarsh, and non-vegetated habitats, results indicate that mangrove estuaries do not consistently harbor the greatest prey densities relative to surrounding coastal habitats (Sheridan and Hays 2003; Lorenz 1999).

Mangrove Loss in Ecuador

Despite the wealth of literature demonstrating the socio-economic and ecological goods and services that mangrove ecosystems offer, mangrove habitat throughout the world continues to be destroyed at an alarming rate. Recent global estimates indicate that approximately $2,834 \mathrm{~km}^{2}(2.1 \%)$ of mangroves have been lost annually for the past two decades (Valiela et al. 2001). This represents an overall global loss of approximately $35 \%$ of the original mangrove area, the largest percentage having occurred in the Americas (38\%)(Valiela et al. 2001). Most large-scale cutting and subsequent filling of mangrove 
areas has been for direct resource extraction, land reclamation for agricultural, industrial, and urban development, and conversion to shallow diked ponds dedicated to salt production or mariculture (Valiela et al. 2001). Worldwide, mariculture practices are responsible for the largest proportion of total mangrove loss (38\%)(Valiela et al. 2001). The species most often cultivated in mariculture ponds in the Americas is the commercially important white shrimp (Penaeus vannamei). The largest conversion of mangroves to shrimp ponds in the Americas has occurred in Ecuador, where over $21 \%$ (35,219ha) of former mangrove habitat has been destroyed since 1984 (CLIRSEN 1999). Approximately $40 \%$ of this loss is attributed directly to the construction of shrimp aquaculture ponds.

Shrimp Farming in Ecuador

The conversion of mangrove estuaries to shrimp farms began approximately 30 years ago, when the centuries-old tradition of mariculture was introduced from Asia (Ewel et al. 1998). Western Hemisphere countries produced an estimated 28 percent of the world's farmed shrimp in 1998 , or 207,000 metric tons, 63 percent $(130,000$ metric tons) of which was exported by Ecuador alone (USDA 1999). Nearly 65 percent is marketed in the United States ( $\$ 1.3$ billion worth of frozen shrimp) and 30 percent in Europe, primarily to France, Italy, and Spain (USDA 1999). The United States receives most of its' middle-sized shrimp from Ecuador and Thailand. Global production in 2000 was 1.1 million metric tons with an estimated wholesale value of US\$ 6.9 billion (USDA 1999). 
Shrimp Culture Species and Production

In the Eastern Hemisphere, tiger shrimp (Penaeus monodon) is the most popular species in pond culture. The western white shrimp (Penaeus vannamei) is the predominant species farmed in Ecuador and most other Latin American countries (USDA 1999). Most cultivated species are associated to varying degrees with mangrove estuaries during some portion of their life cycle. The natural life cycle of white shrimp in Ecuador begins with the release of larvae from gravid females into the nearshore ocean waters where they drift with currents, tides, and wave action. After drifting as plankton for a short period, the shrimp quickly grow larger (post-larvae, $1-15 \mathrm{~mm}$ ) and survivors begin to make their way into coastal estuaries where they seek the protection of shallow water, mangrove prop roots, and the nourishment of abundant primary productivity. Much of the planktonic food (detritus, phytoplankton, and zooplankton) of the shrimp is directly dependent upon the organic matter and nutrients exported by the riverine mangrove systems where a significant proportion of the biomass may consist of mangrove litterfall (Dittel et al. 1997). The post-larvae develop in the estuary to approximately half their adult size $(45 \mathrm{~g})$ in several months and begin to migrate towards the ocean where they reach maturity, reproduce, and release larvae, starting the cycle again (Odum and Arding 1991).

Shrimp farming in Ecuador requires stocking the ponds with larvae or small postlarvae (1-7mm) and monitoring ponds during a 3-4 month growth cycle, at which time the shrimp are harvested at slightly less than half their potential size (12-17g)(Pacheco 2004). Larvae for stocking ponds are either wild-caught from beaches, rivermouths, and estuaries, or raised in a laboratory from gravid females of superior fitness (see Pond 
Culture Types below). Inputs into semi-intensive and intensive ponds during the growth cycle may include fishmeal feed, nitrogen and phosphorous to stimulate phytoplankton growth, antibiotics (see below), and agricultural limestone $\left(\mathrm{CaCO}_{3}\right)$ to balance the $\mathrm{pH}$ of often acidic mangrove soils (Yoder, per. com.; Sonnenholzner and Boyd 2000). Perimeter berms are constructed approximately 1-2 meters above the smoothed pond bottom and the pond is filled with local estuarine water to a depth of approximately $0.5-2$ meters. The pond bottom is often gently sloped towards one end so the entire pond can be drained for harvesting and for maintenance activities. Ponds are typically located above mean high tide so that they are not breached by extreme tidal or flooding events such as El Nino years when elevated sea levels combine with heavy rains. Low input extensive ponds (see below) may be constructed closer to the mean high water level so that they may fill naturally during the monthly spring tides without utilizing costly gasoline pumps.

Ponds are harvested by slowly draining the pond over a period of 1-2 days and either netting shrimp within the pond once water levels are approximately $20-30 \mathrm{~cm}$ deep, or collecting shrimp in a large net that is placed on the downstream side of an open water control structure while the pond drains completely. Harvested shrimp are then placed on ice (usually in small boats) and transported by water to the nearest packing plant. Due to Ecuadors' warm climate and highly productive estuarine waters, shrimp culture may continue year-round, producing a maximum of 3 harvest events annually in some parts of the country. 
Pond Culture Types in Ecuador

Intertidal mangrove forests, mudflats, and salt pans have been favored locations for the construction of shrimp ponds in the past for several reasons. These areas have historically been unoccupied, state owned lands lacking significant legislative protection. They require low investment cost and technical expertise to prepare for pond construction, allow for tidal exchange (no costly pumps), contain a natural supply of shrimp larvae, and often possess infrastructure previously established for the capture and distribution of wild-caught shrimp within estuary channels. Impoverished human populations, often comprised of fisherman, are also locally available for employment and perceive the endeavor as a highly profitable short-term investment (Lewis et al. 2002) Extensive farms

In some traditional systems, termed "trapping and holding" operations, wild shrimp and other aquatic species are carried into the pond by tidal flow, isolated from the adjacent estuary, and harvested after a suitable residence time within the ponds (Lewis et al. 2003). These 'traditional' systems are typically large, shallow ponds constructed in the intertidal zone. Shrimp larvae stocking densities are low, water exchange is by tidal movement, and shrimp yields are typically less than $500 \mathrm{~kg} / \mathrm{ha} / \mathrm{yr}$, and sometimes as low as $50 \mathrm{~kg} / \mathrm{ha} /$ year today (Lewis et al. 2003). Extensive ponds range in size from 10-100ha with most ponds averaging 10-30ha (Lewis et al. 2002).

Semi-intensive farms

Semi-intensive farms typically involve stocking the ponds with hatcheryproduced post-larvae in addition to wild-caught larvae at densities of 25,000-100,000 post-larvae/ha and input of feeds and fertilizers increases shrimp yields to approximately 
$1000-3000 \mathrm{~kg} / \mathrm{ha} / \mathrm{yr}$ (Lewis 2002). Ponds are typically smaller (2-30ha) and can be located on intertidal land as well as supra-tidal uplands well above mean high tide. These areas facilitate the draining of ponds during harvest events and allow for complete drying between crops. Natural tidal water exchange is replaced by mechanical pumps which attempt to replace $5-10 \%$ of pond volume per day, although some farms have reduced water exchange through ponds in recent years due to the increased presence of introduced and native pathogens present in estuary waters receiving outflow from infected neighboring ponds (see Intensive Farms and Pathogens below)(Lewis 2002). Intensive farms

Intensive farms have smaller ponds $(<1 \mathrm{ha})$ with higher stocking densities (200,000 post-larvae/ha and above), heavier feeding rates, and yields of 5,000 to 10,000 $\mathrm{kg} / \mathrm{ha} / \mathrm{yr}$ are common (Lewis 2002). Intensive farms located in estuarine environments are prone to pathogen outbreaks due to pond overpopulation. Consequences of overstocking include increased stress, poor nutrition, increased rate of spread of disease through greater contact with conspecifics, and introduction of infected water. Attempts aimed at curbing disease include a recent trend toward the use of intensive "greenhouse" farms. At significant expense, ponds are covered completely in plastic nursery-grade tarps to increase air temperatures to $>38^{\circ} \mathrm{C}$ and water temperatures to $30-33^{\circ} \mathrm{C}$, thereby creating a hostile environment for many pathogens. Stocking of intensive ponds is with laboratory larvae only and can be as high as $1,000,000$ post-larvae/ha, resulting in 9,000$13,600 \mathrm{~kg} / \mathrm{ha} / \mathrm{yr}$ (Yoder 2003 pers. comm.) This method is practiced increasingly in upland areas of coastal Ecuador using freshwater wells and avoiding contaminated 
estuary water altogether. However, maintaining appropriate water quality parameters such as salinity may become problematic in these regions.

Polyculture

This involves the simultaneous stocking of two or more aquatic species in the same pond. Currently in Ecuador polyculture can be considered intensive or semiintensive and involves growing shrimp and euryhaline fish such as tilapia (Oreochromis spp.) and the Pacific fat sleeper (Dormitator latifrons).

Pathogens

The two most common in Ecuador are white spot disease (WSD) introduced from Asia and Taura syndrome (TS) from Central America. Both can infect cultured $P$. vannamei and have been observed in some wild-caught specimens. Transmission vectors include contaminated water, decomposing fecal matter or animal tissue, cannibalism of infected shrimp, and body fluid of infected females (Pacheco 2004). WSD is named for the characteristic white spots that begin to form on the animals' carapace. Infected animals stop feeding, swim irregularly near the pond surface, exhibit lethargy, and may die within 7 days of initial exposure (Yoder 2003 pers. comm.). Symptoms of Taura syndrome are similar to WSD, differing slightly in that animals may turn reddish in color and the carapace softens. Proactive measures are the only defense against both viruses as there is no known treatment and the virus may cause $100 \%$ mortality within a pond. Interestingly, shrimp farmers recognize increased wading bird use of ponds as a signal of epizootic outbreaks due to the increased susceptibility of infected shrimp to predation. In some instances when shrimp are near harvestable size and the pond becomes 
contaminated, they can be harvested early to avoid further spread of the outbreak and minimize economic loss.

\section{Coastal Ecuador, 'Biodiversity Hotspot'}

Ecuador, roughly the size of the state of Colorado at $276,840 \mathrm{~km}^{2}$, is one of the most biodiverse countries in the world, containing 24 of the world's 31 principal Holdridge life zones (Holdridge 1967). Population is approximately 13.2 million with a per capita GDP of $\$ 1,959$ (USDS 2004). The Ecuadorian economy is based on petroleum production (40\% of GDP) and exports of bananas, shrimp, cut flowers and other primary agricultural products such as coffee, cacao, balsa wood, fish, and sugarcane (USDS 2004). Ecuador is the world's largest exporter of bananas (\$936.5 million in 2002) and the largest exporter of shrimp ( $\$ 251$ million in 2002) in the western hemisphere (USDS 2004). The country can be divided into four regions: the western coastal lowlands, the central Andean highlands, the eastern jungles of the Amazon Basin and - some $1000 \mathrm{~km}$ west of the mainland - the Galápagos Islands. The mainland can be divided into roughly equal thirds: the hot $\left(24-27^{\circ} \mathrm{C}\right)$ and humid western lowlands of the coastal plain (100-200 $\mathrm{km}$ wide), the temperate $\left(10-20^{\circ} \mathrm{C}\right)$ Andes mountains oriented along a north-south axis, and the tropical eastern lowlands of the Amazon basin. The country is home to over 1,600 species of birds; 90 of which are restricted-range endemics in western Ecuador, making it one of the most diverse avifaunas in the world (Wege and Long 1995; Stattersfield 1998; Ridgely and Greenfield 2001). It also harbors 20 of the 60 ardeid species found worldwide (Ridgely and Greenfield 2001; Frederick 2002). 
Coastal forests of western Ecuador have been considered one of the most threatened areas on earth due to high concentrations of endemic species and exceptional rates of habitat loss (Meyers et al. 2000). Considered one of 25 global 'biodiversity hotspots' of conservation priority, the Ecuadorian portion of the Choco/Darien/Western Ecuador Hotspot has already experienced a reduction of primary forest cover of over 95\% (Dodson and Gentry 1991; Meyers et al. 2000). This estimate was limited to data on mangrove forest loss through 1984, prior to the shrimp industry peak of the mid-1990's. Meyers et al. (2000) estimated the region to contain 9,000 species of vascular plants and 1,625 vertebrate species, $2,250(25 \%)$ and $418(26 \%)$ of which are endemic, respectively. 


\section{PROJECT SIGNIFICANCE, GOALS AND OBJECTIVES}

Research Needs and Project Significance

Little is known about colonial wading bird foraging ecology in mangroves of the Pacific coast of South America, including the Muisne River estuary in Esmeraldas, Ecuador. Further, to my knowledge, there are no detailed published accounts of wading bird use of commercial shrimp farms from anywhere in the world. This is considered a large information gap given what is already known of wading bird foraging ecology elsewhere, and the large scale of mangrove destruction that has already taken place. Additionally, since much of the biodiversity remains to be documented in various regions throughout coastal Ecuador, and development pressures upon mangrove forests there remain intense, understanding the effects of anthropogenic disturbance (i.e. construction of shrimp ponds) on vertebrate wildlife (i.e. colonial wading birds) is critical if we are to manage these systems in a sustainable fashion that continues to provide essential goods and services while providing adequate ecosystem functions (Ewel et al. 1998). Clearly, there is an urgent need for baseline biological information from these threatened ecosystems, where aquaculture provides an important source of income for many impoverished communities. Such information will not only contribute to the growing store of scientific literature, but will also assist in educating local human populations where funding, technical expertise, and political support for habitat management and conservation research is desperately needed. Additionally, my data from neotropical mangroves and aquaculture farms provides much needed information on which shrimp farmers and conservationists throughout the tropics can base land management decisions. 
Current issues include the debate over the impact of wading bird predation on cultured shrimp and the need for habitat restoration guidelines for abandoned ponds.

Data here are compared to studies examining wading bird utilization of humanmodified wetlands and estuaries throughout the world such as aquaculture ponds in the southeastern United States, fish ponds in Israel, rice fields in California, Australia, and Mediterranean Europe, tropical fish aquaculture tanks and wastewater treatment wetlands in central Florida, and nuclear power plant cooling ponds in South Carolina, among others.

Goals and Objectives

The general question addressed by my thesis research is whether commercial shrimp ponds in northwest Ecuador serve as an adequate substitute for natural mangrove mudflats as foraging habitat for a community of wading birds (Family Ardeidae). I describe and quantify the general foraging ecology of the wading bird community within the highly disturbed Muisne River estuary in Esmeraldas, Ecuador. I focus specifically on 2 species (great and snowy egret) within the community to compare habitat use, diet, and foraging efficiency, while also examining the available prey base in both shrimp ponds and natural mangrove mudflats. Specific objectives include:

1) To determine seasonal ardeid diversity, density, and distribution within both habitats,

2) To determine the diet of great and snowy egrets,

3) To compare foraging efficiency and methods of great and snowy egrets, 
4) To determine diversity, standing crop $\left(\mathrm{g} / \mathrm{m}^{2}\right)$, density, and distribution of prey items and water depths within both habitats, and

5) To determine ardeid chick diet during the breeding season.

Secondary goals include: 1) comparing site- and species-specific data with that of similar sites in the Florida Everglades and elsewhere where birds utilize artificial habitats and, 2) estimating the current level of local wading bird management efforts (e.g. scaring and shooting birds) at Ecuadorian aquaculture facilities.

Research Questions and Hypotheses

Research Questions

I want to know if the two habitat types (natural mudflats and shrimp ponds) are functionally equivalent as foraging grounds by addressing the following questions:

1) Which habitat type do the birds preferentially utilize?

2) Do great and snowy egret diets differ between species and among habitat types?

3) Do foraging efficiency and behavior of great and snowy egrets differ among habitat types?

4) Do behavior and habitat use by ardeids differ between seasons (breeding vs. non-breeding)?

5) Do prey availability (a function of standing crop, density, water depth, and species composition) and microhabitat conditions differ among habitat types? and, 
6) Which habitat type provides the greatest proportion of chick diet during the breeding season?

\section{Hypotheses}

I believe that shrimp ponds may provide a significant food subsidy for species that specialize on crustaceans (i.e. shrimp and crabs) and that they may offer superior high tide foraging grounds, but that the magnitude of the effect likely varies with species and time of year. Specific hypotheses include:

I. Wading bird density, distribution, and foraging efficiency will be a function of prey availability. Therefore I predict that:

a) Longer-legged species such as the Cocoi heron (Ardea cocoi) and great egret will forage in greater numbers and have greater foraging efficiency in shrimp ponds than shorter-legged species (see below). Additionally, these birds will forage in shrimp ponds in greater proportion than their availability across the landscape since they can utilize water as deep as $30 \mathrm{~cm}$.

b) Shorter-legged species such as the snowy egret, tricolored heron (Egretta tricolor), little blue heron (Egretta caerulea), yellow-crowned night-heron, black-crowned night-heron (Nycticorax nycticorax), and striated heron (Butorides striatus) will forage in greater numbers and have greater foraging efficiency rates in ponds with water depths $<15 \mathrm{~cm}$ and natural habitats.

c) Crustacean specialists, such as the yellow-crowned night heron (Nyctanassa violacea) and, to a lesser extent, the snowy egret, will forage in greater numbers and have greater foraging efficiency rates in shrimp ponds than in natural habitats. 
d) Abundance of prey within the estuaries will be greatest during the wet season (local ardeid breeding season) and within ponds during the last third of the shrimp growth cycle.

e) All wading birds foraging in shrimp ponds will feed in greater numbers and have greater foraging efficiency during the last third of the shrimp growth cycle (particularly during harvest events).

f) Averaged over the two sample periods (wet and dry season), and for a greater number of wading bird species, prey availability in natural habitats will be greater than in shrimp ponds.

Birds as Indicator Species

One approach to assessing the ecological effects of anthropogenic disturbance on vertebrates is the use of an indicator species, or taxonomic group of species. An indicator species is one whose presence can be used as a relative measure of a particular environmental condition (e.g. reduction of optimal foraging habitat) or biological phenomena (e.g. decreased prey abundance) that would otherwise be "too difficult, inconvenient, or expensive to measure directly" (Rolstad et al. 2000). Birds have commonly been used as ecological indicators of habitat diversity, quality, and in identifying key or target areas for biological conservation (Hoffman et al. 1994; Ogden 1994; Bancroft et al. 1997; Frederick and Spalding 1997; Rolstad et al. 2002). Relative to other vertebrates in the Americas, and especially in the neotropics, birds serve as excellent indicator species for several reasons. One is that the species-level taxonomy for birds is far better known than for any other group of plant or animal throughout the world 
(Stotz et al. 1996). Another reason is most species of birds have some level of basic biological information known about them such as field identification, relative abundance, distribution, ecology, and behavior; information which is lacking for many other taxonomic groups of organisms such as amphibians and invertebrates. Additionally, many bird species have conspicuous diurnal habits, are easily identified by non-experts, can be passively sampled by sight and sound, and show a great range of habitat utilization and specialization among species (Stotz et al. 1996). Many species are habitat or niche exclusive, and are therefore sensitive to any type of structural or spatial habitat change (e.g. fragmentation). For these and other reasons birds have become the target study species of choice to monitor many of the ecological effects of habitat disturbance throughout the Americas (Temple and Cary 1988; McGarigal and Cushman 1995, 2002; Julian and Thiollay 1996; Donovan and Lamberson 2001; Marini 2001; Bollinger and Switzer 2002; Lorenz et al. 2002; Watson 2003; Woltman 2003). However, birds should only be used as indicators of an ecological feature or process if there is a known relationship between a particular bird parameter and the environmental feature of interest (Temple and Wiens 1989).

Wading Birds as Indicators of Habitat Quality

It is accepted by various authors that wading birds can serve as effective bioindicators of environmental contamination or degradation at the suborganismal and organismal level (Kushlan 1993; Erwin and Custer 2000). However, at the population, community, and/or ecosystem level, the use of wading birds as bioindicators has been questioned by some due to the less direct relationships between the biomarker 
measurement and the ecological variable of concern at higher organizational levels (Erwin and Custer 2000).

Waterbirds of the family Ciconiiformes have been utilized as biological indicators for the ecosystem that supports them (e.g. Florida Everglades) by virtue of being primary to tertiary predators, reproductively limited by food, and colonial nesters that can be readily observed (Frederick and Spalding 1997; Frederick, P.C. and J. C. Ogden 2003). Their ecological responses can indicate environmental changes at lower trophic levels, and their large geographic ranges allow for comparisons among sites with very different environmental characteristics (Kushlan 1993). Collection of data is facilitated by their large concentrations of adults, eggs, and young at breeding and roosting colonies, social feeding habits at regular foraging areas, range of habitat utilization and specialization among species, and ease of identification by non-experts (Kushlan 1993). These characteristics lend themselves well to effective sampling of such bioindicator parameters as tissue concentration of contaminants, eggshell quality, growth rates, foraging and feeding behavior, mortality, presence/absence, distribution, and density (Kushlan 1993). A strong correlation between the initiation of their breeding activities and hydrological conditions within wetlands has also been demonstrated in the Everglades (Frederick and Spalding 1997).

At the study site near Muisne, Ecuador, several of the wading bird parameters measured are intended to "indicate" relative habitat quality within the estuary at the population level. I believe that data on wading bird species presence/absence, diversity, local colony size, size of feeding flocks, presence/absence of reproduction, prey density, prey biomass, and prey diversity are sufficient to estimate major habit differences 
between shrimp ponds and the natural estuary, thereby indirectly "indicating" the impact of shrimp farm construction on estuarine habitat quality in the area. Periodic monitoring of these same wading bird and wading bird prey base population variables could be used as a potential bioindicator of localized or landscape level changes in habitat quality or quantity.

The wading bird community at the study site is composed of the Cocoi heron, great egret, snowy egret, tricolored heron, little blue heron, cattle egret (Bubulcus ibis), striated heron, yellow-crowned night-heron, black-crowned night-heron, white ibis (Eudocimus albus) and lastly, the great blue heron (Ardea herodias) and green heron (Butorides virescens), both rare northern migrants. With the exception of the Cocoi and striated herons, these target species have been selected for study and comparisons among sites because: 1) they are colonial roosters/nesters, 2) their presence in large foraging and/or breeding aggregations indicates an adequate prey base for survival and/or reproduction, 3) they are known to breed in mangroves throughout the Americas, 4) they are known to consume shrimp throughout the Americas, and 5) they are mostly diumal. Only the great egret and snowy egret were chosen for focal behavioral observations because they represent two distinct foraging niches separated by both size and behavior. The great egret is typically a stand and wait predator ("exploiter") that may remain at foraging patches of declining quality relatively longer than the more active snowy egret (a "searcher"), which prefers to utilize high quality food patches (i.e. high prey density and low water levels $(<19 \mathrm{~cm}))$ during peak availability and has a higher giving up density of prey than the great egret (Gawlik 2002). The great egret may feed in water up to $\approx 30 \mathrm{~cm}$ deep. Snowy egrets have the broadest behavioral repertoire of all North American herons, 
commonly using walking slowly/quickly, running, hopping, and foot dragging at the study site (Parsons and Master 2000). 


\section{INTRODUCTION}

As coastal wetland ecosystems throughout the world become increasingly impacted by anthropogenic change, the need to examine the effects of this change on wading bird foraging ecology and diversity is increasing (Kushlan 1993). Wading birds are known to forage in a variety of human-modified wetlands and estuaries throughout the world. Habitat types utilized include agricultural lands (Fujioka 1998; Elphick 2000;

Fasola et al. 1996; Richardson et al. 2001), aquaculture ponds (Draulans 1988; Chu 1995; Glahn et al. 1999; Werner et al. 2000), wastewater treatment wetlands (Frederick and McGehee 1994), power plant cooling ponds (Esler 1992; Bildstein et al. 1994), coastal impoundments (Burger et al. 1982; Breininger and Smith 1990; Schikorr and Swain 1995), mitigation/restored wetlands (Murdock 1987; Coulter 1990), mining sediment ponds, eutrophied lakes, reservoirs, stormwater retention ponds, saltpans (Velasquez 1992), roadside culverts and drainage swales, golf course canals, and residential neighborhoods. Although the ecology of wading birds in both natural and humanmodified habitats in various temperate zone regions has been well documented (Kushlan 1978; Spanier 1980; Brush et al. 1986; Erwin et al. 1986; Hafner et al. 1986; Hafner 1997; Bildstein et al. 1994; Cezilly 1992; Frederick and McGehee 1994; Fasola and Ruiz 1996; Richardson et al. 2001, 2003), there is a relative paucity of parallel information from the neotropics, where wading bird diversity is greatest and coastal habitat conversion continues unabated (Meyers et al. 2000).

Historically, the dominant coastal habitat throughout the tropics has been mangrove forests (Farnsworth and Ellison 1997), an ecosystem that commonly supports the largest regional populations of breeding colonial waterbirds (Bildstein et al. 1991; 
Bildstein et al. 2002; Crozier and Gawlik 2003). These coastal wetlands offer ready access to both nesting substrate and diverse foraging habitat in freshwater marshes, brackish estuaries, and saltwater mudflats that harbor a varied prey base of euryhaline species originating in both salt and freshwater environments. However, despite the wealth of literature demonstrating the socio-economic and ecological goods and services that mangrove ecosystems offer, mangrove loss throughout the world continues at an alarming rate, with an estimated $35 \%$ of original mangrove forest cover having already been destroyed (Valiela et al. 2001). Worldwide, mariculture practices are responsible for the largest proportion (38\%) of total mangrove loss (Valiela et al. 2001).

The largest conversion of mangroves to aquaculture ponds in the Americas has occurred in the estuaries of coastal Ecuador, where over $21 \%(35,219 \mathrm{ha})$ of former mangrove habitat has been destroyed since 1984 , approximately $40 \%$ of which is attributed directly to the construction of shrimp (Penaeus vannamei) ponds (CLIRSEN 1999). The study site estuary in northwestern Ecuador has lost over $74 \%$ of former mangrove habitat to shrimp pond construction and offers a unique opportunity to examine the impacts of shrimp farming on the foraging ecology of wading birds and their prey.

Ecuador, roughly the size of the state of Colorado, is home to one of the most diverse avifaunas in the world, with over 1,600 species, including 20 of the 60 ardeid species found worldwide (Wege and Long 1995; Stattersfield 1998; Ridgely and Greenfield 2001; Frederick 2002). Coastal forests of western Ecuador are considered one of 25 global 'biodiversity hotspots' of conservation priority due to high concentrations of endemic species and exceptional rates of habitat loss (Meyers et al. 2000). Baseline information on wading bird ecology in the mangrove forests of Pacific South America is 
of particular importance for several reasons. Global concern has been raised about the negative environmental impacts and long-term sustainability of shrimp aquaculture in coastal estuaries, but few scientific studies have examined the issue (Odum and Arding 1991; Ellison and Farnsworth 1996; Gautier 2001; Jones et al. 2001). The foraging ecology of wading birds in shrimp ponds has remained undescribed in the literature, and little is known about wading bird ecology in general along the entire Pacific coast of South America. This is considered a large information gap given what is already known of wading birds elsewhere, and the large scale of mangrove destruction that has already occurred. Also, large coastal populations of wading birds in the tropics depend heavily on mangrove wetlands for nesting and foraging and numerous migratory species utilize mangroves during different seasons (Bildstein et al. 2002 and Lefebvre and Poulin 1997). The high rate of habitat loss in the region increases the urgency of understanding the ecological impacts of shrimp farming on wading birds and their prey base (Valiela et al. 2001). Additionally, many impoverished local human populations in the region depend on the goods and services provided by mangroves, further affirming the value of obtaining site-specific data to assist local wildlife managers in making land management decisions (Ewel et al. 1998; Kushlan 1997). Such information will assist habitat conservation efforts in a region where funding, technical expertise, and political support for wildlife management and conservation research is desperately needed. In addition, species composition of both wading birds and their estuarine prey base remains to be documented throughout much of coastal Ecuador.

In this study, I describe and quantify the general foraging ecology of wading birds within the highly disturbed Muisne River estuary in northwest Ecuador during the non- 
breeding and breeding season. I compare the relative suitability of commercial shrimp ponds and natural mangrove mudflats as wading bird foraging habitat by examining the foraging efficiency, diet, and behavior of great (Ardea alba) and snowy (Egretta thula) egrets, conducting flight-line counts and censuses of all wading bird species within the community, and measuring prey availability (a function of species diversity, density, standing crop, and water depth) within both habitats. Great and snowy egrets were selected for detailed study due to their contrasting foraging behavior and body size, and their large geographic ranges, which allows for comparison among study sites. The significantly larger great egret is typically a stand and wait predator ("exploiter") that may remain at foraging patches of declining quality relatively longer than the more active snowy egret ("searcher"), which prefers to utilize high quality food patches (i.e. high prey density and low water levels $(<19 \mathrm{~cm}))$ during peak availability and has a higher giving up density of prey than the great egret (Gawlik 2002). Secondary study goals include comparing site- and species-specific data with that of similar sites in south Florida and elsewhere, and estimating the current level of economic loss to shrimp farmers due to wading bird predation. 


\section{STUDY AREA AND METHODS}

\section{Study Area}

I studied wading birds in the Muisne River estuary $\left(0^{\circ} 37^{\prime} \mathrm{N}, 80^{\circ} 01^{\prime} \mathrm{W}\right)$ in Esmeraldas Province, Ecuador (Figures 1 and 2). The approximately 5000 ha estuary is included in both Conservation Internationals' Chocó-Manabí Corridor of the ChocóDarién-Western Ecuador Hotspot and Birdlife Internationals' Tumbesian Endemic Bird Area (Stattersfield 1998), and is officially recognized by the Ecuadorian Ministry of the Environment as a Wildlife Refuge. It contains riverine, fringe, basin, and overwash mangroves as well as mudflats, beaches, open water, and commercial shrimp ponds. Mangrove species include 2 species of red (Rizophora mangle and $R$. harrisonii), black (Avicennia germinans), white (Laguncularia racemosa), buttonwood (Conocarpus erectus), and smaller numbers of tea (Pelliciera rhizophora) and nato mangrove (Mora oleifera). Commercially important shellfish include black cockles (Anadara spp.), mussels (Mytilus spp.) and oysters (Crassostrea spp.). Important decapod crustaceans include blue crabs (Callinectes spp.), fiddler crabs (Uca spp.), mangrove crabs (Aratus spp.), giant land crabs (Cardisoma spp.) and shrimp (Penaeus spp., Protrachypene spp., Xiphopenaeus spp.). Common estuarine fish families include: mugilidae (mullets), centropomidae (snooks), gobiidae (gobies), soleidae (soles), paralichthyidae (flounders), ariidae (sea catfishes), gerreidae (mojarras), eleotridae (sleepers), poeciliidae (livebearers), blenniidae (blennies), syngnathid (pipefishes and seahorses), belonidae (needlefishes), sciaenids (croakers, corvinas, and weakfishes), polynemids (threadfins), engraulids (anchovies), and clupeids (menhadens). 


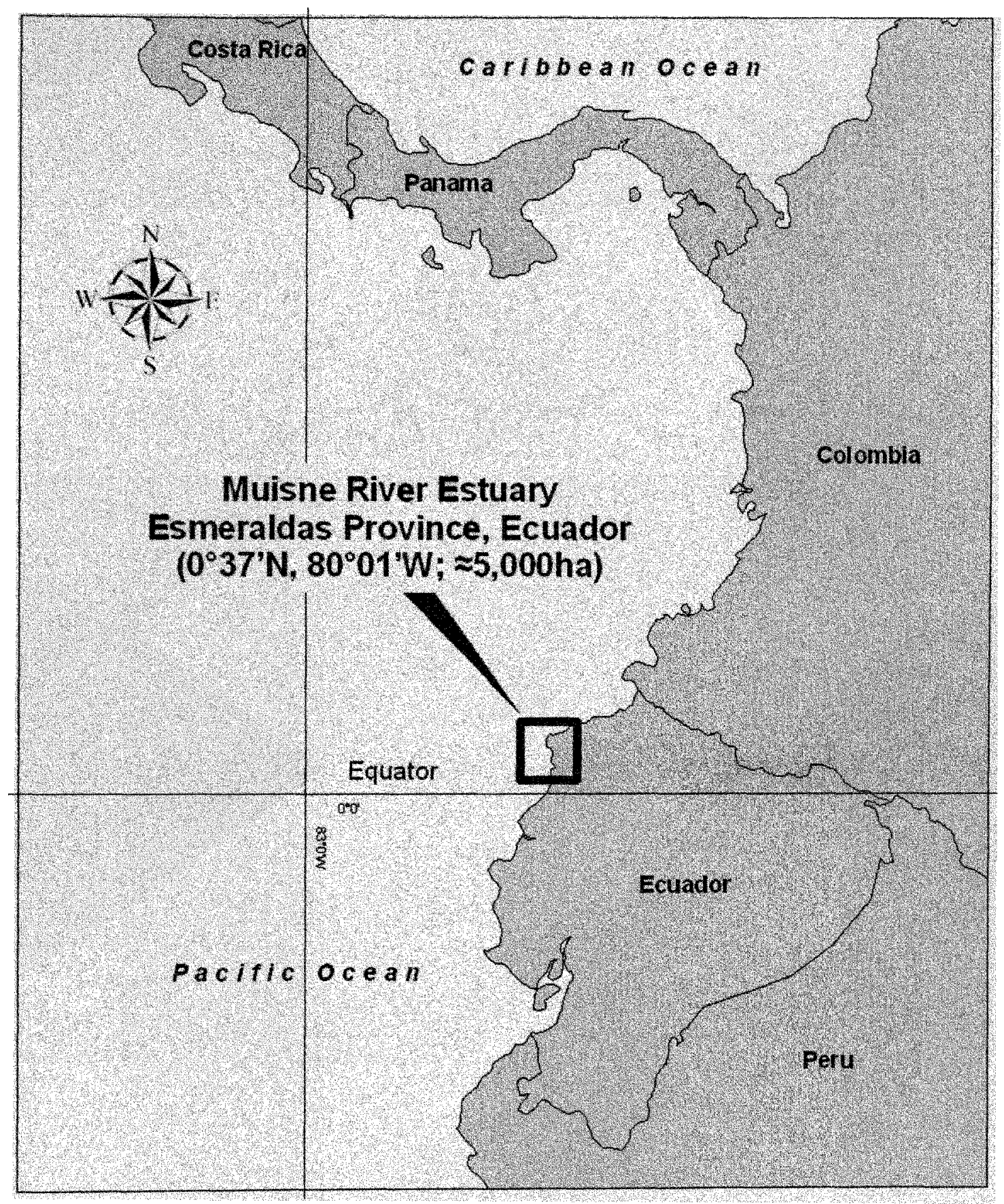

Figure 1. Study site location map (regional) \begin{tabular}{llllll}
0 & 55 & 110 & 220 & 330 & 440 \\
\hline
\end{tabular} 


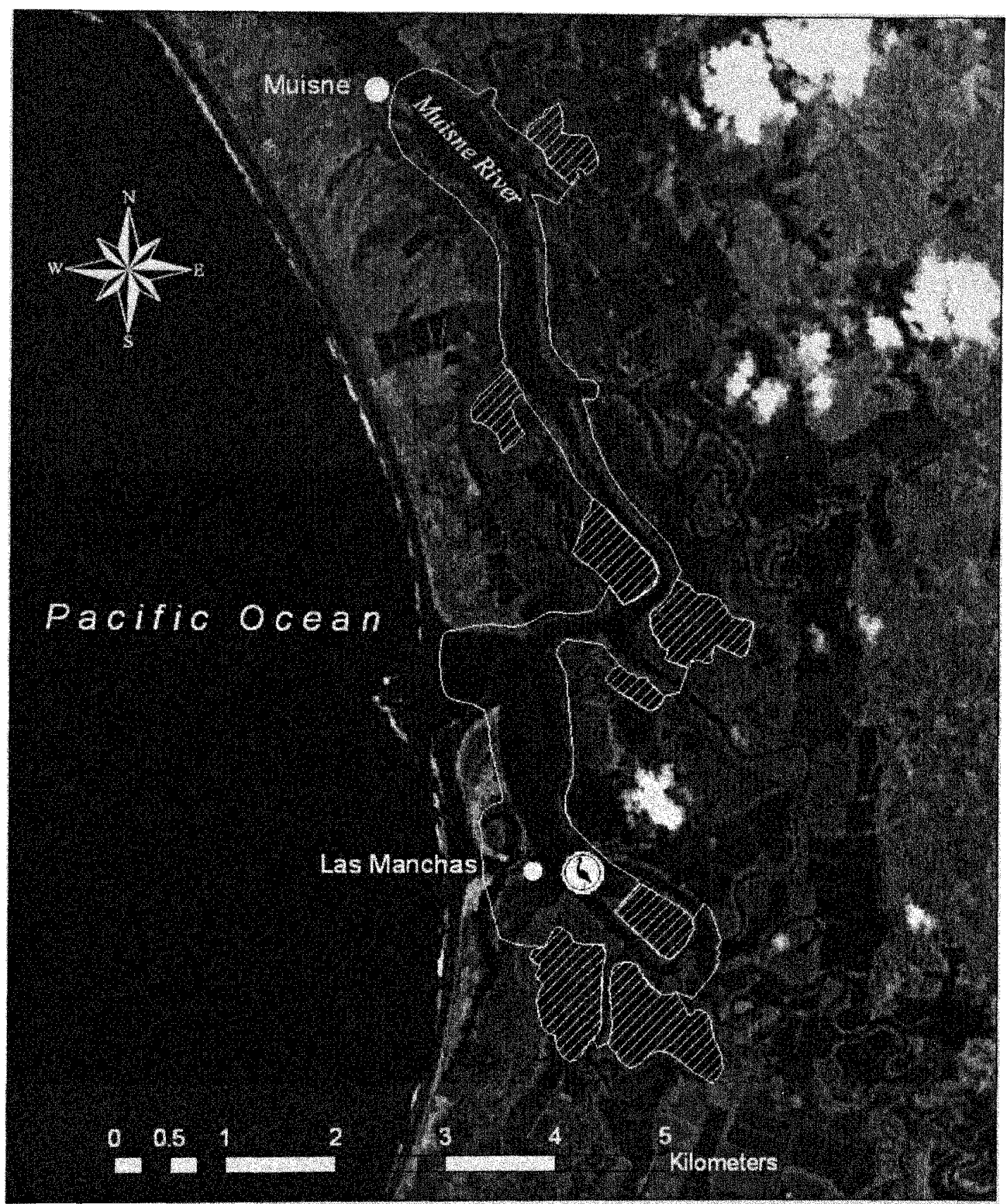

Figure 2. LANDSAT image of study site, Muisne River Estuary. Esmeraldas Province, Ecuador. Crosshatched areas indicate shimp ponds and open areas represent natural estuarine mudflats within census tansect route. Heron ic on is mixed-species wading bird colony. 
Annual mean temperature is approximately $25^{\circ} \mathrm{C}$. Precipitation averages $2.84 \mathrm{~m}$ annually, distributed somewhat unevenly ( $60 \%$ and $40 \%$, respectively) between the December through May wet season and the June through November dry season (INAMHI 2002). ENSO conditions may produce much greater rainfall on a cyclical basis in the region: $11.28 \mathrm{~m}$ of rain was recorded at the study site during the extreme "El Niño" event of 1982-3. During most years, wet season rains occur during intense thunderstorms, while most dry season precipitation falls in the form of a light rain or mist-like drizzle locally referred to as garua. Garua conditions are accompanied by a dense low elevation cloud cover that may persist for many consecutive days during the dry season, allowing for 'cloud forest' conditions to persist at relatively low elevations. Humidity is high throughout the year (mean $=83 \%$; range $71.3 \%$ (August)-87.2\%(March)), supporting abundant epiphytes (e.g. Bromeliaceae) at all elevations (Arriaga et al. 1999). The Muisne River annual average flow rate is $22 \mathrm{~m}^{3} /$ second (Carrera et al. 2001). Diurnal tidal range can be greater than $3.23 \mathrm{~m}$ (INOCAR 2004).

Mangrove forest cover within the estuary was estimated at 3282 ha in 1969 , before construction of shrimp ponds in the region. Beginning in 1993, shrimp production failures in the Gulf of Guayaquil due to Taura Syndrome prompted farmers to move to the study site and adjacent estuaries in the province of Esmeraldas in search of diseasefree environements (UNCSD 1997). As a result, the Muisne River estuary experienced one of the greatest reductions in mangrove forest cover in the country: 2,451 ha, $74 \%$ of the acreage in 1969 (CLIRSEN 1999). In 1995, 830 ha of mangrove forest remained and shrimp pond surface area covered approximately 3996 ha (CLIRSEN 1999). Since then mangrove area has shown a slight increase $(+357$ ha $)$ due to small-scale reforestation 
projects in illegally constructed ponds and natural regeneration within disturbed areas.

Adjacent upland areas are composed of cattle farms, shifting agricultural fields, secondary humid forest, and small tracts of primary humid forest which represent the last remaining parcels so far south in coastal Ecuador (Ridgely and Greenfield 2001).

The estuary is home to at least two significant mixed-species breeding colonies of wading birds. The colony studied here was comprised of great egret (Ardea alba), cattle egret (Bubulcus ibis), striated heron (Butorides striatus), tricolored heron (Egretta tricolor), little blue heron (Egretta caerulea), snowy egret (Egretta thula), yellowcrowned night heron (Nyctanassa violacea), black-crowned night heron (Nycticorax nycticorax), and cocoi heron (Ardea cocoi), as well as magnificent frigatebirds (Fregata magnificens) and neotropic cormorants (Phalacrocorax brasilianus). The colony is on a small mangrove island ( $0.7 \mathrm{ha}$ ) near the southern mouth of the Muisne river (Figure 3). The center of the island contains red and black mangroves up to $15 \mathrm{~m}$ tall. These trees are surrounded by a band of smaller even-aged white, black, and red mangroves approximately 5-6 m tall, and an outer perimeter of saplings of all three species, decreasing in size toward the river channel. The island appears to be growing toward the northwest (downstream) as evidenced by numerous seedlings extending along a large mudflat in that direction. The substrate is very soft mud and is completely submerged to a depth of approximately $20 \mathrm{~cm}$ during high tide. Breeding in the area appears to occur during the wet season from approximately late January to early May. 


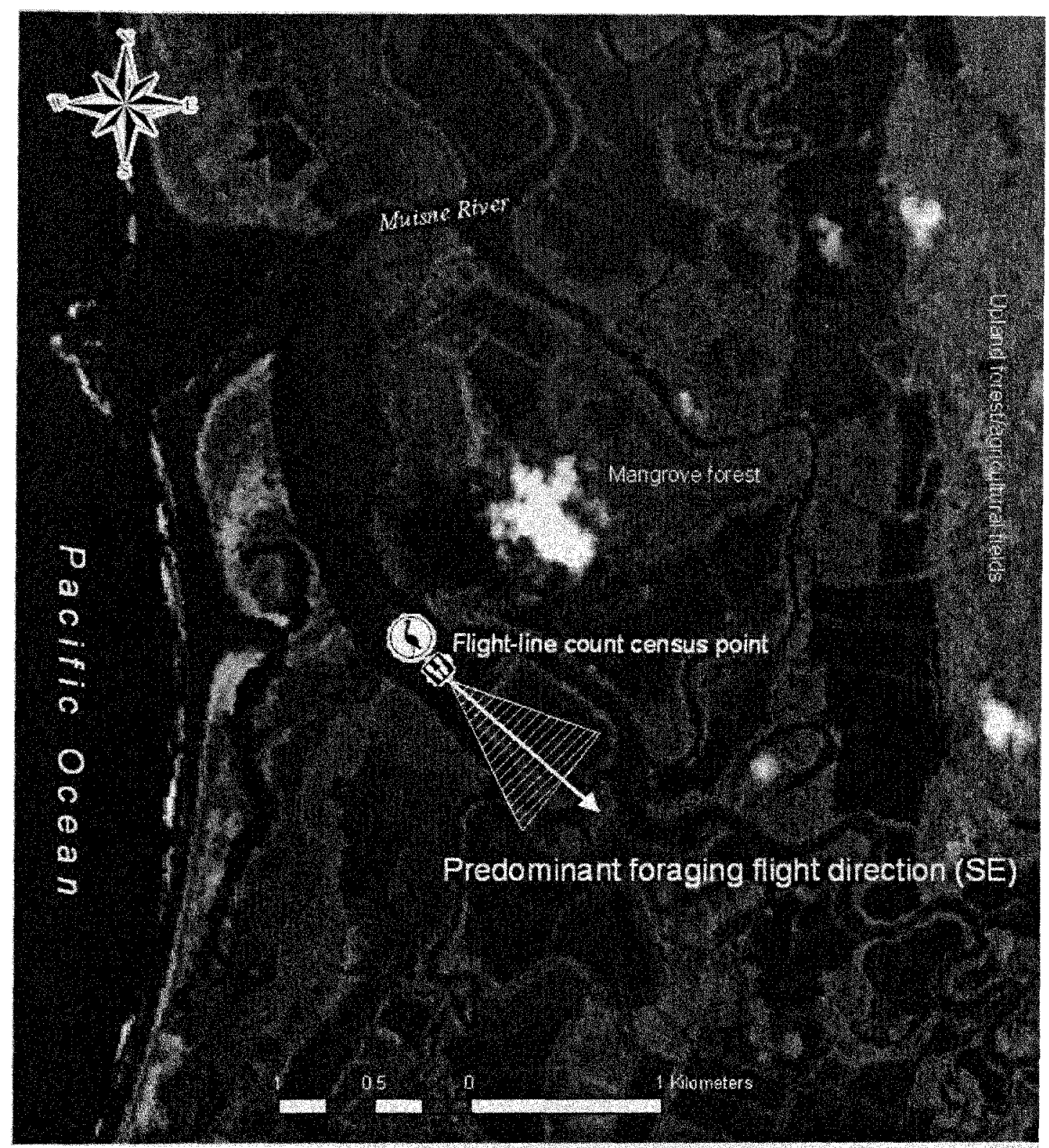

Figure 3. LANDSAT image of study site, Muisne River Estuary, Esmeraldas Province, Ecuador. Heron icon represents location of the Las Manchas mixed-species breeding colony and arrowindicates primary foraging flight direction of birds during Feb.-Mar. 2005. Darker symmetrical polygons are shrimp ponds surrounded by mangrove forest. 
Methods

The study was conducted during three field seasons: wet season 2004 (March), dry season 2004 (October and November), and wet season 2005 (February and March).

Flight-line and Nest Counts

Three morning foraging flight-line counts as described by Dusi and Dusi (1978) were conducted during the breeding (Feb.-March) season 2004, and five counts during the breeding season 2005 The colony was first circumnavigated by small boat from a distance of greater than $100 \mathrm{~m}$ in order to determine the least number of angles necessary to census the entire aggregation with $12 \times 50$ binoculars or unaided vision from a distance of greater than 80 meters. Since few birds departed to any northern headings, it was determined that a single location near the southeastern edge of the colony was an adequate vantage point from which to observe all birds departing the colony (Figure 3).

Morning counts were conducted from approximately $0610 \mathrm{~h}-0750 \mathrm{~h}$. The counts started at different times for logistical reasons and several counts ended earlier due to most birds having left the colony earlier on that particular day. Sunrise times during the counts ranged from 0621-0631h, and most birds had left the colony by approximately 0700h. Due to overcast conditions each morning, species identification was uncertain before $0610 \mathrm{~h}$, even though numerous birds left the colony prior to that time.

Data recorded included number of individuals of each species, flight direction within $200 \mathrm{~m}$ of the colony (recorded as either N, NE, E, SE, S, SW, W, or NW), and tide (recorded as low ebbing, low flooding, high flooding, or high ebbing). Skies were cloudy $(>90 \%$ cloud cover) on all survey mornings. The underlying assumptions of the flight- 
line counts are that: 1) birds are only flying to and from foraging sites and, 2) they fly directly to and from those sites in the morning and evening, with no non-foraging stops along the way during those times (Erwin 1983), 3) all roosting birds (and one individual of each breeding pair) leave the colony during the initial morning flight to foraging sites, 4) one individual of each breeding pair at the colony remains at the nest at all times during the incubation period and, 5) the number of nests did not change significantly throughout the breeding season (i.e. nesting is relatively synchronous).

Two counts of nests within the colony were conducted on 30 March 2005 by walking through the colony from northwest to southeast and using manual hand counters to tally nests by species.

\section{Estuary-wide Censuses}

The 560 ha study area included approximately 275 ha of natural mangrove estuary (mangrove forest, mudflats, sandflats/beaches, and open water) and approximately 284 ha of shrimp farms (including perimeter berms, water control structures, vegetated shorelines, and open water). Average shrimp farm size was 35.5 ha, ranging from 10.71 to 64.17 ha (Table 1). Mudflat sites were defined as locations where at least one wading bird was observed.

Wading birds were censused at 8 shrimp farms and along approximately $10 \mathrm{~km}$ of the main channel of the Muisne river on 8 days during October and November 2004 and 7 days during February and March 2005 (Figure 2). Censuses took place from 0630h to no later than $1400 \mathrm{~h}$, with most terminating by $1030 \mathrm{~h}$. The occasional presence of large 
numbers of birds at a single pond during harvest events would extend the census time length to allow for accurate counting of the foraging aggregation. The transect route was

Table 1. Estimated areas of sample locations in each habitat type (shrimp ponds and natural mudflats) within the Muisne River Estuary, Esmeraldas, Ecuador

\begin{tabular}{|c|c|c|c|}
\hline Natural mudflats & Area (ha) & Shrimp farms & Area (ha) \\
\hline Arturo & 9.38 & farm1 & 64.17 \\
\hline San Gregorio & 19.37 & farm2 & 55.82 \\
\hline Fernando Mudflat & 9.24 & farm3 & 27.30 \\
\hline La Isla & 6.01 & congal farm & 10.71 \\
\hline Las Manchas & 44.34 & farm4 & 45.40 \\
\hline Isla Bonita & 62.81 & farm5 & 38.44 \\
\hline Congal Mudflat & 8.34 & farm6 & 19.14 \\
\hline Tortuga Mudflat & 30.52 & farm7 & 23.14 \\
\hline Muisne Mudflat & 60.71 & & \\
\hline Channel North & 10.13 & & \\
\hline Channel South & 14.89 & & \\
\hline Mean & 25.1 & & 35.5 \\
\hline Total & 275.74 & Total & 284.12 \\
\hline
\end{tabular}

initiated from the town of Las Manchas each morning and counting of birds was continuous until the end of the transect length was reached near the town of Muisne at the northern mouth of the Muisne river (Figure 2). Birds were counted from either a predetermined vantage point that maximized the number of ponds visible at each shrimp farm, or from the boat along the length of the riverine transect. Birds within the estuary are habituated to daily motorboat traffic and other human activity, so birds flushing before they were recorded was not an issue. Time, tide, habitat and microhabitat type, 
species, number of individuals, foraging depth, and proximity to emergent macrophytes were recorded along the transect route. Habitat types were classified as either shrimp ponds or natural mudflats and subclassified further into microhabitat types as mudflat, sandflat, beach/rivermouth (firm sand substrate), open water, waterline (within $2 \mathrm{~m}$ of the waterline), and mangrove shoreline ( $\leq 10 \mathrm{~m}$ from mangroves). Areal extent of both shrimp ponds and natural mudflats were estimated by manually digitizing polygons over $30-\mathrm{m}$ resolution LANDSAT Thematic Mapper images of the study site and subtracting areas of open water or closed canopy mangroves using ArcGIS 9.2.

The sampling design can be thought of as a split-plot or three way mixed model ANOVA. Differences in abundances between wet season and dry season are a fixed effect, to be tested against the random effect of differences among dates within seasons. Similarly, differences between natural mudflats and shrimp ponds are a fixed effect to be tested against variation among sites within habitat types. The season by habitat interaction is thus also a fixed effect, tested against the among dates, among sites error variation. The species of birds is a fixed effect, with inferences confined to differences among those species.

The dependent variable, counts of birds of each species at each site on each date, does not meet the normality assumptions of ANOVA. Counts are expected to follow a Poisson error distribution, but initial inspection of these data revealed a large excess of zero values-- dates and sites with no individuals of a given species present. Despite a spate of recent papers on zero-inflated Poisson models in the ecological (Welsh et al. 1996, Beutel et al. 1999, Barry and Welsh 2002, Cunningham and Lindenmayer 2005, Martin et al. 2005) and environmetrics (Heilbron 1994, Hall 2000, Welsh et al. 2000, 
Dobbie and Welsh 2001, Agarwal et al. 2002, Podlich et al. 2002, Fletcher et al. 2005, Joe and Zhu 2005) literatures, software currently available to fit zero-inflated Poisson models cannot fit the 2-way mixed model of the sampling design. Even after removal of excess zeros, the counts were overdispersed relative to Poisson expectations, and negative binomial was also inadequate. Finally, nonparametric ANOVA tests cannot handle this 3 factor design.

Therefore, we took a randomization test approach to the question of differences in abundances between habitat types and seasons separately for each species. For each species, date, and site, abundances were converted to densities per hectare. The differences in average density between mudflats and shrimp ponds, and wet season and dry season were computed. Then, 11 of the 19 sites were randomly labeled mudflats, and 8 of the 14 dates were randomly labeled dry season. The fractional ranking of the differences in the real data relative to 99999 randomizations is the probability of obtaining at least that extreme of a difference in density between habitat types or seasons from the random variation among sites and dates. The SAS code implementing these randomization tests is in Appendix 1.

Wading bird diversity was calculated using Shannon's diversity index $(\mathrm{H})$ and Buza's eveness measure (E)(Hayek and Buzas 1997). The null hypothesis that the two Shannon's bird diversity indices come from habitats equal in diversity was tested with a $t$ test (Zar 1999). 
Foraging Behavior and Prey-capture Rates

Focal observations of foraging great and snowy egrets took place on 5 and 12 days during the wet seasons of 2004 and 2005 , respectively, and 12 days during the dry season of 2004. All observations of randomly selected adult foraging birds were made between $0630 \mathrm{~h}$ and $1445 \mathrm{~h}$ using $12 \times 50$ binoculars or $20 \mathrm{x}$ spotting scope from distances ranging from approximately $10-80 \mathrm{~m}$ or more (so as to minimize the affect of the observer's presence on feeding behavior). Birds were observed along the same transect route used for censusing. Individual birds were selected for observation as they were encountered on foot or by small boat and were observed for a maximum of 10 minutes or until they left the area (snowy egrets only). Individual great egrets were observed for a minimum of 10 minutes, and snowy egrets were observed for a minimum of 1 minute, due to differing foraging activity levels. However, observations of both species were divided into 1-minute intervals for data analysis. A total of 1679 observation periods (1 minute each) were conducted for great egrets (707 in natural habitats and 972 in humanmodified habitats). A total of 1725 observation periods were conducted for snowy egrets (853 in natural habitats and 872 in human-modified habitats)(Table 2). Thus, a total of 56.73 hours of focal feeding behavioral observations were conducted (i.e. $\approx 7.1$ hours per species/habitat/season). During each 1-minute observation period the following were recorded: date, time, depth, distance from emergent macrophytes and macrophyte family, number of prey-capture attempts (strikes), number of prey-captures (including genus and length of prey when possible), general feeding behavior, and microhabitat type. Water depth was estimated in relation to known tarsus lengths. Tarsus measurements from several sources were averaged for males and females of each species and are $149 \pm 16$ 
$\mathrm{mm}$ for the great egret and $94 \pm 6 \mathrm{~mm}$ for the snowy egret (Palmer 1968; Parsons and Master 2000; McCrimmon et al. 2001). A strike was recorded when the bird thrust its bill

Table 2. Focal observation sample sizes for foraging great and snowy egrets ( $N=$ total number of 1 -minute periods)

\begin{tabular}{lcccccccc} 
& \multicolumn{3}{c}{ Great egret } & & \multicolumn{3}{c}{ Snowy egret } & \\
\cline { 2 - 3 } Habitat & Wet & Dry & Total & Wet & Dry & Total & & $\begin{array}{c}\text { Total (both } \\
\text { spp.) }\end{array}$ \\
\hline Natural estuary & 408 & 299 & 707 & 480 & 373 & 853 & & 1560 \\
Shrimp ponds & 460 & 512 & 972 & 463 & 409 & 872 & & 1844 \\
\hline Total & 868 & 811 & 1679 & 943 & 782 & 1725 & 3404 \\
\hline
\end{tabular}

into water or vegetation in an apparent attempt to capture prey. Successful capture of prey was recorded when prey was manipulated in the bill followed by a distinctive swallowing movement (Hafner et al. 1982). Prey captured was identified while the bird manipulated the prey item in the bill prior to being swallowed. Prey items were classified into broad taxonomic groups (e.g. fish, crab, shrimp, insect, other) or identified to genus or species when possible. Prey length was estimated as a proportion of the species' known bill length (i.e. $1 / 4,1 / 2,3 / 4,1$, and $>1$ bill length) and expressed in increments of approximately $3 \mathrm{~cm}$ (Bayer 1985). Mean bill lengths were calculated as for tarsus lengths above and are $111 \pm 1.5 \mathrm{~mm}$ for the great egret and $81 \pm 1.4 \mathrm{~mm}$ for the snowy egret (Palmer 1968; Parsons and Master 2000; McCrimmon et al. 2001). Prey item mass was then estimated from species-specific linear regression equations created using 
measurements of prey items collected with throw traps from throughout the estuary (see Available Prey methods below). General foraging methods were recorded using the standardized nomenclature set forth by Kushlan (1978). Behavior was classified as: standing, walking slowly, walking quickly, running, hopping, foot stirring, foot dragging, dipping, probing, and pecking, or some combination of these methods. Microhabitat types were the same as those used in Estuary-wide Censuses above. If the focal bird was feeding in an unusually large feeding aggregation (e.g. such as at a shrimp pond during harvest), species composition and maximum number of individuals was recorded.

Foraging behavior and success for great and snowy egrets were analyzed with generalized linear models using SAS v9.13 PROC GENMOD, and generalized linear mixed models using the \%GLIMMIX macro from SAS Institute. For both species, the model tested for differences in the number of strikes, captures, foraging efficiency (captures/strike), and foraging method between species, season, and habitat, as well as species/season/habitat interaction effects. The errors for the strikes and captures were Poisson, while foraging efficiency had a binomial error distribution. Wading depths of foraging birds were analyzed with a single factor ANOVA using SPSS 13.0 for Windows. The program tested for differences in foraging depths by species, habitat, and season. A dietary electivity index was calculated for both great and snowy egrets following Jacobs' modification of Ivlev's Electivity Index (Jacobs 1974). 


\section{Prey Populations}

Available Prey

Available wading bird prey items were sampled with a $1-\mathrm{m}^{2}$ throw-trap (Kushlan 1981) with 1-mm mesh netting in suitable foraging areas using a stratified random sampling design. Throw trapping was conducted on 2 and 6 days during the wet seasons of 2004 and 2005, respectively, and 9 days during the dry season 2004. A total of 186 samples were taken in natural habitats ( 85 during the wet season and 101 during the dry season), and 143 in human-modified habitats (76 during the wet season and 67 during the dry season)(Table 3), totaling 329 throw-trap samples. Sampling only occurred at

Table 3. Number of throw trap samples in shrimp ponds and natural estuary by season

\begin{tabular}{lccc} 
& Wet & Dry & Total \\
\cline { 2 - 3 } Habitat & & & 186 \\
Natural estuary & 85 & 101 & 143 \\
Shrimp ponds & 76 & 67 & \\
\hline Total & & & 329 \\
\hline
\end{tabular}

locations where estuary or pond water depths were $<30 \mathrm{~cm}$, the maximum foraging depth of the largest target species, the great egret (Powell 1987). Estuarine prey was sampled along the same transect route used for censusing. Pilot data collected in March 2004 was used to determine the number and location of permanent sampling stations necessary to accurately represent prey populations at the study site based on substrate type, vegetative 
cover, salinity, water depth, and the logistics of accessing the area. Three replicate samples were taken at each permanent sample station $(\mathrm{N}=12)$, with each throw attempting to represent a shallow $(<10 \mathrm{~cm})$, medium $(10-20 \mathrm{~cm})$, and deep $(20-30 \mathrm{~cm})$ water microhabitat (Figure 4). Several temporary sample locations were sampled along the transect route during pilot data collection and were pooled with all other stations for data analysis. Data collected from each throw trap included date, time, location, habitat, microhabitat, tide, water depth, salinity, prey item species, length and mass, distance from emergent macrophytes and macrophyte family, and age of stocked shrimp (shrimp ponds only). Turbidity was initially considered an important variable affecting prey availability, but was not measured because visibility was greater than $40 \mathrm{~cm}$ in both habitat types in all throw trap samples. Dissolved oxygen was also considered an important factor affecting prey availability initially, but no evidence of Aquatic Surface Respiration (ASR) was observed in either habitat type and so was not likely affecting prey availability through altered prey behavior. Prey was collected from the throw trap with a $0.95-\mathrm{m}^{2}$ seine passed through the water column within the trap until three consecutive passes yielded no prey items. Five additional sweeps with a small dipnet yielding no prey concluded a replicate sample. Prey items sampled were counted, identified (digital photographs taken if necessary), measured for total length and mass with a mm scale and Pesola balance, and released. Five individuals of each prey type captured from all habitats were collected and stored in $75 \%$ ethanol to serve as voucher specimens for identification. From this density (number of individuals $/ \mathrm{m}^{2}$ ), standing crop $\left(\mathrm{g} / \mathrm{m}^{2}\right)$, species diversity, and water depth were estimated. Habitat and microhabitat types were as defined in Estuary-wide Censuses above. 


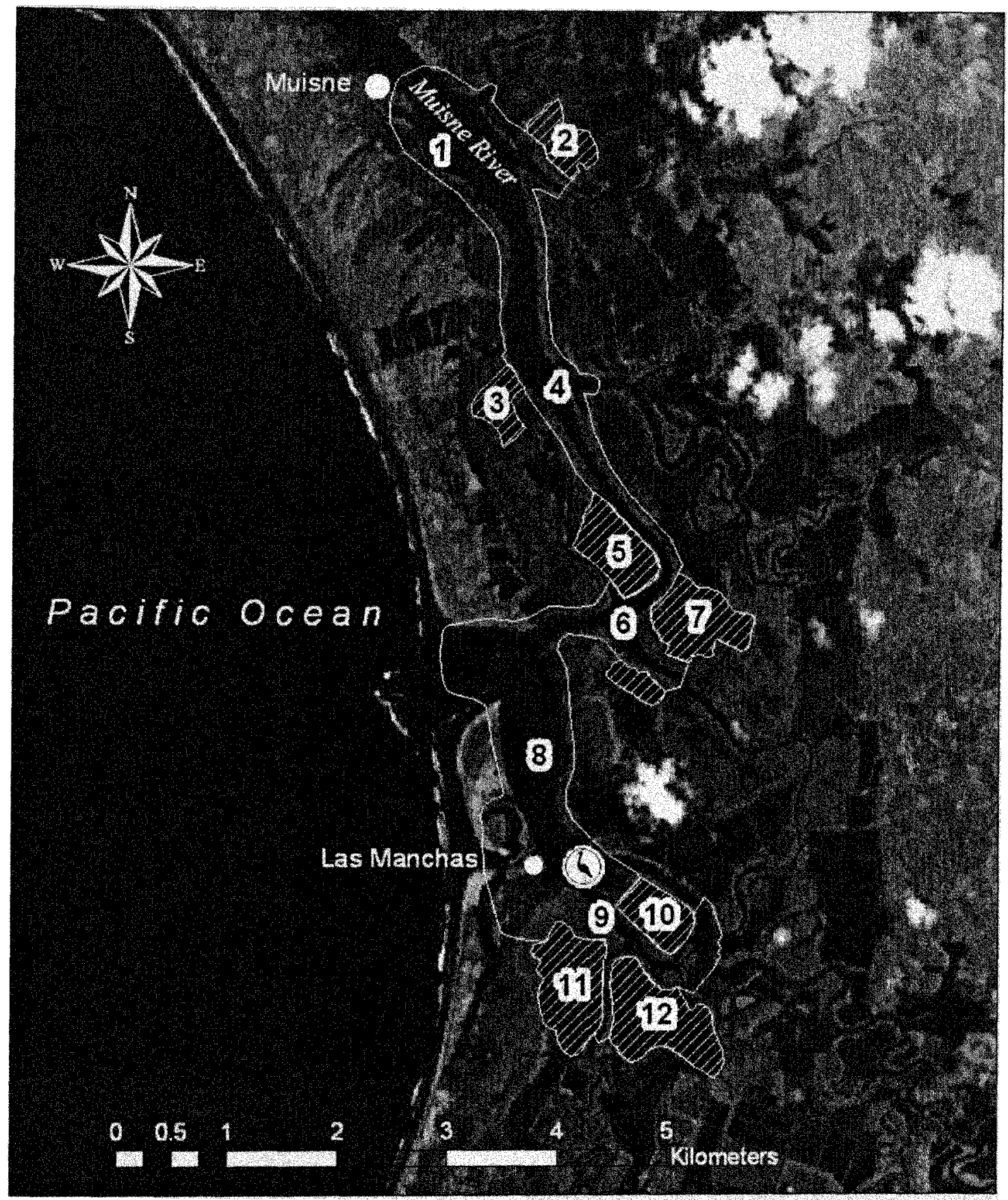

Figure 4. Throw trap sampling station locations $(1=12)$ within the Musne River Estuary, Esmeraldas Province. Ecuador (LANDAT image. background). Crosshatched areas represent sample stations within shimp ponds and open areas represent stations within natual estury. 
Prey base data were analyzed with single factor ANOVAs using SPSS 13.0 for

Windows. The program tested for differences in density, standing crop, mean length and mass of prey items, depth, and salinity by habitat and season. Age of stocked shrimp in ponds was deleted from the data analysis due to small sample sizes of representative ages during each season. Prey species diversity was calculated using Shannon's diversity index $(\mathrm{H})$ and Buza's eveness measure (E)(Hayek and Buzas 1997). The null hypothesis that the two Shannon's prey diversity indices come from habitats and seasons equal in diversity was tested with $t$ tests (Zar 1999).

Nestling Regurgitates

During the breeding season of 2005 (23 March-30 March), great and snowy egret diets were examined by collecting nestling ( $>1$ week old) regurgitates from nests within the colony. Fifty-one boluses were examined for species composition and length and mass of prey items $(\mathrm{N}=506)$. Boluses were stored in $70 \%$ ethanol for later processing. I was unable to collect great egret boluses directly from their nests because they were placed on small lateral branches in the crowns of the tallest black and red mangrove trees near the center of the island and were too difficult to access by climbing. The three great egret boluses collected were seen falling from their nests and were collected from the mud below. Although cocoi herons were observed entering the colony with nesting material, no nests were observed and were most likely built in the vicinity of the great egret nests in the tops of the tallest trees. Most little blue heron, tricolored heron, and snowy egret nests were placed approximately $2-3.5 \mathrm{~m}$ high in black and white mangroves 
$(5-8 \mathrm{~cm} \mathrm{dbh})$. Yellow and black-crowned night herons nested in the same trees at heights ranging from 3-5 meters. 


\section{RESULTS}

\section{Flight-line Counts}

The mean number of individuals counted each morning was 2383 , with a range from 283 on 23 February 2005 to a maximum of 3343 on 12 March 2005. Utilizing nest counts, average daily proportions of each species leaving the colony, and the maximum daily total observed, it was estimated that approximately 1168 snowy egrets, 1044 cattle egrets, 378 little blue herons, 301 black-crowned night herons, 207 tricolored herons, 133 great egrets, 98 yellow-crowned night herons, 10 cocoi herons, and 4 striated herons utilized the colony. Of these, an estimated 1323 birds were non-breeders. A total of 1010 nests were counted at the colony, indicating that approximately $60.4 \%$ of roosting birds were nesting, including approximately 40 great egret pairs and 353 snowy egret pairs (Table 4). Skies were cloudy ( $>90 \%$ cloud cover) on all survey mornings. Eight morning flight-line counts indicated that most birds $(>98 \%)$ flew toward the southeast after departing the breeding colony. The remaining birds were observed flying either to the northeast, east, south, southwest, or west. No birds were observed departing the colony to the north. Small sample size and lack of tidal range during sample days prevented analysis of the influence of tide on the number of birds leaving the colony and the direction of their foraging flights.

\section{Estuary-wide Censuses}

Daily counts of birds by species and site are tabulated in Appendix 2. The mean observed densities of all wading bird species combined were $50 \%$ greater at natural mudflats than at shrimp ponds $\left(25.6 / \mathrm{km}^{2}\right.$ v. $\left.17.8 / \mathrm{km}^{2}\right)$, and greater in the dry season than 
Table 4. Estimated number of wading birds utilizing the Las Manchas Colony, Esmeraldas, Ecuador during February-March 2005.

\begin{tabular}{|c|c|c|c|}
\hline & $\begin{array}{c}\text { Number of } \\
\text { breeding pairs }\end{array}$ & $\begin{array}{c}\text { Number of } \\
\text { non-breeders }\end{array}$ & $\begin{array}{c}\text { Total number of } \\
\text { individuals in colony }\end{array}$ \\
\hline \multicolumn{4}{|l|}{ Species $(N=9)$} \\
\hline Great egret & 40 & 53 & 133 \\
\hline Cattle egret & 315 & 414 & 1044 \\
\hline Striated heron & 1 & 2 & 4 \\
\hline Tricolored heron & 62 & 83 & 207 \\
\hline Little blue heron & 114 & 150 & 378 \\
\hline Snowy egret & 353 & 462 & 1168 \\
\hline Yellow-crowned night heron & 30 & 38 & 98 \\
\hline Black-crowned night heron & 91 & 119 & 301 \\
\hline Cocoi heron & 4 & 2 & 10 \\
\hline Total & 1010 & 1323 & 3343 \\
\hline
\end{tabular}

Note: Approximately $60.4 \%$ of colony residents were nesting in 2005.

the wet season $\left(27.4 / \mathrm{km}^{2}\right.$ v. $\left.16.0 / \mathrm{km}^{2}\right)$ (Table 5 and 6$)$. However, these differences were not significantly greater than expected given the variation among sites and among dates ( $\mathrm{p}_{\text {habitat }}=.849 ; \mathrm{p}_{\text {season }}=.237 ; \mathrm{p}_{\text {interaction }}=.120$ ). The two best mudflats averaged 112.6 and 91.4 birds per census date, while two other mudflats averaged 0.14 and 0.36 birds per census, and the other mudflats averaged from .71 to 4.29 birds per census. The highest average count for a shrimp pond was 100.7 , driven by a single dry-season observation of 1169 birds in one day during a harvesting event. The lowest average birds per day for a shrimp pond was 0.14 . The daily averages of the other 6 shrimp ponds ranged from 1.93 to 15.2 birds. Shrimp ponds were clearly frequented by more birds than the worst 
mudflat sites; the best mudflats may have attracted more birds than the best shrimp ponds. Day to day variation in abundances was similarly large: ranging from 56 total birds on the lowest wet season census date to 1550 on the highest dry season date.

The same pattern of day to day and site to site variation masking differences between seasons and habitat types held for each individual species, with the exception of great egrets. Significantly more great egrets were observed in the dry season than the wet season ( 11.6 per site per day v. 1.9 per site per day, $\mathrm{p}=0.005$ ). While the difference in densities between habitat types was not significant, there was a large and significant season by habitat interaction ( $\mathrm{p}=0.00036$ for densities): very few great egrets were observed in shrimp ponds during the wet season.

Table 5. Mean density (individuals $/ \mathrm{km} 2$ ) of wading birds in shrimp ponds and natural mudflats within the Muisne River Estuary, Esmeraldas, Ecuador.

\begin{tabular}{lccc} 
& Wet season & Dry season & Mean total \\
\cline { 2 - 3 } Habitat & & & $25.6(\max .59 .1)$ \\
Natural mudflats & 27.3 & 23.8 & $17.8(\max .77)$ \\
Shrimp ponds & 4.7 & 30.9 & \\
\hline Mean Total & $16(\max .36)$ & $27.4(\max .96 .1)$ & \\
\hline
\end{tabular}


Table 6. Peak density (individuals $/ \mathrm{km} 2$ ) of wading birds in shrimp ponds and natural mudflats within the Muisne River Estuary, Esmeraldas, Ecuador compared with similar values measured at other wading bird study sites.

Density

Location Reference

Habitat type

(birds/km2)

Northwestern Italy

Fasola, M. 1986

Rice fields

13.3

River

3.8

Canals

13.4

Marsh

Central Japan

Lane, S. and M. Fujioka

Rice fields

58.2

Freestone County, Texas

Esler, D. 1992

Power plant cooling reservoir (Main lake)

6.1

Power plant cooling reservoir (Hot lake)

East-central Florida

Coastal impoundments

Central Florida

Frederick, P. and M. McGehee

Wastewater treatment wetland (Iron Bridge site)

53.6

1994

Wastewater treatment wetland (Mulberry)

Natural freshwater marsh

South Florida

Hoffman et al. 1990

Central Everglades (freshwater wetlands)

South Florida

Sykes, P. and G. Hunter 1978

Flooded agricultural fields

Southwest Florida

Jelks 1991

Freshwater wetlands (Ringling/Mcarthur Preserve)

Coastal Honduras

Frederick, P. et al. 1997

Coastal wetlands (La Mosquitia)

Coastal Nicaragua

Frederick, P. et al.1997

Coastal wetlands (Miskito Coast)

Southwestern Venezuela

Morales, G. and J. Pacheco 1986

Llanos (diked freshwater wetlands)

Llanos (natural freshwater wetlands)

Muisne River Estuary, This study

Shrimp pond

145.8

Esmeraldas, Ecuador

Mangrove estuary

63.8

Southeastern Australia

Richardson, A. and I. Taylor 2005 Rice fields 
Foraging Microhabitats and Methods

Microhabitat types

Fifty three percent $(53.5 \%)$ of all birds recorded were observed foraging in shrimp farms, and the remaining $46.5 \%$ within the natural estuary (Table 7). Eighty five percent $(85.2 \%)$ of all great egrets observed were foraging in shrimp ponds, while the remaining $14.8 \%$ of great egrets were observed in natural mudflats. Combining both habitats, $40.5 \%$ of great egret observations took place in shrimp pond mudflats, $35.1 \%$ on shrimp pond shorelines, $13.3 \%$ along the waterline of natural mudflats, $8.6 \%$ in open water of shrimp ponds, and rarely near shrimp pond water control structures $(<1 \%)$, beaches/rivermouths,

Table 7. Percentages of each species observed in each habitat type during census surveys within the Muisne River Estuary, Ecuador.

\begin{tabular}{lcc} 
& Natural mudflats & Shrimp ponds \\
\cline { 2 - 3 } Species & $(\%)$ & $(\%)$ \\
\hline Great egret & 14.8 & 85.2 \\
Striated heron & 57.4 & 42.6 \\
Tricolored heron & 87.1 & 12.9 \\
Little blue heron & 74.3 & 25.7 \\
Snowy egret & 44.6 & 55.4 \\
Yellow-crowned night heron & 78.6 & 21.4 \\
Black-crowned night heron & 0.0 & 100.0 \\
Cocoi heron & 50.0 & 50.0 \\
& & \\
\hline Total & 46.5 & 53.5 \\
\hline
\end{tabular}


mangrove shorelines, estuarine open water, and sandflats $(<1 \%$ each)(Figure 5). Fifty five percent $(55.4 \%)$ of all snowy egrets observed were foraging in shrimp ponds, while natural habitats accounted for $44.6 \%$ of all snowy egret observations. Combining both habitats, $41.1 \%$ of snowy egret observations were on natural mudflats, $34.9 \%$ on pond mudflats, $17.5 \%$ along pond shorelines, $3 \%$ in open water within ponds, $1.3 \%$ along mangrove shorelines, $1.1 \%$ at the natural mudflat waterline, and rarely in open water, sandflats, or near water control structures $(<1 \%$ each)(Figure 5). Most observations of little blue, tricolored, and yellow-crowned night herons were made in natural mudflats (i.e. greater than $74 \%$ of each species' total counts) (Table 7). Striated herons were also observed more often in natural habitats $(57.1 \%)$ than in shrimp ponds $(42.9 \%)$. Cocoi herons, white ibis, and black-crowned night herons were all observed irregularly in both habitat types in very small numbers $(<10$ individuals each). Black crowned night herons and cocoi herons are highly nocturnal at the site and were excluded from the analysis. All white ibis observed were immature and were considered uncommon at the site.

The most common microhabitat type utilized by all species combined was natural mudflats $(40.3 \%)$, followed by shrimp pond mudflats (29.4\%), shrimp pond shorelines (18.4\%), and to a much lesser extent, open water in shrimp ponds (4.8\%), natural mudflat waterlines $(3.9 \%)$, mangrove shorelines $(1.8 \%)$, sandflats $(0.6 \%)$, water control structures $(0.4 \%)$, estuarine open water $(0.3 \%)$, and beach/rivermouth $(0.1 \%)$ (Figure 6$)$.

Ninety four percent $(94.1 \%)$ of all great egrets observed in both habitats combined foraged $>20 \mathrm{~m}$ from emergent aquatic or woody vegetation. Small proportions of great egrets were found foraging from emergent mangrove stumps within shrimp ponds $(3.1 \%)$, or adjacent to mixed Poaceae/buttonwood (1.8\%), mixed red, black, and 


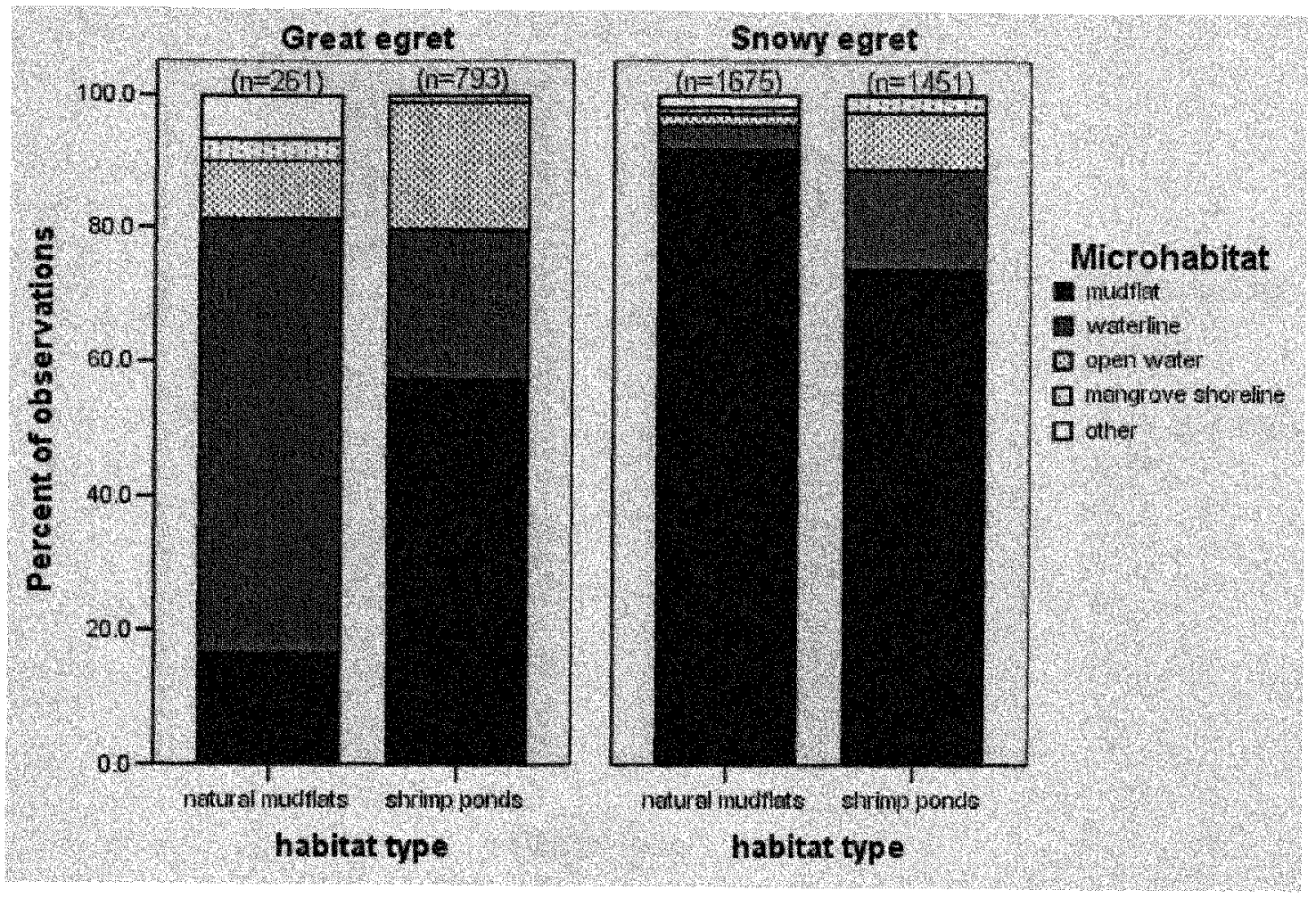

Figure 5. Microhabitats utilized by great and snowy egrets in the Muisne River Estuary, Ecuador.

white mangroves $(0.6 \%)$, black mangroves $(0.2 \%)$, Eleocharis sp. $(0.1 \%)$, or red mangrove $(0.1 \%)$. Most great egrets that foraged near vegetation were perched on the vegetation itself ( $70 \%$ ), while the remaining $30 \%$ were an average of $0.79 \mathrm{~m}$ from the nearest vegetation.

Most snowy egrets in both habitats combined also foraged $>20 \mathrm{~m}$ from emergent vegetation $(96.4 \%)$, with the remaining $3.6 \%$ of birds foraging from stumps within shrimp ponds $(1.9 \%)$, mixed red, black, and white mangroves $(1.1 \%)$, black mangroves $(0.1 \%)$, red mangroves $(0.2 \%)$, and Poaceae $(0.1 \%)$. Of these, most foraged $2.5 \mathrm{~m}$ from 


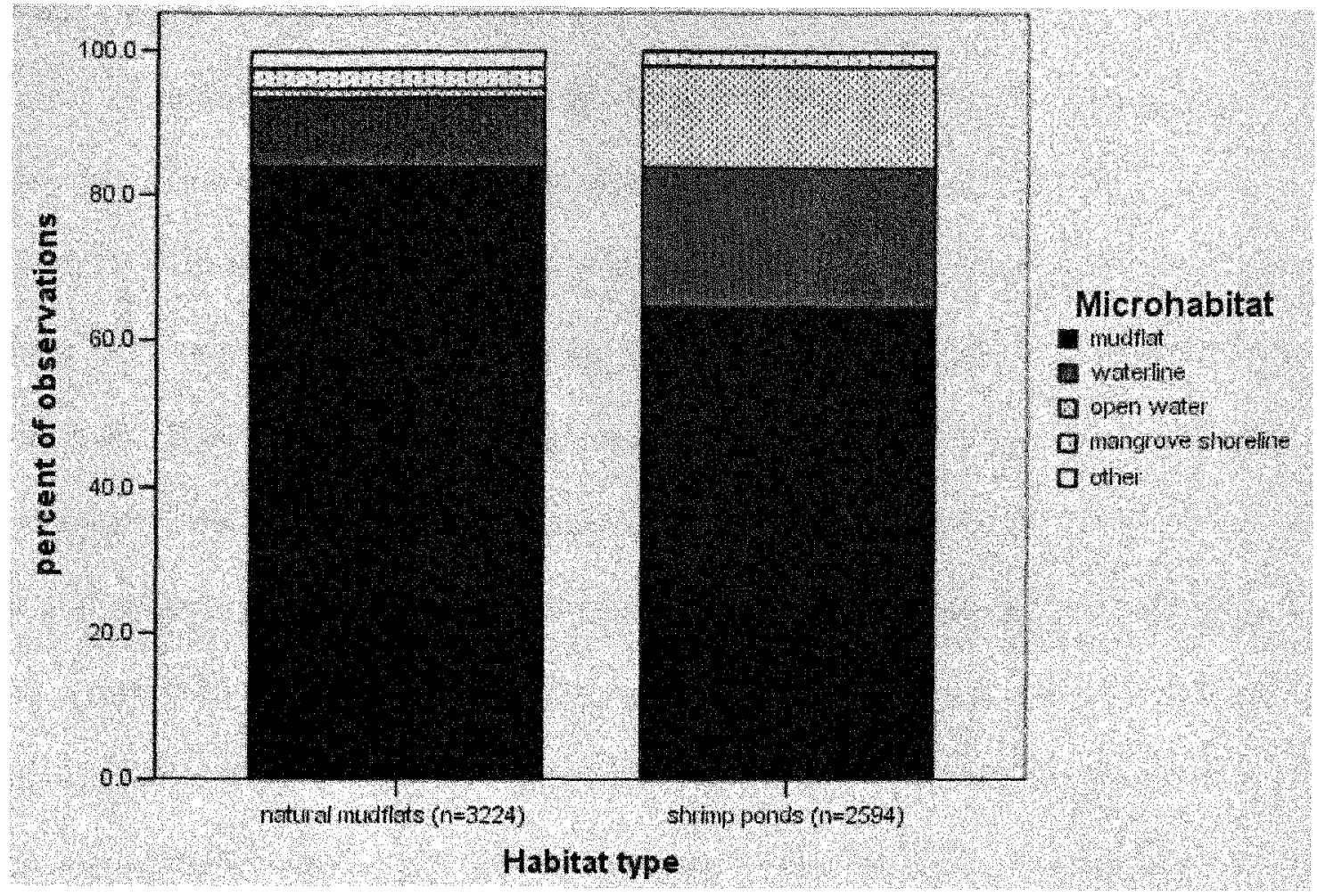

Figure 6. Microhabitat types utilized by all wading bird species during both seasons in the Muisne River Estuary, Ecuador.

the nearest vegetation. Most little blue herons $(92.8 \%)$, tricolored herons $(94.9 \%)$, and yellow-crowned night herons $(94.3 \%)$ all foraged $>20 \mathrm{~m}$ from yellow-crowned night herons $(94.3 \%)$ all foraged $>20 \mathrm{~m}$ from emergent vegetation. Due to their small size, semi-cryptic coloration, and known foraging association with vegetation, striated herons were omitted from this summary. 


\section{Water Depths}

Mean foraging depths used by great egrets $(5.2 \mathrm{~cm})$ were significantly greater than that of snowy egrets $(0.8 \mathrm{~cm})$ in both habitats combined $(\mathrm{df}=1, \mathrm{~F}=859.7$, $\mathrm{p}<0.0001)($ Table 8). Mean foraging depth for the great egret in natural mudflats $(9.5 \mathrm{~cm}$, range $0-21 \mathrm{~cm})$ was significantly greater than in shrimp ponds $(3.9 \mathrm{~cm}$, range $0-30 \mathrm{~cm})$ $(\mathrm{df}=1, \mathrm{~F}=128.9, \mathrm{p}$-value $<0.0001)$. The reverse was true of all other species within the community, which foraged at significantly greater depths in shrimp ponds than in the natural estuary. Mean water depth for foraging snowy egrets was $0.8 \mathrm{~cm}$, averaging 0.4 $\mathrm{cm}$ (range $0-15 \mathrm{~cm}$ ) in natural mudflats and $1.2 \mathrm{~cm}$ (range $0-24 \mathrm{~cm}$ ) in shrimp ponds $(\mathrm{df}=1, \mathrm{~F}=71.0, \mathrm{p}$-value $<0.0001)$. Mean water depth for foraging little blue herons was 0.7 $\mathrm{cm}$, averaging $0.2 \mathrm{~cm}$ (range $0-12 \mathrm{~cm}$ ) in natural habitats and $2.1 \mathrm{~cm}$ (range $0-15 \mathrm{~cm}$ ) in shrimp ponds $(\mathrm{df}=1, \mathrm{~F}=171.1$, $\mathrm{p}$-value $<0.0001)$. Mean foraging depth for tricolored herons was $1.2 \mathrm{~cm}$, averaging $0.9 \mathrm{~cm}$ (range $0-12 \mathrm{~cm}$ ) in natural areas and $3.2 \mathrm{~cm}$ (range 0-12 cm) in shrimp farms $(\mathrm{df}=1, \mathrm{~F}=26.2, \mathrm{p}$-value $<0.0001)$. Mean foraging depth for yellow-crowned night herons was $1.1 \mathrm{~cm}$, averaging $0.3 \mathrm{~cm}$ (range $0-9 \mathrm{~cm}$ ) in natural habitats and $4.2 \mathrm{~cm}$ (range $0-15 \mathrm{~cm}$ ) in shrimp farms $(\mathrm{df}=1, \mathrm{~F}=84.22$, $\mathrm{p}$-value $<0.0001$ ). All striated herons were observed feeding over relatively deep water from dry perches on woody vegetation or water control structures.

\section{Foraging methods}

Foraging methods utilized by great egrets differed significantly by habitat, season, and habitat $x$ season interaction $\left(\mathrm{df}=2, x^{2}=33.74, \mathrm{p}<.0001, \mathrm{df}=4, x^{2}=37.77, \mathrm{p}<0.0001\right.$, and $\left.\mathrm{df}=2, x^{2}=65.18, \mathrm{p}<.0001\right)$. Foraging methods utilized by snowy egrets differed 
Table 8. Average foraging depth $(\mathrm{cm})$ recorded for wading birds in shrimp ponds and mudflats in the Muisne River Estuary, Ecuador.

\begin{tabular}{|c|c|c|c|}
\hline \multirow{2}{*}{ Species } & Natural mudflats & Shrimp ponds & \multirow[b]{2}{*}{ Total (mean) } \\
\hline & & & \\
\hline Great egret & 9.52 & 3.91 & 5.15 \\
\hline Tricolored heron & 0.94 & 3.16 & 1.23 \\
\hline Little blue heron & 0.18 & 2.12 & 0.68 \\
\hline Snowy egret & 0.41 & 1.15 & 0.78 \\
\hline Yellow-crowned night heron & 0.28 & 4.17 & 1.11 \\
\hline Cocoi heron & 7.5 & 10.50 & 9.00 \\
\hline Total (mean) & 1.13 & 2.18 & 1.63 \\
\hline
\end{tabular}

Note: foraging depths for all species were significantly different between habitat types p-value $<.05$

significantly by habitat, season, and habitat $\mathrm{x}$ season interaction $\left(\mathrm{df}=5, x^{2}=150.35\right.$, $\mathrm{p}<.0001, \mathrm{df}=6, x^{2}=68.17, \mathrm{p}<0.0001$, and $\left.\mathrm{df}=5, x^{2}=57.99, \mathrm{p}<.0001\right)$. Foraging methods of all species combined differed significantly between species, habitat, and season ( $\mathrm{df}=6$, $x^{2}=60.51, \mathrm{p}<.0001, \mathrm{df}=5, x^{2}=27.28, \mathrm{p}<.0001$, and $\left.\mathrm{df}=6, x^{2}=18.94, \mathrm{p}<.0043\right)$. There was a significant season $\mathrm{x}$ habitat interaction with respect to foraging methods of all species combined $\left(\mathrm{df}=5, x^{2}=26.16, \mathrm{p}<.0001\right)$.

The most common foraging behavior for great egrets in shrimp ponds was a combination of standing and walking slowly (77.5\%), followed by walking slowly only $(14.4 \%)$, standing only (5.9\%), and a combination of walking quickly and walking slowly or standing (2.2\%)(Table 9). Great egrets employed a wider variety of foraging methods 
in the natural estuary where they most often fed by walking slowly (43.7\%), a combination of walking slowly and standing (28.9\%), standing only (14.9\%), a combination of walking quickly and walking slowly (10.5\%), walking quickly only $(1.4 \%)$, and hopping $(0.4 \%)$.

Snowy egrets utilized a much greater diversity of foraging methods in both habitat types than did the great egret (Table 10). In shrimp ponds the most commonly used technique was walking slowly and probing in exposed mud (51.3\%), followed by walking slowly (26\%), standing $(11.7 \%)$, walking quickly (8.7\%), probing (1.4\%), running and standing $(0.5 \%)$, foot-stirring $(0.5 \%)$, and hopping and walking slowly $(0.1 \%)$. Snowy egrets in natural habitat foraged mostly by walking quickly (39.3\%), walking slowly $(38.1 \%)$, standing $(21.4 \%)$, and combinations of foot-stirring with other techniques $(1.1 \%)$.

Table 9. Percentages of each foraging method utilized by great egrets in each habitat type within the Muisne River Estuary, Ecuador.

\begin{tabular}{lccc} 
& Natural mudflats & Shrimp ponds \\
\cline { 2 - 3 } Foraging method & $(\%)$ & $(\%)$ \\
\hline walking slowly & 43.7 & 14.4 \\
standing/walking slowly & 28.9 & 77.5 \\
standing & 14.9 & 5.9 \\
walking quickly/slowly & 10.6 & - \\
walking quickly & 1.5 & - \\
hopping & 0.4 & - \\
combination of above & - & 2.2 \\
& & 100.0 \\
\hline Total & 100.0 &
\end{tabular}


Table 10. Percentages of each foraging method utilized by snowy egrets in each habitat type within the Muisne River Estuary, Ecuador.

\begin{tabular}{lccc} 
& Natural mudflats & Shrimp ponds \\
\cline { 2 - 3 } Foraging method & $(\%)$ & $(\%)$ \\
\hline walking slowly and probing & 38.2 & 51.3 \\
walking slowly & 21.4 & 26.0 \\
standing & 39.3 & 11.6 \\
walking quickly & - & 8.6 \\
probing & - & 1.4 \\
running and standing & 1.1 & 0.5 \\
foot stirring & - & 0.5 \\
hopping and walking slowly & & 0.1 \\
& 100.0 & \\
\hline Total & & 100.0 \\
\hline
\end{tabular}

Prey-capture Rates

Strike, capture, and foraging efficiency rates were significantly different between great and snowy egrets $(\mathrm{df}=1, \mathrm{~F}=557.5, \mathrm{p}<.0001, \mathrm{~F}=341.6, \mathrm{p}<.000, \mathrm{~F}=89.3, \mathrm{p}<.0001$, respectively). The number of strikes/minute differed significantly by species, season, and habitat $\left(\mathrm{df}=1, x^{2}=5976.3, \mathrm{p}<.0001, x^{2}=137.4, \mathrm{p}<.0001, x^{2}=5042.8, \mathrm{p}<.0001\right)$. The number of captures/minute differed significantly by species and habitat, but not season $(\mathrm{df}=1$, $x^{2}=1545.2, \mathrm{p}<.0001, x^{2}=1674.9, \mathrm{p}<.0001$ ). Foraging efficiency (captures/strikes) differed significantly by species, season, and habitat $\left(\mathrm{df}=1, x^{2}=79, \mathrm{p}<.0001, x^{2}=96, \mathrm{p}<.0001\right.$, $\left.x^{2}=17.5, \mathrm{p}<.0001\right)$. Interaction effects between species and season, species and habitat, and season and habitat differed significantly with respect to the number of strikes, 
captures, and foraging efficiencies of feeding birds $\left(\mathrm{df}=1, x^{2}=11.7, \mathrm{p}<.0006, x^{2}=20.3\right.$, $\left.\mathrm{p}<.0001, x^{2}=10.7, \mathrm{p}<.0011\right)$.

Strike and capture rates were significantly higher in the natural estuary than in shrimp ponds for both great and snowy egrets in all sampling periods except the dry season $\left(\mathrm{df}=1, x^{2}=261.58, \mathrm{p}<.0001\right.$ and $x^{2}=183.58, \mathrm{p}<.0001$, respectively)(Table 11, Figures 7 and 8). Mean strike and capture rates for great egrets in shrimp ponds during the dry season were 0.3 strikes/minute and 0.16 captures/minute, respectively. In the same habitat during the wet season, rates were 0.20 strikes/minute and 0.11 captures/minute. Mean strike and capture rates for great egrets on natural mudflats during the dry season was 0.27 strikes/minute and 0.09 captures/minute, respectively. In the same habitat during the wet season, rates were 0.61 strikes/minute and 0.35 captures/minute. Mean seasonal rates for the great egret were 0.29 strikes/minute and 0.14 captures/minute during the dry season, and 0.39 strikes/minute and 0.22 captures/minute during the wet season.

Mean strike and capture rates for snowy egrets in shrimp ponds during the dry season was 1.09 strikes/minute and 0.31 captures/minute, respectively. In the same habitat during the wet season, rates were 0.90 strikes/minute and 0.19 captures/minute. Mean strike and capture rates for snowy egrets on natural mudflats during the dry season was 7.46 strikes/minute and 2.88 captures/minute, respectively. In the same habitat during the wet season, rates were 9.19 strikes/minute and 2.35 captures/minute. Mean seasonal rates for the snowy egret were 4.12 strikes/minute and 1.53 captures/minute during the dry season, and 5.12 strikes/minute and 1.29 captures/minute during the wet season. 
Table 11. Strike, capture, and efficiency rates of great and snowy egrets foraging in shrimp ponds and natural mudflats within the Muisne River Estuary, Ecuador compared with similar values measured at other wading bird study sites.

\section{GREAT EGRET}

\begin{tabular}{|c|c|c|c|c|c|}
\hline Study location & Habitat type & $\begin{array}{l}\text { Total minutes } \\
\text { of observation }\end{array}$ & $\begin{array}{l}\text { Mean strike rate } \\
\text { (strikes/min.) }\end{array}$ & $\begin{array}{l}\text { Mean capture rate } \\
\text { (captures/min.) }\end{array}$ & $\begin{array}{l}\text { Mean efficiency } \\
\text { (captures/strike) }\end{array}$ \\
\hline $\begin{array}{l}\text { Muisne River Estuary, Ecuador } \\
\text { This study }\end{array}$ & mangrove estuary & 1679 & 0.34 & 0.18 & 0.56 \\
\hline $\begin{array}{l}\text { San Francisco Bay, California } \\
\text { Horn, C. } 1983\end{array}$ & saltmarsh & 4038 & 0.53 & 0.35 & 0.666 \\
\hline $\begin{array}{l}\text { Southern New South Wales, Australia } \\
\text { Richardson, et al. } 2001\end{array}$ & rice fields & 300 & 0.6 & 0.3 & 0.56 \\
\hline $\begin{array}{l}\text { Tampa Bay, Florida } \\
\text { Rogers, J. } 1983\end{array}$ & mangrove estuary & 919 & 0.9 & 0.21 & 0.233 \\
\hline $\begin{array}{l}\text { Sacramento Valley, California } \\
\text { Elphick, C. } 2004\end{array}$ & rice fields & 310 & 0.72 & 0.8 & 0.67 \\
\hline $\begin{array}{l}\text { New York City, New York } \\
\text { Maccarone, A. and K. Parsons } 1994\end{array}$ & $\begin{array}{l}\text { freshwater pond } \\
\text { estuarine wetland }\end{array}$ & - & - & $\begin{array}{l}0.34 \\
0.27\end{array}$ & $\begin{array}{c}0.56 \\
0.4\end{array}$ \\
\hline $\begin{array}{l}\text { New York City, NY and Wichita, Kansas } \\
\text { Maccarone, A. and J. Brzorad } 2002\end{array}$ & $\begin{array}{l}\text { tidal estuaries (NY) } \\
\text { FW lakes and ponds (KS) }\end{array}$ & $\begin{array}{l}1374 \\
1374\end{array}$ & $\begin{array}{l}1.27 \\
0.52\end{array}$ & $\begin{array}{l}0.69 \\
0.27\end{array}$ & $\begin{array}{l}0.55 \\
0.51\end{array}$ \\
\hline
\end{tabular}


Table 11, continued. Strike, capture, and efficiency rates of great and snowy egrets foraging in shrimp ponds and natural mudflats within the Muisne River Estuary, Ecuador compared with similar values measured at other wading bird study sites.

\section{SNOWY EGRET}

Study location and author(s)

\section{Habitat type}

Muisne River Estuary, Ecuador

This study

San Francisco Bay, California

Horn, C. 1983

Tampa Bay, Florida

Rogers, J. 1983

New York City, New York

Maccarone, A. and K. Parson 1994

New York City, NY and Wichita, Kansas

Maccarone, A. and J. Brzorad 2002

Tampa Bay, Florida

Kent, D. 1986

Tampa Bay, Florida mangrove estuary

saltmarsh

mangrove estuary

freshwater pond

estuarine wetland

tidal estuary (NY)

FW lakes and ponds (KS)

estuary

estuary
425

.04

0.497

Total minutes

1725

3726

1.87

0.96

tures/min.)

Mean efficiency

(strikes/min.)

1.40

0.34

0.34

.45

0.25

$\begin{array}{llll}1201 & 3.12 & 1.03 & 0.33\end{array}$

$\begin{array}{llll}1201 & 3.29 & 1.61 & 0.49\end{array}$

909

0.428

0.369 


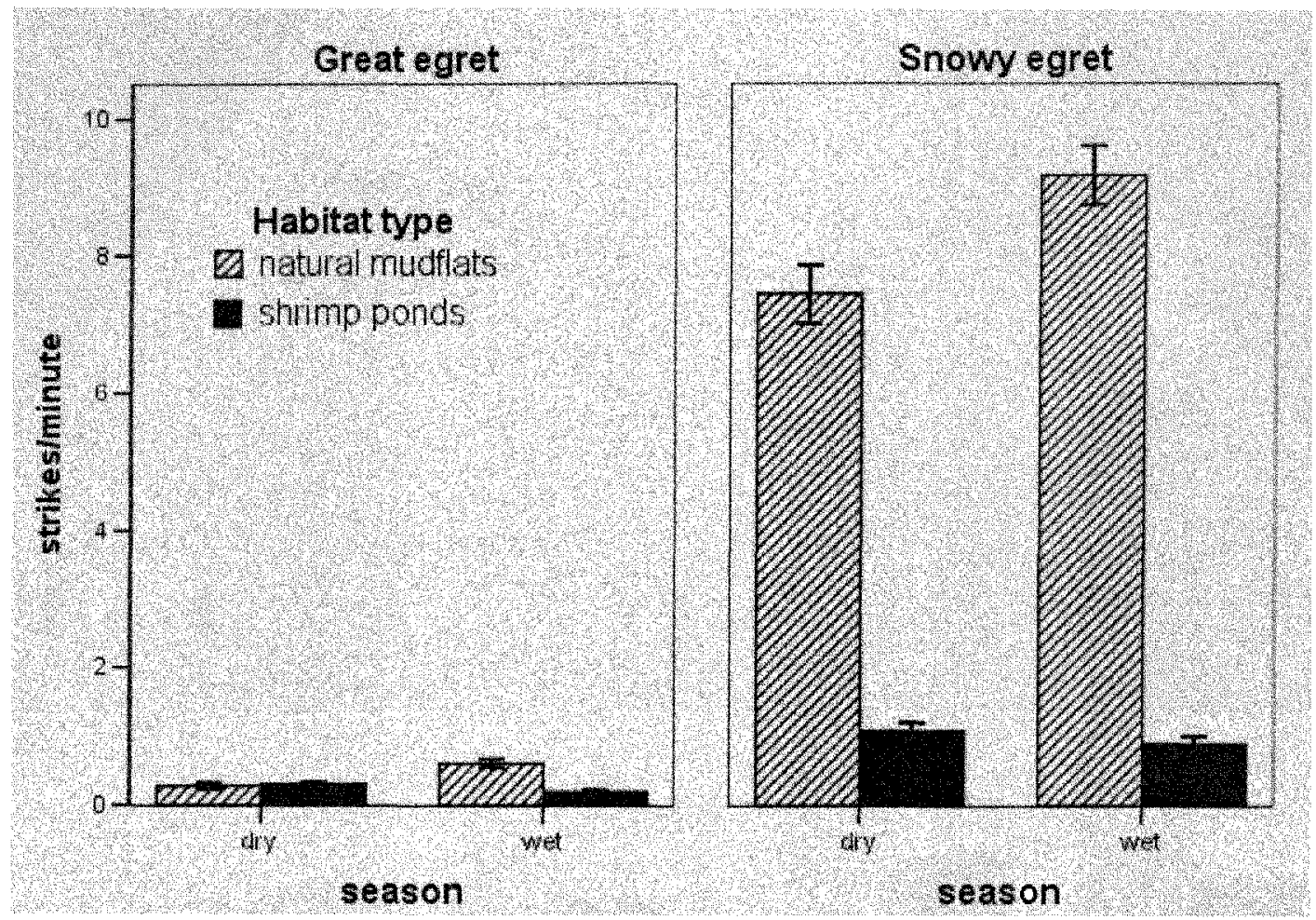

Figure 7. Mean number of strikes/minute for great and snowy egrets in the Muisne River Estuary, Ecuador.

Error bars: $+1-1.00 \mathrm{SE}$

Mean capture efficiency (captures/strikes) for great egrets was significantly greater in shrimp ponds $(\hat{u}=58.3 \%)$ than in the natural estuary $(\hat{u}=52.9 \%)$ (Table 11 and Figure 9). The opposite was true of snowy egrets, where capture efficiency was significantly greater in natural mudflats $(\hat{u}=34.0 \%)$ than in shrimp ponds $(\hat{u}=33.0 \%)$.

Species Diversity

Diversity of foraging birds in both habitats differed only slightly. There were 9 species of wading bird present in the shrimp ponds and 8 observed in natural mudflats, where the black-crowned night heron was not observed. All other species were present in 


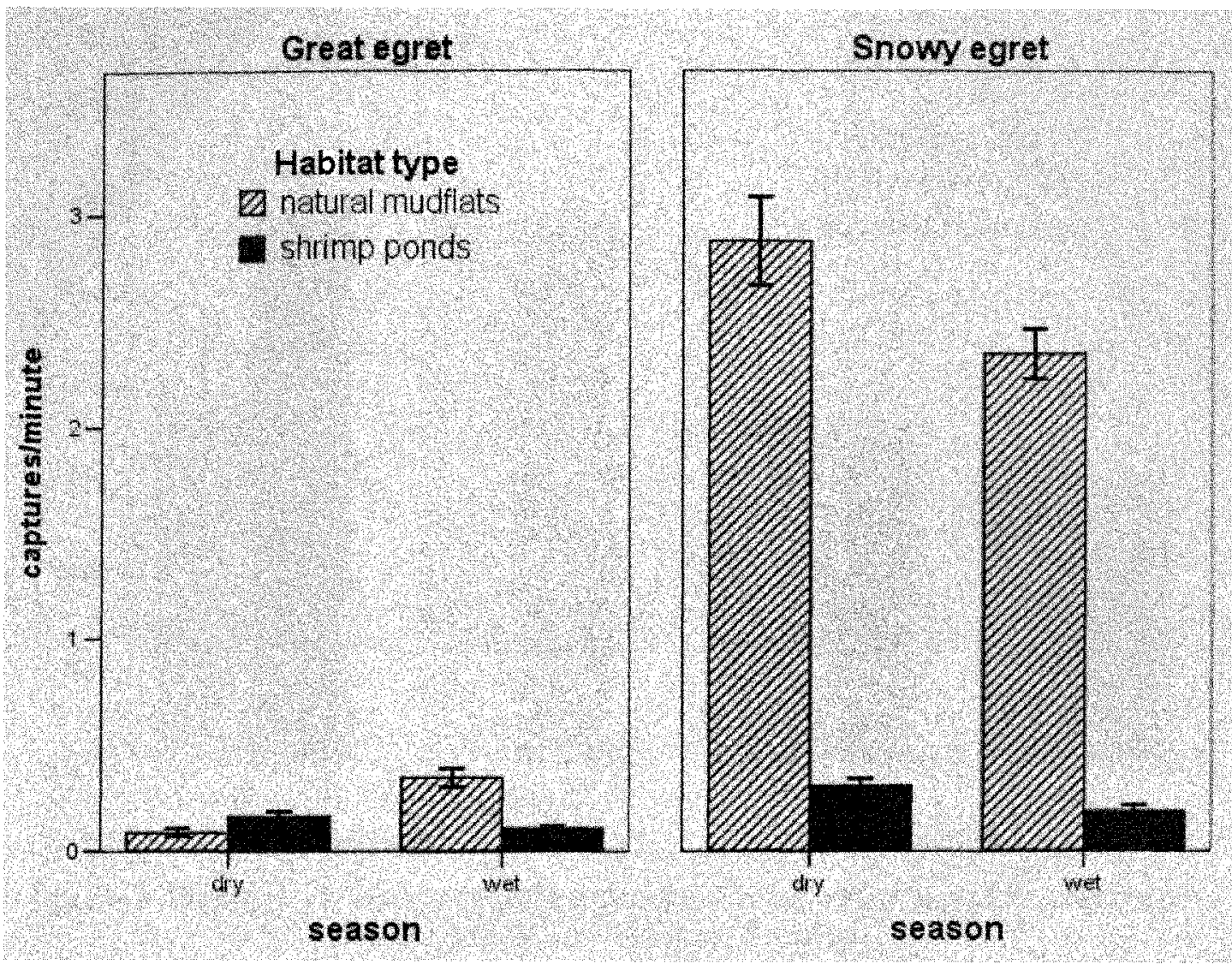

Figure 8 . Mean number of captures/minute by great and snowy egrets in the Muisne River Estuary, Ecuador.

Error bars: +1-1.00 SE

both habitats. Shrimp ponds had a Shannon's H=1.1066 and a Buza's eveness measure of $\mathrm{E}=0.3360$. The natural estuary had a Shannon's $\mathrm{H}=1.2818$ and a Buza's eveness measure of $E=0.4505$. Shannon's diversity indices were not significantly different between habitats.

Prey items Captured

Both great and snowy egrets captured significantly larger prey items (in both 


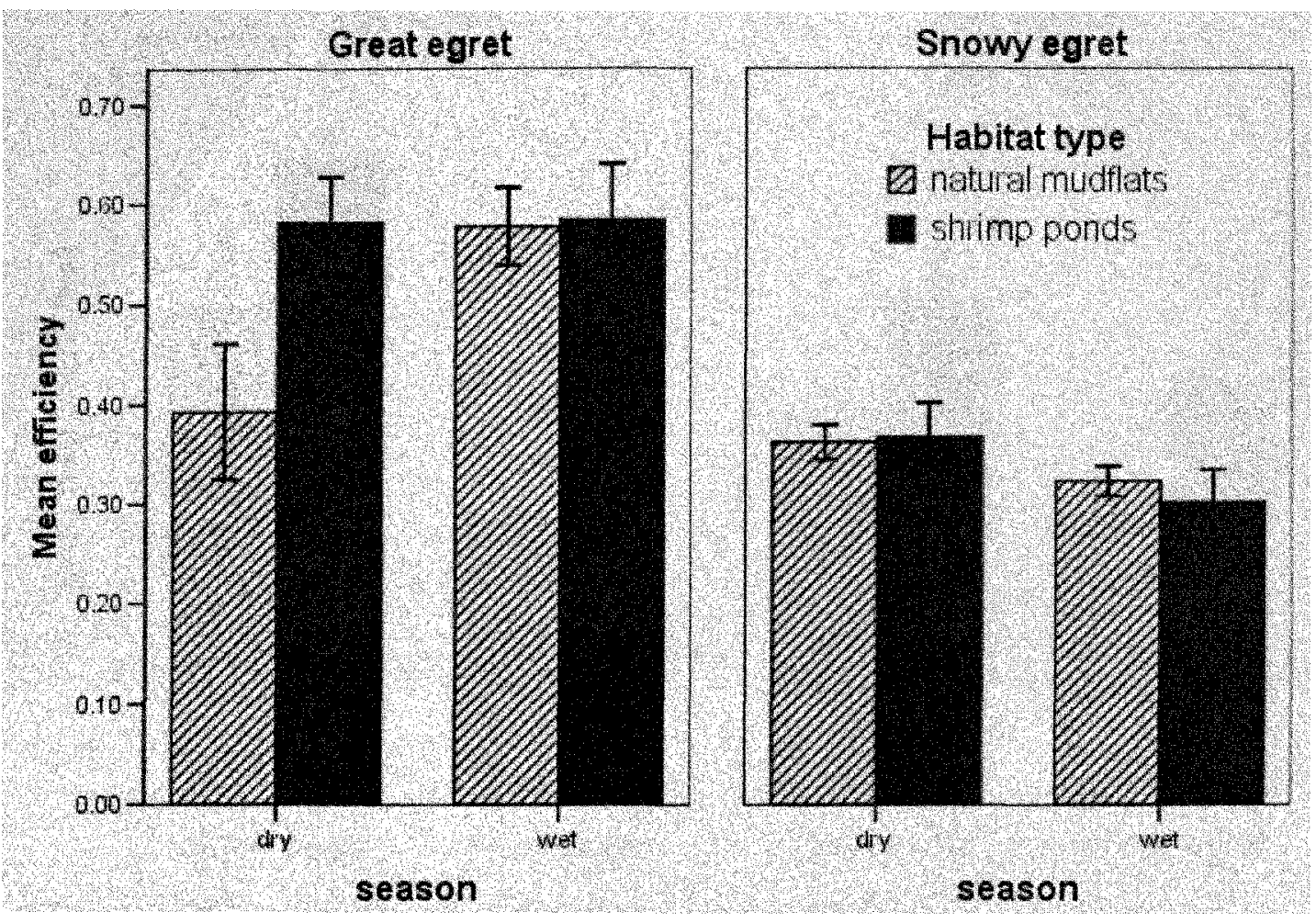

Figure 9. Capture efficiency (captures/strikes) for great and snowy egrets in the Muisne River Estuary, Ecuador.

Error bars: $+1-1.00 \mathrm{SE}$

length and mass) in shrimp ponds than in the natural estuary $(\mathrm{df}=1, \mathrm{~F}=283.2, \mathrm{P}<0.0001$, and $\mathrm{F}=45.8, \mathrm{P}<0.0001$ )(Figures 10 and 11 ). Great egret prey items from shrimp ponds averaged $3.58 \mathrm{~g}$ and measured $6.4 \mathrm{~cm}$, while prey items from the natural estuary averaged $2.21 \mathrm{~g}$ and measured $4.47 \mathrm{~cm}$. Snowy egret prey items from shrimp ponds averaged 1.19 $\mathrm{g}$ and measured $4.7 \mathrm{~cm}$, while items from the natural estuary averaged $0.23 \mathrm{~g}$ and measured $3.09 \mathrm{~cm}$. Great egrets captured significantly larger prey items on average than snowy egrets (mass $=3.01 \mathrm{~g}$ and length $=5.52 \mathrm{~cm}$ versus mass $=0.39 \mathrm{~g}$ and length $=3.38 \mathrm{~cm}$; $\mathrm{df}=1, \mathrm{~F}=228.6, \mathrm{P}<.0001$ and $\mathrm{F}=81.1, \mathrm{P}<.0001$, respectively). 


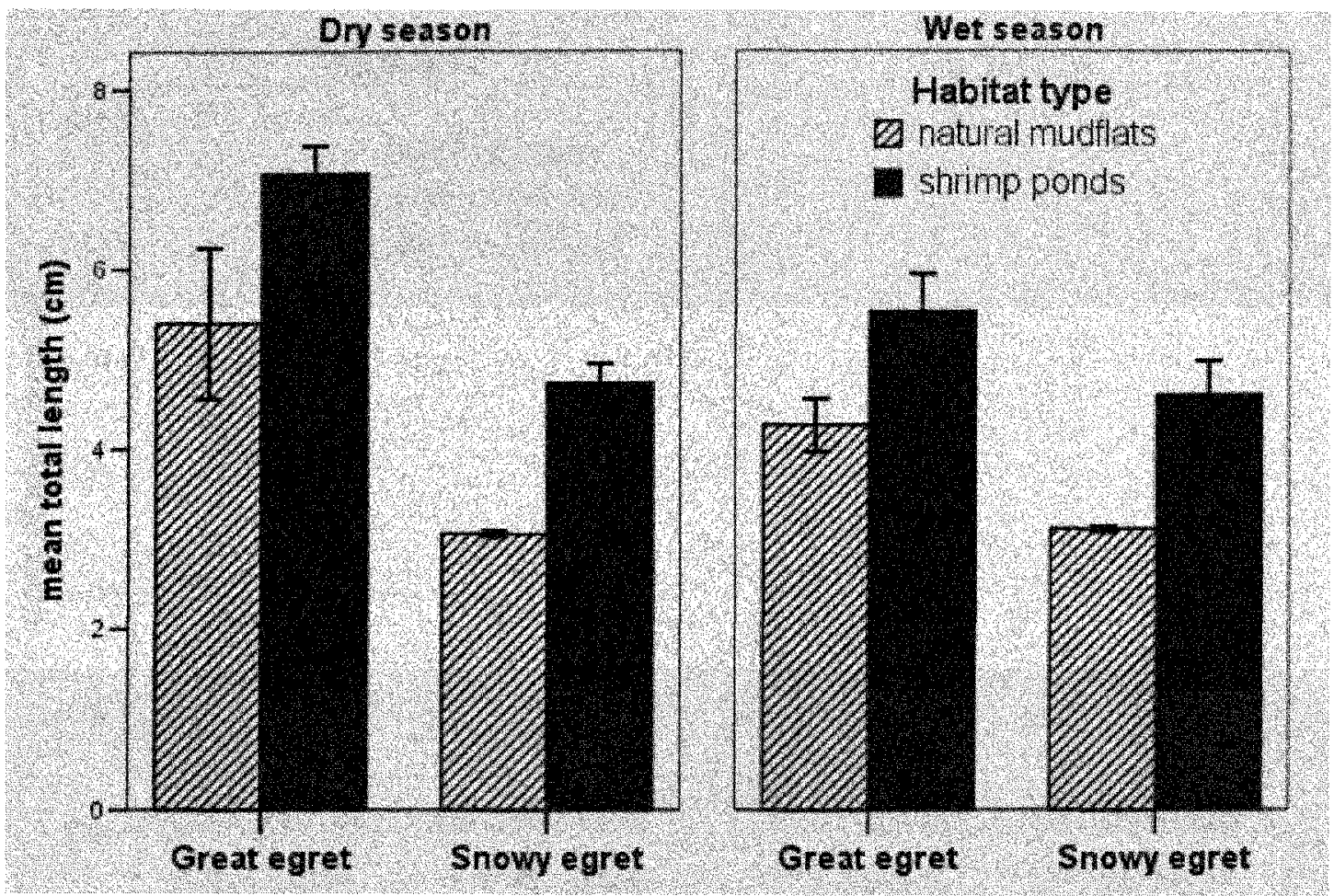

Figure 10. Mean total length of prey items captured by great and snowy egrets in the Muisne River Estuary, Ecuador.

*All prey items were observed during focal observation of foraging birds or were found in nestling boluses

Error bars: $+1-1.00 \mathrm{SE}$

Based on focal observations, the most common prey items for the great egret in both habitats were shrimp (41.6\% Penaeus vannamei), fish of the family Gobiidae $(35.3 \%$, of which $45.0 \%$ were Ctenogobius sagittula, $37.4 \%$ undetermined Gobiidae, $13.6 \%$ Gobionellus liolepis, and 4.0\% Gobionellus microdon), unidentified fish ( $2.1 \%)$, white mullet (9.7\% Mugil curema), oval flounder ( $9.0 \%$ Syacium ovale), and small numbers of Pacific fat sleepers (1.4\% Dormitator latifrons) and 'millonarios' (1.4\% Profundulus punctatus)(Figure 12 and Table 11). Snowy egret prey items were dominated by fish of the family Gobiidae $(80.8 \%$, of which $80.8 \%$ were undetermined 


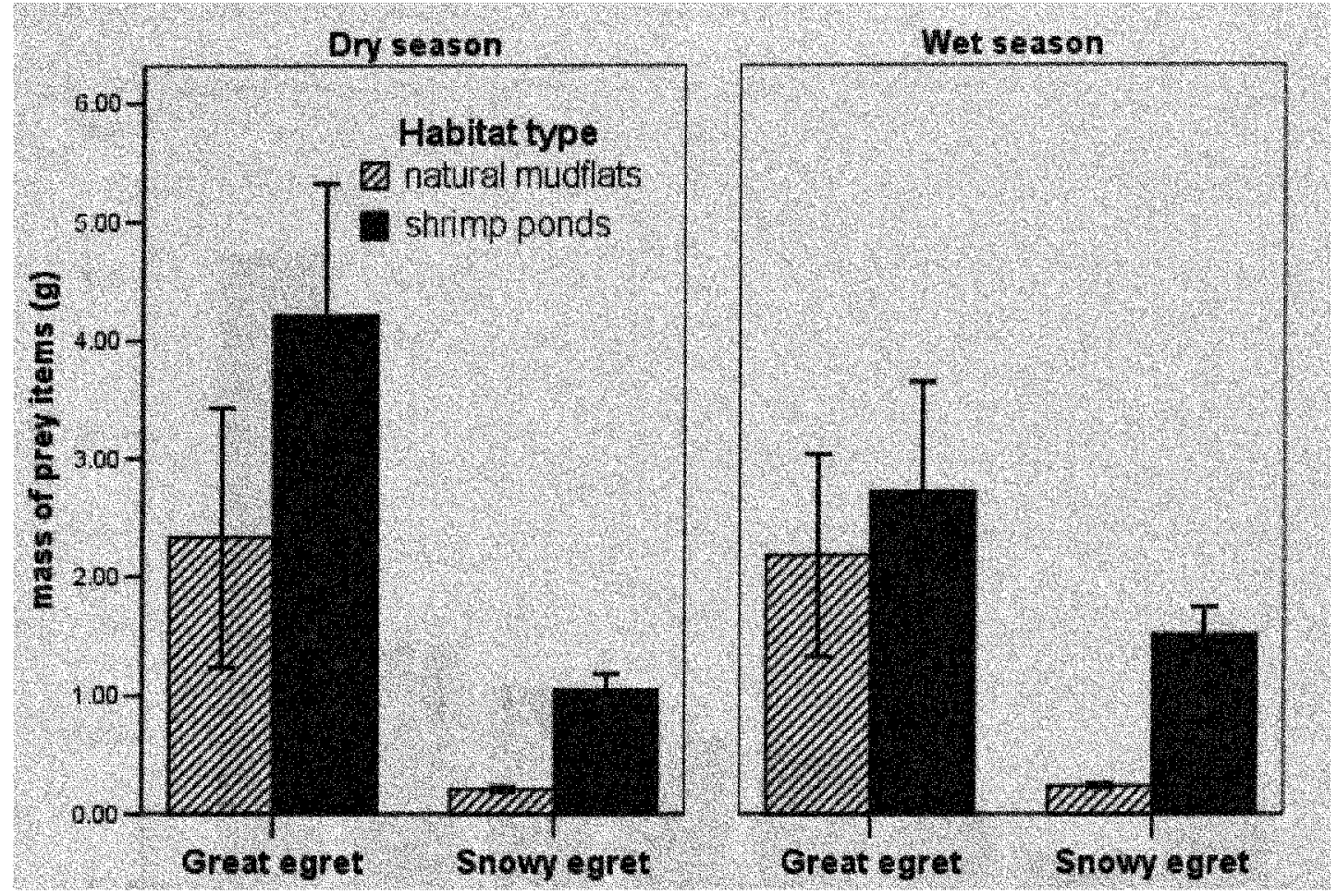

Figure 11. Mean mass of prey items captured by great and snowy egrets in the Muisne River Estuary, Ecuador.

*All prey itens were abserved during focal observation of foraging birds or were found in nestling boluses

Error bars: $+1-1.00 \mathrm{SE}$

species, $16.8 \%$ were G. microdon, $2.2 \%$ were $C$. sagittula, and $0.2 \%$ G. liolepis), $M$. curema (10.8\%), P.vannamei (6.5\%), undetermined Perciformes (1.1\%), P. punctatus $(0.5 \%)$, Gerreidae (0.2\%), snapping shrimp (Family Alpheidae)(0.2\%) (Figure 13 and Table 13).

The most common prey items taken by great egrets in the natural estuary were $M$. curema (34.1\%), Gobiidae (34.1\%, of which $57.2 \%$ were unidentified Gobiidae, $28.7 \%$ were $C$. sagittula, $14.4 \%$ were G. microdon), and $S$. ovale (31.7\%)(Figure 14). The most common prey items in shrimp ponds were P. vannamei $(57.7 \%)$, Gobiidae $(35.6 \%$, of which $51.4 \%$ was $C$. sagittula, $29.8 \%$ were undetermined Gobiidae, and $18.8 \%$ was $G$. 


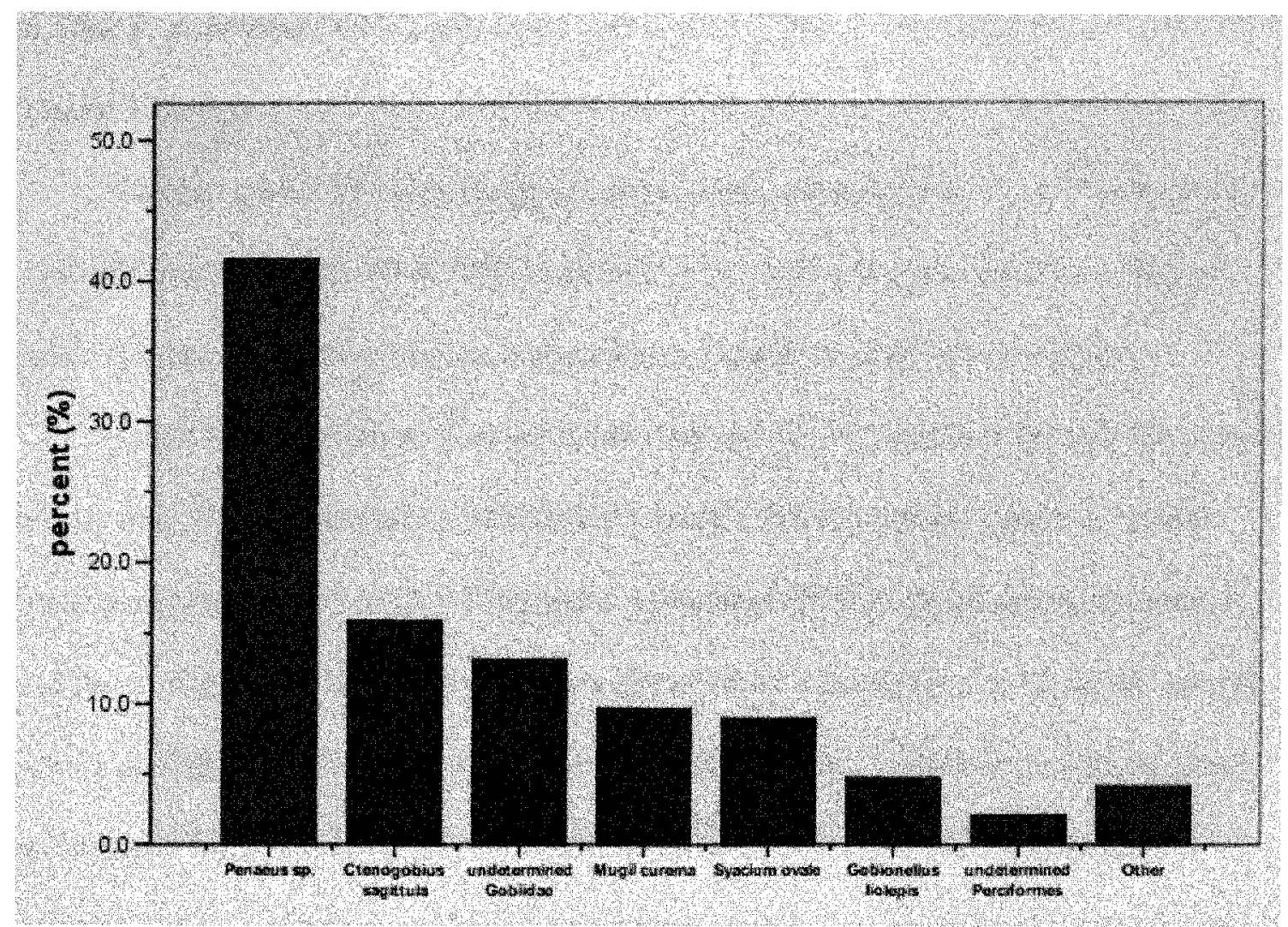

Figure 12. Prey items captured by great egrets in shrimp ponds and natural mudflats in the Musine River Estuary, Ecuador.

liolepis), undetermined Perciformes (2.9\%), and equal numbers of $D$. latifrons and $P$. punctatus ( $1.9 \%$ each)(Figure 15$)$. The most common prey items taken by snowy egrets in the natural estuary were Gobiidae $(86.4 \%$, of which $80.8 \%$ were undetermined Gobiidae, $19.0 \%$ were G. microdon, and $0.2 \%$ C. sagittula), M. curema (13\%), and $P$. vannamei $(0.6 \%)$ (Figure 16$)$. The most common prey items for snowy egrets in shrimp ponds were Gobiidae (54.1\%, of which $81.0 \%$ were unidentified Gobiidae, $17.2 \%$ were C. sagittula, $1.7 \%$ were G. liolepis), P. vannamei (34.5\%), undetermined Perciformes 
$(6.5 \%)$, P. punctatus $(2.8 \%)$, and small numbers of Alpheidae and Gerreidae (0.9\% each). (Figure 17).

Jacobs' electivity index for great egrets suggested a preference for $P$. vannamei $(D=0.569)$ and Gobiidae $(D=0.305)$ in shrimp ponds. All other prey species in shrimp ponds resulted in negative indices, indicating an avoidance of those prey items.

Great egrets preferred $S$. ovale $(\mathrm{D}=0.198)$ and $M$. curema $(\mathrm{D}=0.011)$ in the natural estuary and all other prey species exhibited negative indices. Snowy egrets in shrimp ponds preferred Gobiidae $(\mathrm{D}=0.356)$ and $P$. vannamei $(\mathrm{D}=0.311)$, all other prey species resulted in negative indices. Snowy egrets preferred $M$. curema $(D=0.041)$ in the natural estuary and all other prey species exhibited negative indices. Combining habitats, great egrets preferred $P$, vannamei $(\mathrm{D}=0.293)$ and $S$. ovale $(\mathrm{D}=0.038)$, all other species resulting in negative indices, while snowy egrets preferred $M$. curema $(\mathrm{D}=0.057)$ and all other species were negative.

Nestling Regurgitates

Great egret boluses $(\mathrm{N}=3)$ consisted of 3 adult $P$. vannamei measuring 8, 8.5, and $7 \mathrm{~cm}$ each and weighing $3.5,5$, and $4.5 \mathrm{~g}$, respectively. Biomass in snowy egret boluses $(\mathrm{N}=48)$ were dominated by $P$. punctatus $(63.4 \%, \mathrm{~N}=426)$, C. sagittula $(22.3 \%, \mathrm{~N}=31), P$. vannamei $(9.4 \%, \mathrm{~N}=34), D$. latifrons $(2.6 \%, \mathrm{~N}=1), M$. curema $(1.3 \%, \mathrm{~N}=4)$, unidentified Gobiidae $(0.9 \%, \mathrm{~N}=9)$, and Bathygobius andrei $(0.1 \%, \mathrm{~N}=1)$ (Figure 18). The mean length and mass of all snowy egret prey items was $3.22 \mathrm{~cm}$ and $0.5 \mathrm{~g}$, respectively (Table 14). 
Table 12. Summary table of prey items captured by great egrets in natural mudflats and shrimp ponds in the Muisne River Estuary, Ecuador.

\begin{tabular}{|c|c|c|c|c|c|c|c|}
\hline \multirow[b]{2}{*}{$\begin{array}{l}\text { Prey item } \\
\text { Order }\end{array}$} & \multirow[b]{2}{*}{ Family } & \multirow[b]{2}{*}{ Genus } & \multirow[b]{2}{*}{ Species } & \multicolumn{2}{|c|}{ Natural mudflats } & \multicolumn{2}{|c|}{ Shrimp ponds } \\
\hline & & & & $\begin{array}{l}\text { Total number } \\
\text { of individuals }\end{array}$ & $\begin{array}{l}\% \text { of total } \\
\text { for habitat }\end{array}$ & $\begin{array}{l}\text { Total number } \\
\text { of individuals }\end{array}$ & $\begin{array}{l}\text { \% of total } \\
\text { for habitat }\end{array}$ \\
\hline \multicolumn{2}{|c|}{ *Prey item unidentified } & & & 666 & 94.2 & 868 & 89.3 \\
\hline Decapoda & Penaeidae & Penaeus & $s p$ & - & - & 60 & 6.2 \\
\hline Cyprinodontiformes & Poeciliidae & Profundulus & punctatus & - & - & 2 & 0.2 \\
\hline Mugiliformes & Mugilidae & Mugil & curema & 14 & 2.0 & - & - \\
\hline \multirow[t]{6}{*}{ Perciformes } & Eleotridae & Dormitator & latifrons & - & - & 2 & 0.2 \\
\hline & Gobiidae & Ctenogobius & sagittula & 4 & 0.6 & 19 & 2.0 \\
\hline & & Gobionellus & liolepis & - & - & 7 & 0.7 \\
\hline & & Gobionellus & microdon & 2 & 0.3 & - & - \\
\hline & & und. & und. & 8 & 1.1 & 11 & 1.1 \\
\hline & & und. & larvae & - & - & 3 & 0.3 \\
\hline Pleuronectiformes & Paralicthyidae & Syacium & ovale & 13 & 1.8 & - & - \\
\hline Total & & & 10 & 707 & 100.0 & 972 & 100.0 \\
\hline
\end{tabular}


Table 12, continued. Summary table of prey items captured by great egrets in natural mudflats and shrimp ponds in the Muisne River Estuary, Fcuador.

\begin{tabular}{|c|c|c|c|c|c|c|}
\hline \multirow[b]{2}{*}{$\begin{array}{l}\text { Prey item } \\
\text { Order }\end{array}$} & \multirow[b]{2}{*}{ Family } & \multirow[b]{2}{*}{ Genus } & \multirow[b]{2}{*}{ Species } & \multicolumn{3}{|c|}{ Habitats combined } \\
\hline & & & & $\begin{array}{l}\text { Total number } \\
\text { of individuals }\end{array}$ & $\begin{array}{l}\% \text { of total } \\
\text { for habitat }\end{array}$ & $\begin{array}{c}\% \text { of total } \\
\text { prey identified }\end{array}$ \\
\hline \multicolumn{4}{|l|}{ *Prey item unidentified } & & 1534 & 91.4 \\
\hline Decapoda & Penaeidae & Penaeus & $s p$ & 60 & 3.6 & 41.6 \\
\hline Cyprinodontiformes & Poeciliidae & Profundulus & punctatus & 2 & 0.1 & 1.4 \\
\hline Mugiliformes & Mugilidae & Mugil & curema & 14 & 0.8 & 9.7 \\
\hline \multirow[t]{6}{*}{ Perciformes } & Eleotridae & Dormitator & latifrons & 2 & 0.1 & 1.4 \\
\hline & Gobiidae & Ctenogobius & sagittula & 23 & 1.4 & 15.9 \\
\hline & & Gobionellus & liolepis & 7 & 0.4 & 4.8 \\
\hline & & Gobionellus & microdon & 2 & 0.1 & 1.4 \\
\hline & & und. & und. & 19 & 1.1 & 13.2 \\
\hline & & und. & larvae & 3 & 0.2 & 2.1 \\
\hline Pleuronectiformes & Paralicthyidae & Syacium & ovale & 13 & 0.8 & 9.0 \\
\hline Total & & & 10 & 1679 & 100 & 100.0 \\
\hline
\end{tabular}




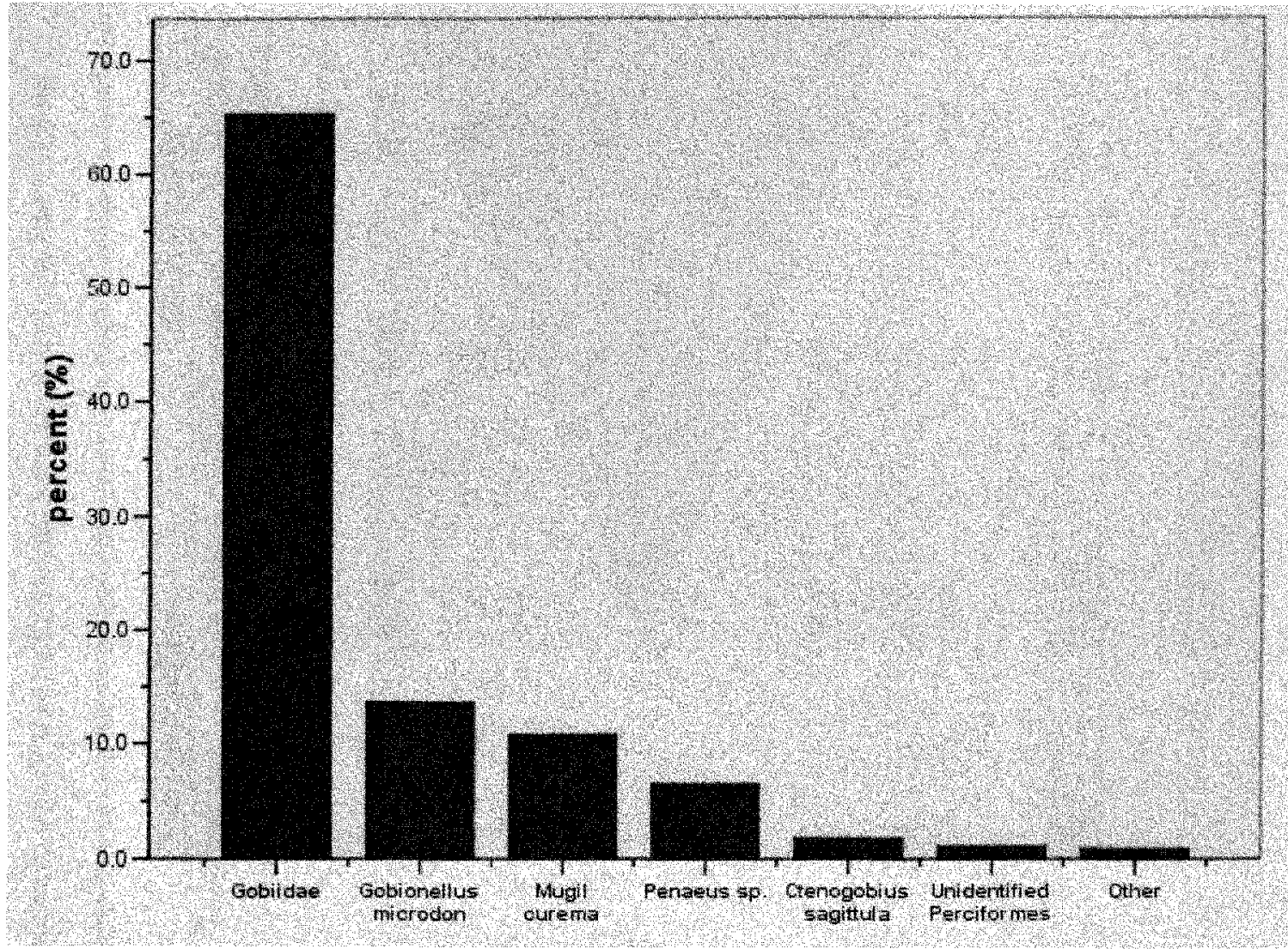

Figure 13. Prey items captured by snowy egrets in shrimp ponds and natural mudflats in the Muisne River Estuary, Ecuador

\section{Prey Populations}

Available Prey

Mean standing crop $\left(\mathrm{g} / \mathrm{m}^{2}\right)$ was significantly greater in shrimp ponds than in the natural estuary and was greatest during the wet season in both habitats $(\mathrm{df}=1, \mathrm{~F}=11.63$, $\mathrm{p}=.001$ )(Figure 19). Although not significantly different, mean density (individuals $/ \mathrm{m}^{2}$ ) of prey items was greater in shrimp ponds than in natural mudflats. However, the opposite is true if water boatman (Corixidae), which were trapped exclusively in shrimp ponds and were never observed being captured by birds, are removed from the analysis. 
Table 13. Summary table of prey items captured by snowy egrets in natural mudflats and shrimp ponds in the Muisne River Estuary, Ecuador.

\begin{tabular}{|c|c|c|c|c|c|c|c|}
\hline \multirow[b]{2}{*}{$\begin{array}{l}\text { Prey item } \\
\text { Order }\end{array}$} & \multirow[b]{2}{*}{ Family } & \multirow[b]{2}{*}{ Genus } & \multirow[b]{2}{*}{ Species } & \multicolumn{2}{|c|}{ Natural mudflats } & \multicolumn{2}{|c|}{ Shrimp ponds } \\
\hline & & & & $\begin{array}{l}\text { Total number } \\
\text { of individuals }\end{array}$ & $\begin{array}{l}\% \text { of total } \\
\text { for habitat }\end{array}$ & $\begin{array}{l}\text { Total number } \\
\text { of individuals }\end{array}$ & $\begin{array}{l}\% \text { of total } \\
\text { for habitat }\end{array}$ \\
\hline \multicolumn{2}{|c|}{ *Prey item unidentified } & & & 347 & 40.7 & 765 & 87.7 \\
\hline \multirow[t]{2}{*}{ Decapoda } & Alpheidae & und. & und. & - & - & 1 & 0.1 \\
\hline & Penaeidae & Penaeus & $s p$. & 3 & 0.4 & 37 & 4.2 \\
\hline Cyprinodontiformes & Poeciliidae & Profundulus & punctatus & - & - & 3 & 0.3 \\
\hline Mugiliformes & Mugilidae & Mugil & curema & 66 & 7.7 & - & - \\
\hline \multirow[t]{6}{*}{ Perciformes } & Gerreidae & und. & und. & - & - & 1 & 0.1 \\
\hline & Gobiidae & Ctenogobius & sagittula & 1 & 0.1 & 10 & 1.1 \\
\hline & & Gobionellus & liolepis & - & - & 1 & 0.1 \\
\hline & & Gobionellus & microdon & 83 & 9.7 & - & - \\
\hline & & und. & und. & 353 & 41.4 & 47 & 5.4 \\
\hline & & und. & larvae & - & - & 7 & 0.8 \\
\hline Total & & & 10 & 853 & 100.0 & 872 & 100.0 \\
\hline
\end{tabular}


Table 13, continued. Summary table of prey items captured by snowy egrets in natural mudflats and shrimp ponds in the Muisne River Estuary, Ecuador.

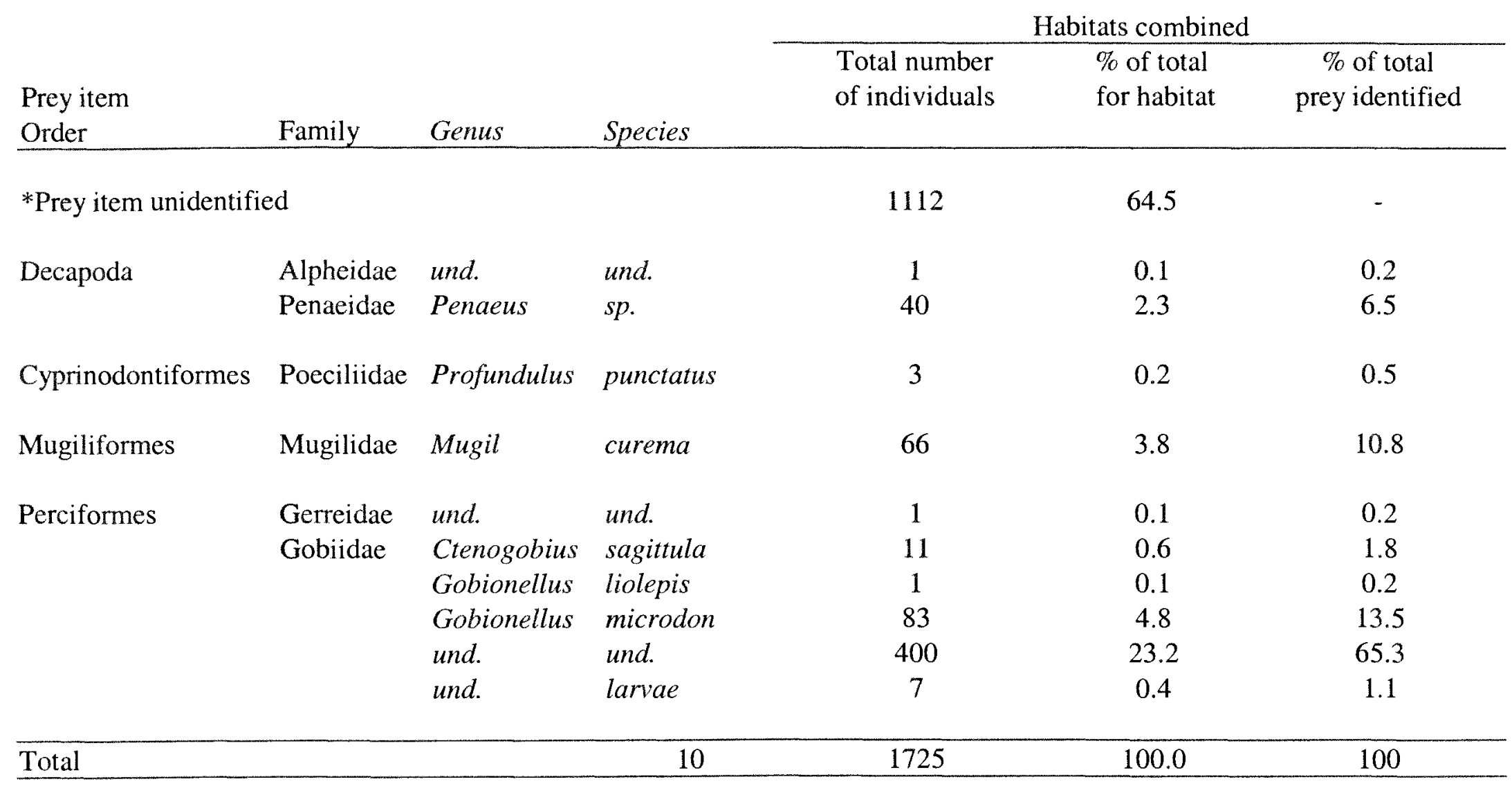




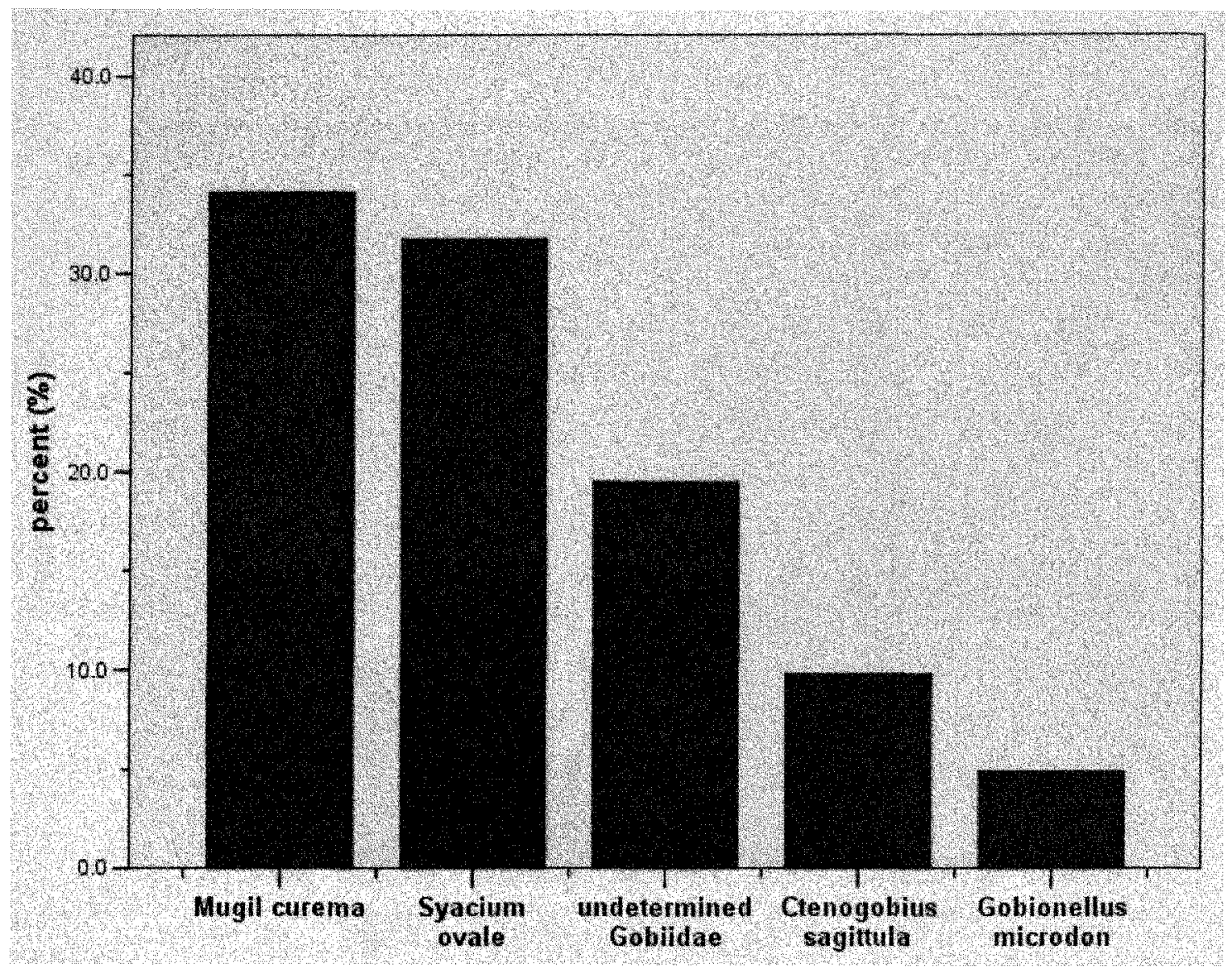

Figure 14. Prey items captured by great egrets in natural mudflats in the Muisne River Estuary, Ecuador

Water boatman were abundant aquatic insects in shrimp ponds that were not observed as wading bird prey during the study and are unlikely to be suitable prey due to their small size.

Mean shrimp pond standing crop was $8.22 \mathrm{~g} / \mathrm{m}^{2}$, averaging 48.5 individuals $/ \mathrm{m}^{2}$ (17.9 individuals $/ \mathrm{m}^{2}$ excluding water boatman). Mean standing crop in the natural estuary was $3.44 \mathrm{~g} / \mathrm{m}^{2}$ averaging 30.4 individuals $/ \mathrm{m}^{2}$. Mean dry season standing crop in both habitats was $4.01 \mathrm{~g} / \mathrm{m}^{2}$ and mean wet season standing crop was $7.1 \mathrm{~g} / \mathrm{m}^{2}$, averaging 58.4 


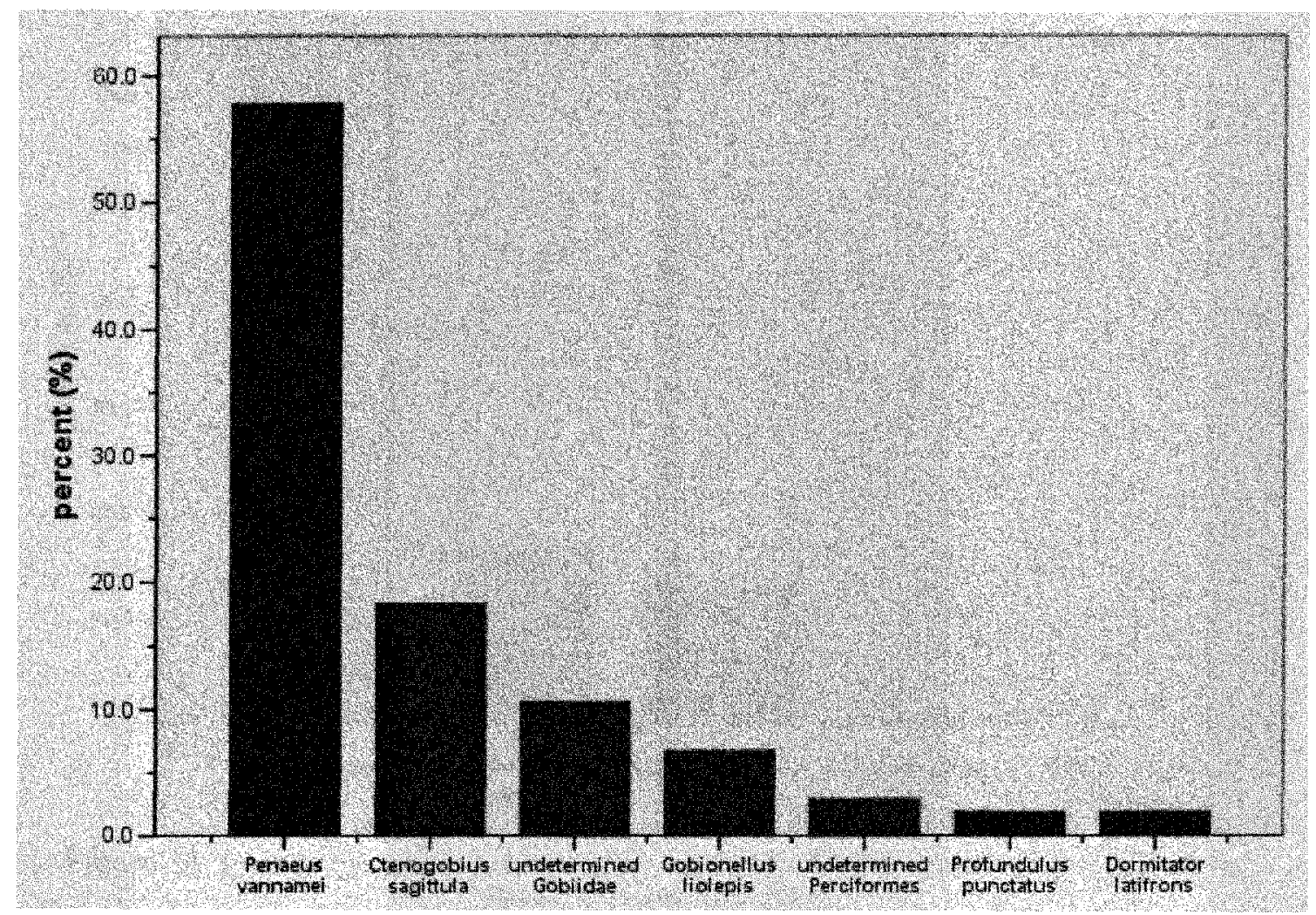

Figure 15. Prey items captured by great egrets in shrimp ponds in the Muisne River Estuary, Ecuador.

individuals $/ \mathrm{m}^{2}$ and 17.3 individuals $/ \mathrm{m}^{2}$, respectively. During the dry season, standing crop averaged $5.86 \mathrm{~g} / \mathrm{m}^{2}$ in shrimp ponds and $2.78 \mathrm{~g} / \mathrm{m}^{2}$ in the natural estuary, averaging 84.4 individuals $/ \mathrm{m}^{2}$ and 41.2 individuals $/ \mathrm{m}^{2}$, respectively. During the wet season standing crop averaged $10.31 \mathrm{~g} / \mathrm{m}^{2}$ in shrimp ponds and $4.23 \mathrm{~g} / \mathrm{m}^{2}$ in the natural estuary, averaging 16.9 individuals $/ \mathrm{m}^{2}$ and 17.6 individuals $/ \mathrm{m}^{2}$, respectively.

The mean mass of individual prey items was significantly greater in shrimp ponds than in the natural estuary and was significantly greater during the wet season in both habitats $(\mathrm{df}=1, \mathrm{~F}=11.63, \mathrm{p}=.001$ and $\mathrm{F}=306.44, \mathrm{p}<.0001$, respectively)(Figure 20). 


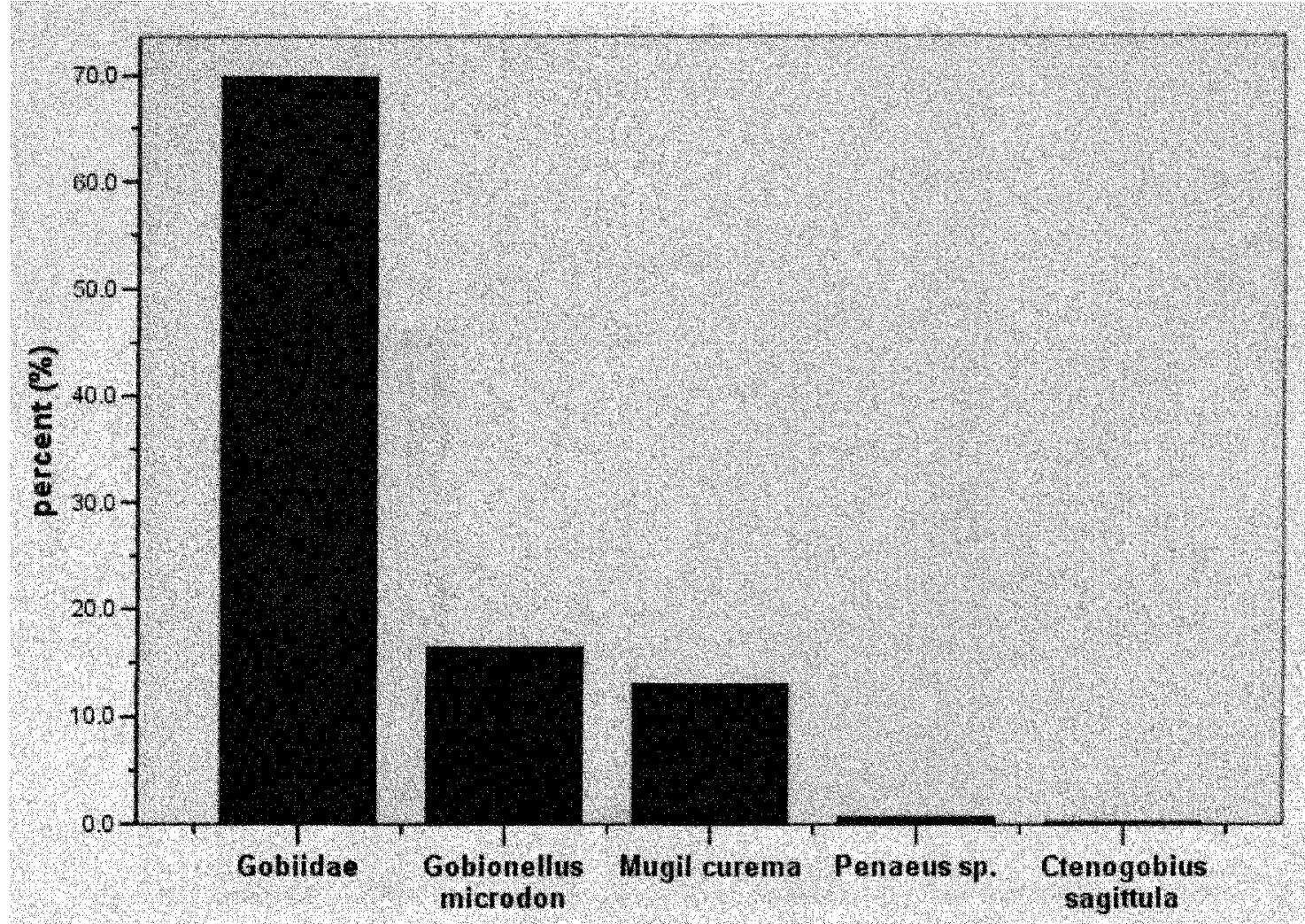

Figure 16. Prey items captured by snowy egrets in natural mudflats in the Muisne River Estuary, Ecuador.

Mean mass of individuals during both seasons combined was $0.170 \mathrm{~g}$ in shrimp ponds and $0.113 \mathrm{~g}$ in the natural estuary, and in both habitats combined was $0.069 \mathrm{~g}$ in the dry season and $0.411 \mathrm{~g}$ in the wet season. During the dry season average mass of individuals was $0.069 \mathrm{~g}$ and $0.067 \mathrm{~g}$ in shrimp ponds and the natural estuary, respectively. During the wet season, average mass of individuals was $0.610 \mathrm{~g}$ and $0.241 \mathrm{~g}$ in shrimp ponds and the natural estuary, respectively. 


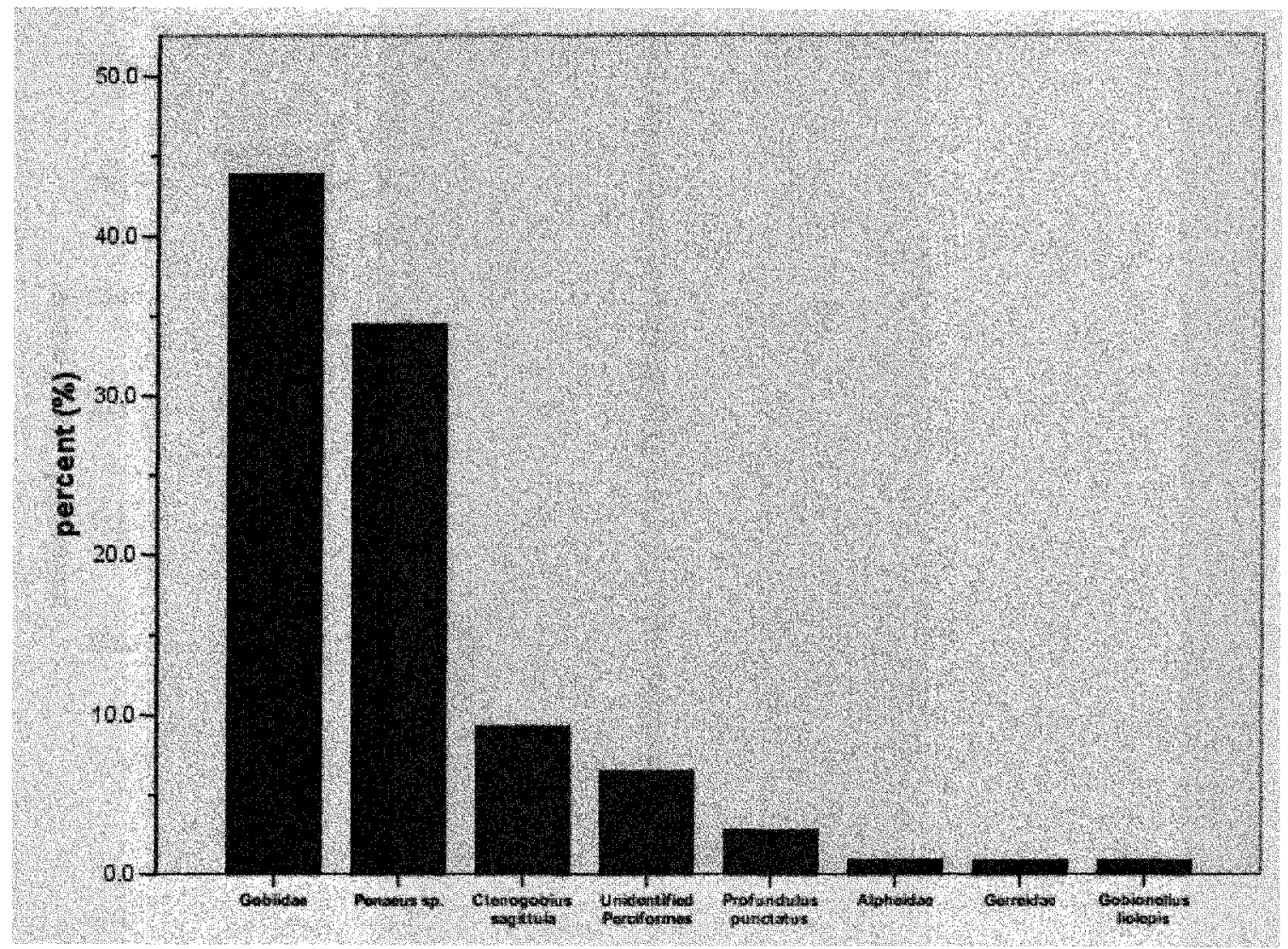

Figure 17. Prey items captured by snowy egrets in shrimp ponds in the Muisne River Estuary, Ecuador.

Microhabitats Sampled

Water depths at foraging sites were significantly deeper in shrimp ponds than in the natural estuary $(\mathrm{df}=1, \mathrm{~F}=2576, \mathrm{p}<0.0001)$ (Figure 21$)$. Mean throw trap depth in shrimp ponds was $14.97 \mathrm{~cm}$ while in the natural estuary depths averaged $8.51 \mathrm{~cm}$. Water depths were greater during the wet season $(15.22 \mathrm{~cm})$ than during the dry season $(11.16 \mathrm{~cm})$ across both habitats $(\mathrm{df}=1, \mathrm{~F}=620.45, \mathrm{p}<0.0001)$. Biomass increased significantly with water depth $(\mathrm{df}=1, \mathrm{~F}=31.2, \mathrm{p}<0.0001)$, although exhibiting only a very weak linear relationship $\left(\mathrm{r}^{2}=.087\right)$. 


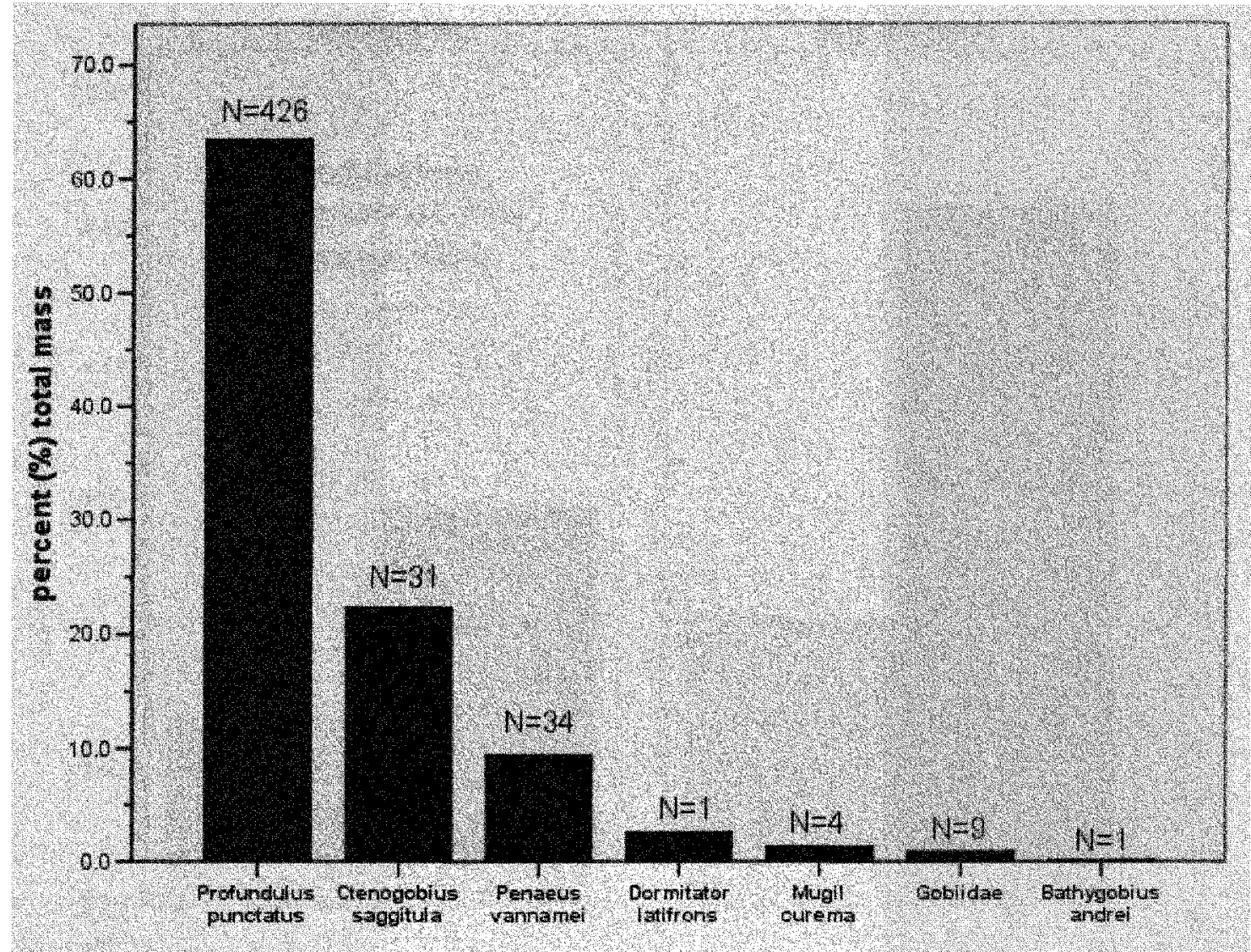

Figure 18. Percent biomass of prey items $(N=503)$ found in snowy egret boluses $(\mathrm{N}=48)$ in the Muisne River Estuary, Ecuador.

Table 14. Summary of snowy egret nestling boluses $(\mathrm{N}=48)$ at the Las Manchas Colony, Muisne River Estuary, Ecuador

\begin{tabular}{|c|c|c|c|c|c|c|}
\hline $\begin{array}{l}\text { Prey Item } \\
\text { Family }\end{array}$ & Genus and species & $\begin{array}{l}\text { Number of } \\
\text { individuals }\end{array}$ & $\begin{array}{c}\text { \% of } \\
\text { individuals }\end{array}$ & $\begin{array}{c}\% \text { of } \\
\text { total mass }\end{array}$ & $\begin{array}{l}\text { Mean total } \\
\text { length }(\mathrm{cm})\end{array}$ & $\begin{array}{c}\text { Mean } \\
\operatorname{mass}(\mathrm{g})\end{array}$ \\
\hline Poeciliidae & Profundulus punctatus & 426 & 84.7 & 63.4 & 2.86 & 0.36 \\
\hline Penaeidae & Penaeus vannamei & 31 & 6.2 & 22.3 & 4.39 & 0.72 \\
\hline Gobiidae & Ctenogobius sagittula & 31 & 6.2 & 9.4 & 6.27 & 1.73 \\
\hline Gobiidae & undetermined species & 9 & 1.8 & 2.6 & 2.78 & 0.24 \\
\hline Mugilidae & Mugil curema & 4 & 0.8 & 1.3 & 4.8 & 0.8 \\
\hline Eleotridae & Dormitator latifrons & 1 & 0.2 & 0.9 & 8.5 & 6.2 \\
\hline Gobiidae & Bathygobius andrei & 1 & 0.2 & 0.1 & 3.2 & 0.2 \\
\hline Total & $\mathrm{N}=6$ & 503 & 100.0 & 100.0 & 3.22 & 0.5 \\
\hline
\end{tabular}




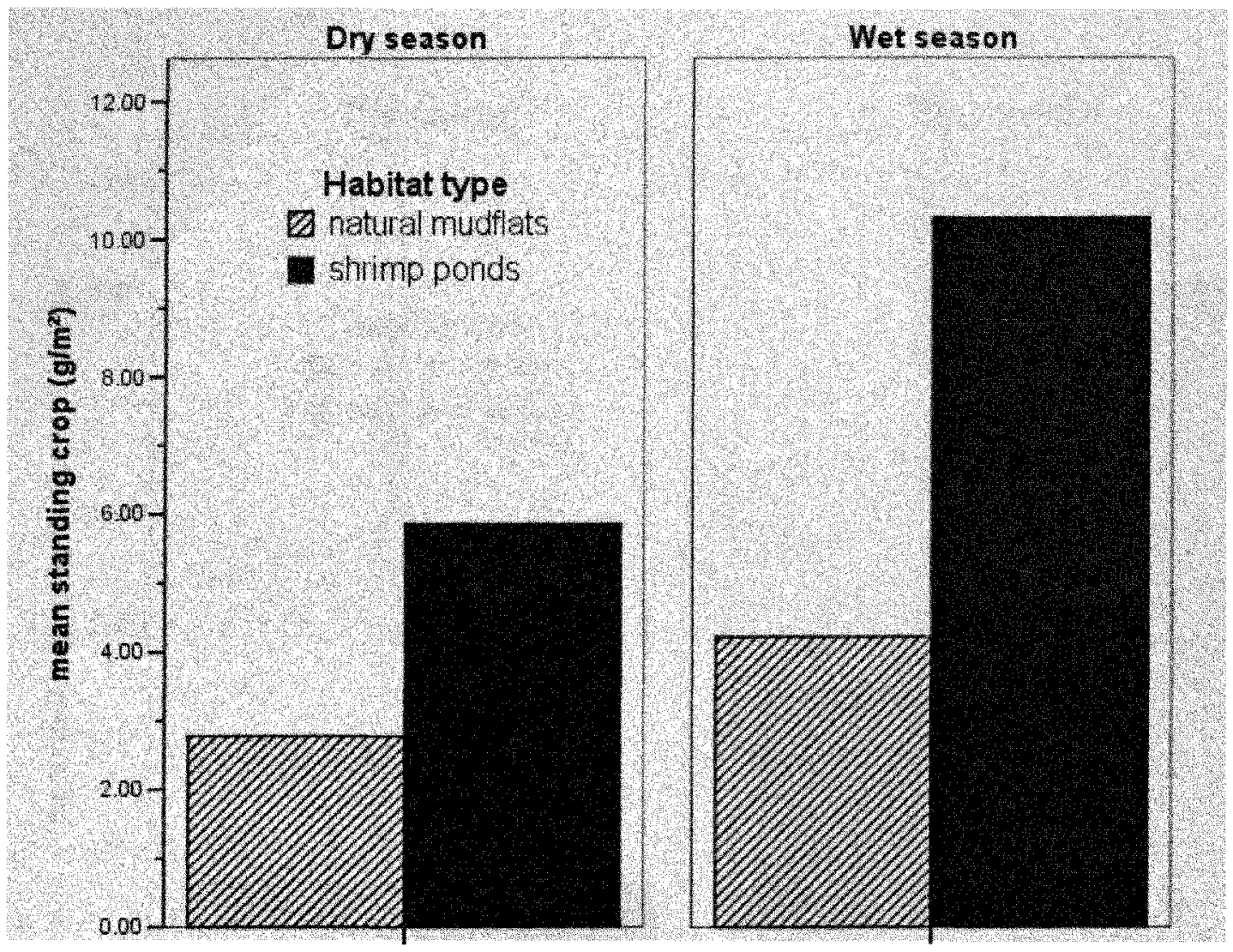

Figure 19. Mean standing crop $\left(\mathrm{g} / \mathrm{m}^{2}\right)$ of prey items in natural mudflats and shrimp ponds in the Muisne River Estuary, Ecuador.

Mean salinity in shrimp ponds (30.8 ppt) was significantly greater than in the natural estuary $(28.9 \mathrm{ppt})(\mathrm{df}=1, \mathrm{~F}=491.48, \mathrm{p}<0.0001)$ and was significantly greater during the dry season $(30.9 \mathrm{ppt})$ than during the wet season $(26.6 \mathrm{ppt})$ in both habitats combined $(\mathrm{df}=1, \mathrm{~F}=1844.01, \mathrm{p}<.0001)$. Seasonal means within shrimp ponds $(29.3 \mathrm{ppt}(\mathrm{wet})$ and $31.1 \mathrm{ppt}$ (dry)) were greater than within the natural estuary (24.5 ppt (wet) and $30.5 \mathrm{ppt}$ (dry)). 


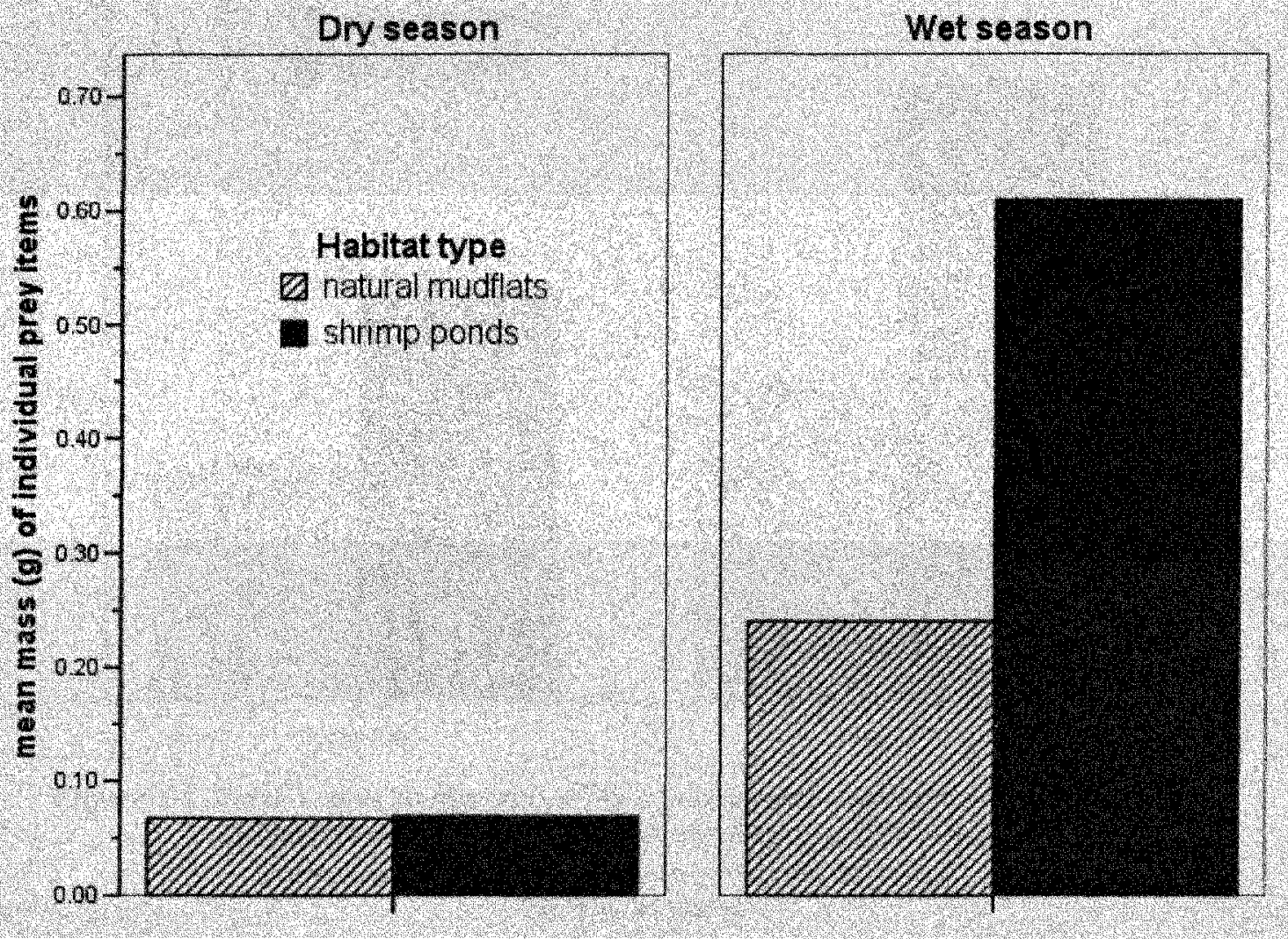

Figure 20. Mean mass of individual prey items captured in throw traps in natural mudflats and shrimp ponds in the Muisne River Estuary, Ecuador.

Species Diversity

Diversity (Shannon's index) of estuarine prey items differed significantly between habitats $(\mathrm{df}=173, \mathrm{t}=2.63, \mathrm{p}<0.05)$ and by season $(\mathrm{df}=173, \mathrm{t}=7.90, \mathrm{p}<0.05)$. Shrimp ponds had a Shannon's $H=0.898$ and a Buza's eveness measure of $E=0.1292$. The natural estuary had a Shannon's $H=1.235$ and a Buza's eveness measure of $E=0.181$. During the dry season in all habitats there were 21 species observed, a Shannon's $\mathrm{H}=1.421$ and a Buza's eveness measure of $E=0.1972$. During the wet season in all habitats there were 23 species observed, a Shannon's H=2.165 and a Buza's eveness measure of $E=0.379$. 


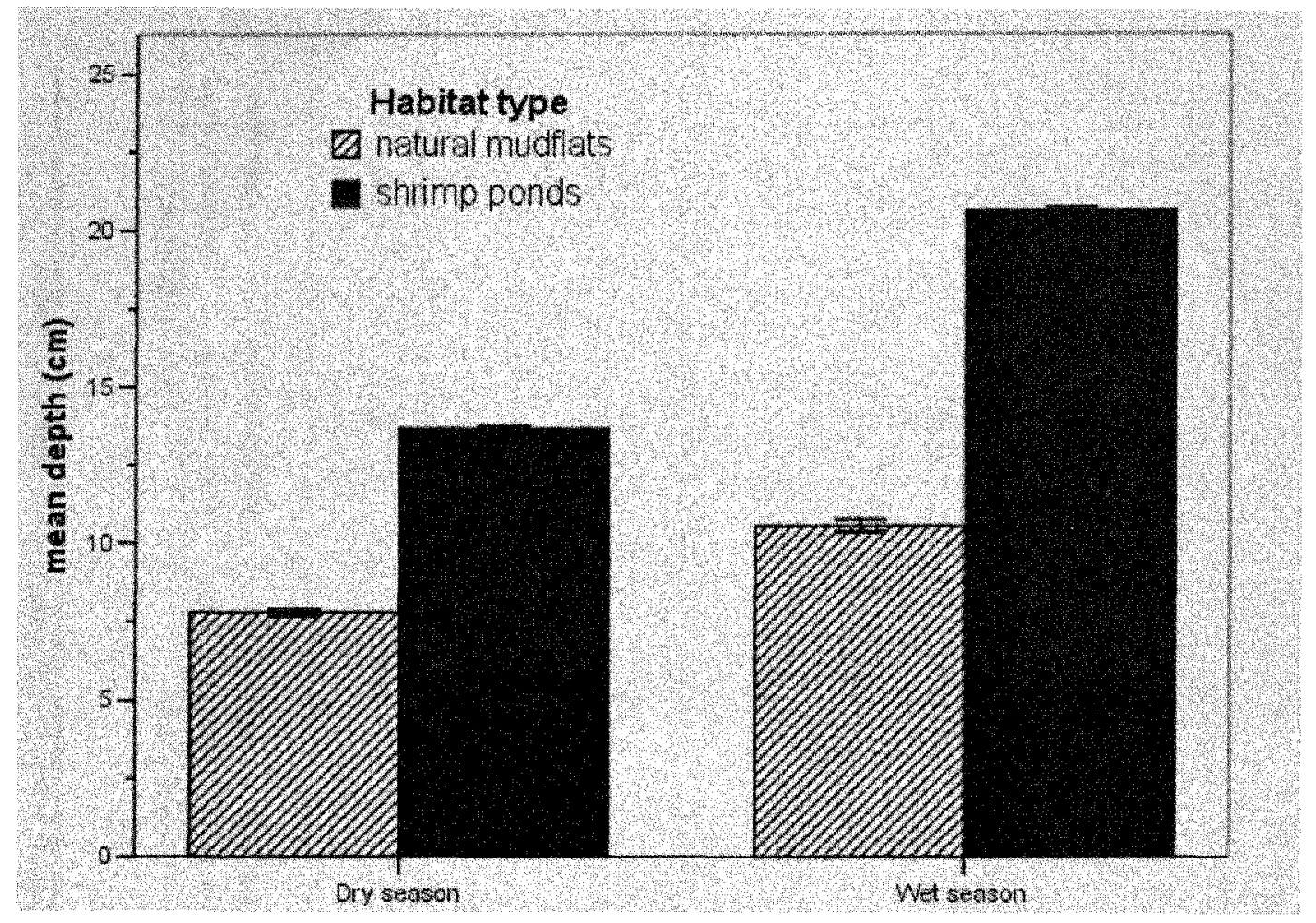

Figure 21. Mean water depth $(\mathrm{cm})$ of foraging areas in natural mudflats and shrimp ponds in the Muisne River Estuary, Ecuador.

Water depths were measured during throw trap sampling Error bars: + /- $1.00 \mathrm{SE}$

Although 19 species of potential prey items were present in each habitat, they shared only 11 species (Table 15). Species sampled exclusively in shrimp ponds were Centropomus sp., D. latifrons, G. liolepis, Haemulon sexfasciatum, Microgobius crocatus, $M$. curtus, M. embelematicus, and P. punctatus. Species trapped exclusively in the natural estuary were Callinectes sp., Daector dowi, Eleotris picta, M. curema, larval P. vannamei, Sphoeroides annulatis, $P$. stylirostris, and Syacium ovale. 
Table 15. Summary table of prey items captured in throw traps in natural mudflats and shrimp ponds in the Muisne River Estuary, Ecuador.

\begin{tabular}{|c|c|c|c|c|c|c|c|c|}
\hline \multirow[b]{2}{*}{ Prey item } & \multirow[b]{2}{*}{ Genus } & \multirow[b]{2}{*}{ Species } & \multicolumn{2}{|c|}{ Natural mudflats } & \multicolumn{2}{|c|}{ Shrimp ponds } & \multicolumn{2}{|c|}{ Habitats combined } \\
\hline & & & $\begin{array}{l}\text { Total number } \\
\text { of individuals }\end{array}$ & $\begin{array}{c}\% \text { of total w/in } \\
\text { habitat type }\end{array}$ & $\begin{array}{l}\text { Total number } \\
\text { of individuals }\end{array}$ & $\begin{array}{c}\% \text { of total w/in } \\
\text { habitat type }\end{array}$ & $\begin{array}{l}\text { Total number } \\
\text { of individuals }\end{array}$ & $\begin{array}{c}\% \text { of total w/in } \\
\text { habitat type }\end{array}$ \\
\hline \multicolumn{3}{|c|}{ *Empty throw trap sample } & 63 & 1.1 & 35 & 0.5 & 98 & 0.8 \\
\hline Corixidae & & & 37 & 0.6 & 4365 & 62.6 & 4402 & 34.7 \\
\hline Portunidae & Callinectes & $s p$ & 59 & 1.0 & 0 & 0.0 & 59 & 0.5 \\
\hline Xanthidae & Menipes & frontalis & 7 & 0.1 & 59 & 0.8 & 66 & 0.5 \\
\hline Alpheidae & undetermined & undetermined & 23 & 0.4 & 2 & 0.0 & 25 & 0.2 \\
\hline Penaeidae & Penaeus & $s p$ & 180 & 3.2 & 67 & 1.0 & 247 & 1.9 \\
\hline Atherinidae & Atherinella & pachylepis & 92 & 1.6 & 1 & 0.0 & 93 & 0.7 \\
\hline Batrachoididae & Daector & dowi & 7 & 0.1 & 0 & 0.0 & 7 & 0.1 \\
\hline Poeciliidae & Profundulus & punctatus & 0 & 0.0 & 2252 & 32.3 & 2252 & 17.8 \\
\hline Mugilidae & Mugil & curema & 70 & 1.2 & 0 & 0.0 & 70 & 0.6 \\
\hline \multicolumn{2}{|c|}{ Centropomidae Centropomus } & $s p$ & 0 & 0.0 & 2 & 0.0 & 2 & 0.0 \\
\hline \multirow[t]{2}{*}{ Eleotridae } & Dormitator & latifrons & 0 & 0.0 & 63 & 0.9 & 63 & 0.5 \\
\hline & Eleotris & picta & 2 & 0.0 & 0 & 0.0 & 2 & 0.0 \\
\hline Gerreidae & undetermined & undetermined & 436 & 7.6 & 20 & 0.3 & 456 & 3.6 \\
\hline
\end{tabular}


Table 15, continued. Summary table of prey items captured in throw traps in natural mudflats and shrimp ponds in the Muisne River Estuary, Ecuador.

Natural mudflats

Shrimp ponds

Habitats combined

Total number $\%$ of total w/in Total number \% of total w/in Total number \% of total w/in

Prey item

Total number habitat type

of individuals

habitat type

\begin{tabular}{|c|c|c|c|c|c|c|c|c|}
\hline Family & Genus & Species & & & & & & \\
\hline \multirow{8}{*}{ Gobiidae } & Bathygobius & andrei & 8 & 0.1 & 20 & 0.3 & 28 & 0.2 \\
\hline & Ctenogobius & sagittula & 568 & 9.9 & 17 & 0.2 & 585 & 4.6 \\
\hline & Gobionellus & liolepis & 0 & 0.0 & 3 & 0.0 & 3 & 0.0 \\
\hline & Gobionellus & microdon & 3934 & 68.8 & 27 & 0.4 & 3961 & 31.2 \\
\hline & Microgobius & crocatus & 0 & 0.0 & 4 & 0.1 & 4 & 0.0 \\
\hline & Microgobius & curtus & 0 & 0.0 & 1 & 0.0 & 1 & 0.0 \\
\hline & Microgobius & emblematicus & 0 & 0.0 & 5 & 0.1 & 5 & 0.0 \\
\hline & undetermined & undetermined & 86 & 1.5 & 15 & 0.2 & 101 & 0.8 \\
\hline Haemulidae & Haemulon & sexfasciatum & $\mathbf{0}$ & 0.0 & 2 & 0.0 & 2 & 0.0 \\
\hline undetermined & undetermined & undetermined & 70 & 1.2 & 8 & 0.1 & 78 & 0.6 \\
\hline Paralicthyidae & Syacium & ovalum & 68 & 1.2 & 0 & 0.0 & 68 & 0.5 \\
\hline Tetraodontidae & Sphoeroides & annulatis & 4 & 0.1 & 0 & 0.0 & 4 & 0.0 \\
\hline Total & & 25 species & 5714 & 100.0 & 6968 & 100.0 & 12682 & 100 \\
\hline
\end{tabular}




\section{DISCUSSION}

Flight line Counts

Most birds from the Las Manchas colony flew to and from habitat dominated by shrimp farms during their daily foraging flights, suggesting this area provided critical feeding habitat during the breeding season. However, tracking individual birds from the colony until their arrival at foraging areas was beyond the scope of this study, but is of future research interest. The colony was dominated by great, snowy and cattle egrets (together comprising $>70 \%$ of roosting birds), species that preferentially foraged in shrimp ponds, or agricultural fields in the case of the cattle egret. Due to lack of historical data however, it is uncertain whether these birds numerically dominate the colony as a result of the increase in shrimp pond and agricultural areas, or whether they were the most abundant species at the colony prior to natural habitat loss. The case is similar in Mediterranean Europe, where it is unclear whether birds that depend heavily upon rice fields are preferentially selecting rice fields, or whether they are simply utilizing the most abundant landscape available in areas where only $10-20 \%$ of former natural habitat remains (Fasola and Ruiz 1996; Fasola et al. 1996).

It is likely that the increased acreage of uplands resulting from shrimp farm construction (e.g. vegetated berms, roads, staging areas, house pads, etc.) has facilitated the reproduction of cattle egrets in the area, a species unlikely to have been present in large numbers in closed-canopy forested uplands and mangroves of the early $20^{\text {th }}$ century. The arrival of cattle egrets may have adversely affected reproduction of other ardeids by increasing competition for nest sites and nesting materials during the breeding season (Telfair 1994). 
Censuses

Greater densities of wading birds during the dry (non-breeding) season could be explained by several factors. The most likely explanation is the immigration of birds from more seasonal estuaries to the south where the dry season is much more pronounced, possibly affecting prey availability late in the season. Another possibility is the influx of northern migrants during the boreal winter. Records of both snowy egrets and little blue herons tagged in North America have been documented in Ecuador (Klimkiewicz, per. com. 2004).

Natural mudflats contained higher mean densities of birds due to the greater presence of the less abundant species (i.e. striated heron, little blue heron, tricolored heron, and yellow-crowned night heron) in addition to the ubiquitous great and snowy egrets. The less numerous species were found in significantly smaller numbers in shrimp ponds, which were dominated by great and snowy egrets. Additionally, prey availability for these medium-sized species was greater in the natural estuary than in shrimp ponds due to shallower water depths and greater prey species diversity. These species were present in greater numbers in shrimp ponds only during harvest ('boom') events, which typically occurred simultaneously at many farms throughout the estuary during the bimonthly spring tides ('aguaje'). During brief 2-4 day harvest events, large-sized prey items $(>8-10 \mathrm{~cm})$ become concentrated in drainage moats, allowing birds to become satiated quickly. Within 5 days or less however, prey availability is significantly decreased via predation, dessication, and/or by the reflooding of ponds with filtered estuarine water, effectively excluding prey larger than $1 \mathrm{~mm}$. Wading bird densities 
reflected this 'boom-bust' cycle within shrimp ponds by exhibiting both the maximum and minimum number of birds observed during a single survey date.

Wading bird diversity was slightly greater in the natural estuary due to the greater evenness of species distributions. B. striatus, E. caerulea, E. tricolor, and $N$. violacea were underrepresented in shrimp ponds and more abundant on mudflats, where they were present in more balanced proportions relative to great and snowy egrets. In contrast, bird diversity in shrimp ponds was lower and less even due to a strong dominance in numbers of individuals by great and snowy egrets. Great egrets have responded similarly to anthropogenic disturbance in the Florida Everglades, where they were more abundant in nutrient enriched freshwater wetlands relative to naturally oligotrophic wetlands (Crozier and Gawlik 2002).

Greater wading bird diversity in natural mudflats can be attributed to the greater diversity of prey items, microhabitat types, and water depths (see Prey Availability below). Similar results have been observed in the Venezuelan llanos where non-diked freshwater wetlands harbored greater species diversity than diked areas due to differences in water depths, microhabitat structure, and soil fauna (Morales and Pacheco 1986). The black-crowned night heron was not observed foraging in the natural estuary and was rare in shrimp ponds during the daytime. This crustacean specialist is largely nocturnal at the study site and its use of shrimp ponds warrants further study.

Foraging Behavior

Strike and capture rates were greatest in the natural estuary due to the higher density and smaller size of prey items. Both great and snowy egrets captured larger 
numbers of smaller-sized prey items in the natural estuary by foraging across open mudflats during low tide. During this time the mudflats contained numerous drying pools of water with high densities (up to 1,003 individuals $/ \mathrm{m}^{2}$ ) of small $(<4 \mathrm{~cm} \mathrm{TL}$ ) fish (Gobiidae) and Penaeid shrimp. Thus the birds required greater numbers of prey items to meet daily energy requirements in this habitat, hence the higher strike and capture rates. In contrast, strike and capture rates were lower in shrimp ponds where birds were capturing fewer, but larger prey items, thus obtaining more energy per unit effort.

In contrast to the results of a study of seasonal great and snowy egret capture efficiencies in New Jersey and Florida, great egrets at the study site did feed significantly more efficiently during the breeding season and snowy egrets did not (Erwin 1985). One possible explanation is that prey was readily abundant during the wet season and was not a limiting factor in reproductive output for snowy egrets. This idea is supported by the relatively low capture efficiency and high capture rate (captures/minute) of snowy egrets here relative to other sites in North America (Horn 1983; Rogers 1983; Kent 1986, 1987; Maccarone and Parsons 1994; Maccarone and Brzorad 2002). Prey capture rates were relatively lower for great egrets in relation to the abovementioned studies and availability of larger, high energy content prey items may have been more of a limiting factor during breeding for this larger species.

Strike and capture rates were significantly higher in snowy egrets than in great egrets due to their more active feeding behavior of walking slowly/quickly versus the stand and wait predation of most great egrets. As demonstrated elsewhere in the United States (Willard 1977; Horn 1983) and Mexico (Ramo and Busto 1993), great egrets here caught larger prey items and foraged in deeper water than snowy egrets. This outcome is 
predicted by optimal foraging theory and morphological characteristics of both species.

The larger body and bill size of great egrets allows for the capture and manipulation of larger prey items to meet energetic demands, and longer legs allow for greater maximum foraging depths to reach larger prey (Kushlan 1978). In contrast, smaller snowy egrets are able to meet their relatively lower energetic demand with smaller sized prey items captured in shallower depths with a shorter bill and legs.

Great egrets may have fed in deeper water within the estuary because schools of fish of suitable size were found there at greater depths than in the shrimp ponds. Great egrets were able to stalk schools of fast-moving fish in the estuary at greater depths than in shrimp ponds because of the gentler slope of the mudflat shoreline. However, feeding at greater depths reduces visibility and increases escape time for prey items, partly explaining the reduced capture efficiency of great egrets within the estuary. In contrast, similar high quality prey items were found at shallower depths in shrimp farms. The opposite was true of the snowy egret, little blue heron, tricolored heron, and yellowcrowned night heron, which all foraged at significantly greater depths in shrimp ponds than in the natural estuary, where preferred prey items were encountered in shallower water.

Great egrets were best able to utilize both the shorelines and open water of shrimp ponds due to a greater maximum foraging depth $(\approx 40 \mathrm{~cm})$ and ability to capture larger prey items $(>10 \mathrm{~cm})$. Snowy egrets also regularly utilized both shorelines and open water in shrimp ponds, although their foraging efficiency there was not significantly greater than in the estuary as for great egrets. In shrimp ponds, snowy egrets were restricted to shallower areas along the shorelines or in the interior near emergent mangrove stumps or 
other aquatic vegetation. Snowy egrets were presumably limited to fewer ponds whose open water and shoreline areas did not exceed their maximum foraging depth $(\approx 17 \mathrm{~cm})$.

Their wide array of foraging methods and affinity for crustacean prey may have enhanced their ability to forage regularly in shrimp ponds despite their smaller size (Parsons and Master 2000; Miranda and Collazo 1997).

Great egrets and snowy egrets fed more actively in the natural estuary than in shrimp farms due to a greater unevenness in prey item distribution (i.e. greater standard deviation of prey density in the natural estuary). Food resources for prey items, and thus prey items themselves, were likely irregularly distributed within the tidally-influenced estuary, where currents can reach over 5 knots/hour and water levels can rise greater than $1 \mathrm{~cm} /$ minute, submerging tens of hectares of exposed mudflat in less than 30 minutes. In contrast, prey items were more evenly distributed (i.e. lower standard deviation of density from throw traps) within diked ponds due to controlled water elevations, lack of turbulance from tidal currents, more even distribution of primary food resources due to systematic supplemental feeding and the resultant increases in primary productivity within these closed systems.

The dominance of snowy egret boluses by $P$. punctatus, a species not captured by throw trapping within the natural estuary, indicated that most chicks were being fed prey items captured exclusively in shrimp ponds. Due to logistical constraints, nestling boluses were only collected during an 8 day period after the initiation of hatching within the colony, and a shift in principal food items may have occurred as the season progressed.

Preferred prey items of both great and snowy egrets were generally similar to those reported from other tropical estuaries, where both species consumed primarily fish 
and crustaceans (Ramo and Busto 1993; Miranda and Collazo 1997). However, proportions and species differ considerably from those taken in Mexico and Puerto Rico, where great egret diet was dominated by fish ( $>93 \%$ each) in both studies and snowy egret diet was dominated by fish (95\%) in Mexico and shrimp (78.4\%) in Puerto Rico. Based on focal observations of foraging birds, great egret diet in Ecuador was dominated by Penaeid shrimp (41.6\%) and Gobiid fish (35.3\%), while snowy egret diet was dominated by Gobiid fish (80.8\%), M. curema (10.8\%), and Penaeid shrimp (6.5\%). Jacobs' electivity indices for great egrets suggested a preference for $P$, vannamei and $S$. ovale over all other available prey items, while snowy egrets preferred $M$. curema over other species. All other prey species resulted in negative indices, indicating an avoidance of those prey items. Analysis of caloric content of prey species is of future research interest to address the question of whether birds are selecting given prey items based on energetic value or other factors.

\section{Microhabitats}

All species foraged primarily on exposed mudflats and along the shorelines of both shrimp ponds and natural mudflats, with most individuals foraging $>20 \mathrm{~m}$ from aquatic vegetation. This is due to the general lack of emergent aquatic vegetation within both habitats aside from mangrove trees, which did not offer suitable wading bird foraging areas. 


\section{Prey Availability}

Prey availability (a function of species composition, density, standing crop, and water depth) within shrimp ponds was limited due to species composition and water depth. Although density and standing crop of prey items was greater in shrimp ponds than on mudflats, diversity was lower and availability was restricted due to the slope (generally $>40 \%$ ) along the shoreline and depth $(>50 \mathrm{~cm})$ throughout the ponds. In contrast, natural foraging grounds contained a greater diversity and density of suitable prey items on mudflats with moderately sloped banks (generally $<15 \%$ ) and shallow water $(<50 \mathrm{~cm})$ over larger contiguous areas.

Mean standing crop within the natural estuary was similar to maximum values in Florida dwarf mangrove areas $\left(\approx 4 \mathrm{~g} / \mathrm{m}^{2}\right)$ (Green et al. 2006; Lorenz 1999) and less than estimated standing crop in the Venezuelan llanos $\left(6-7 \mathrm{~g} / \mathrm{m}^{2}\right)$ (Kushlan et al. 1985) and freshwater marshes in one Florida Everglades study $\left(5 \mathrm{~g} / \mathrm{m}^{2}\right)$ (Lorenz 1999), although values in the llanos were not estimated using throw traps. Mean standing crop in shrimp ponds was greater than in these same areas. Prey densities in the natural estuary were greater than in northeastern Florida Bay $\left(6.5 \mathrm{fish} / \mathrm{m}^{2}\right)$ (Ley et al. 1999), southeastern Everglades (Lorenz and Serafy 2006; Faunce et al. 2004; Lorenz 1999), and less than densities in mangroves of Puerto Rico (Miranda and Collazo 1997). To my knowledge, standing crop measurements from other tropical estuaries using similar methodologies have not been conducted to date (Miranda and Collazo 1997).

The typical design of ponds includes a shallow basin surrounded at the perimeter by a deep drain channel ('moat') and an earthen berm. The earthen berm is typically 
created with spoil taken from within the pond basin, thereby creating the deep $(>1 \mathrm{~m})$, linear moat used for controlling water levels and harvesting shrimp (Figure 22).

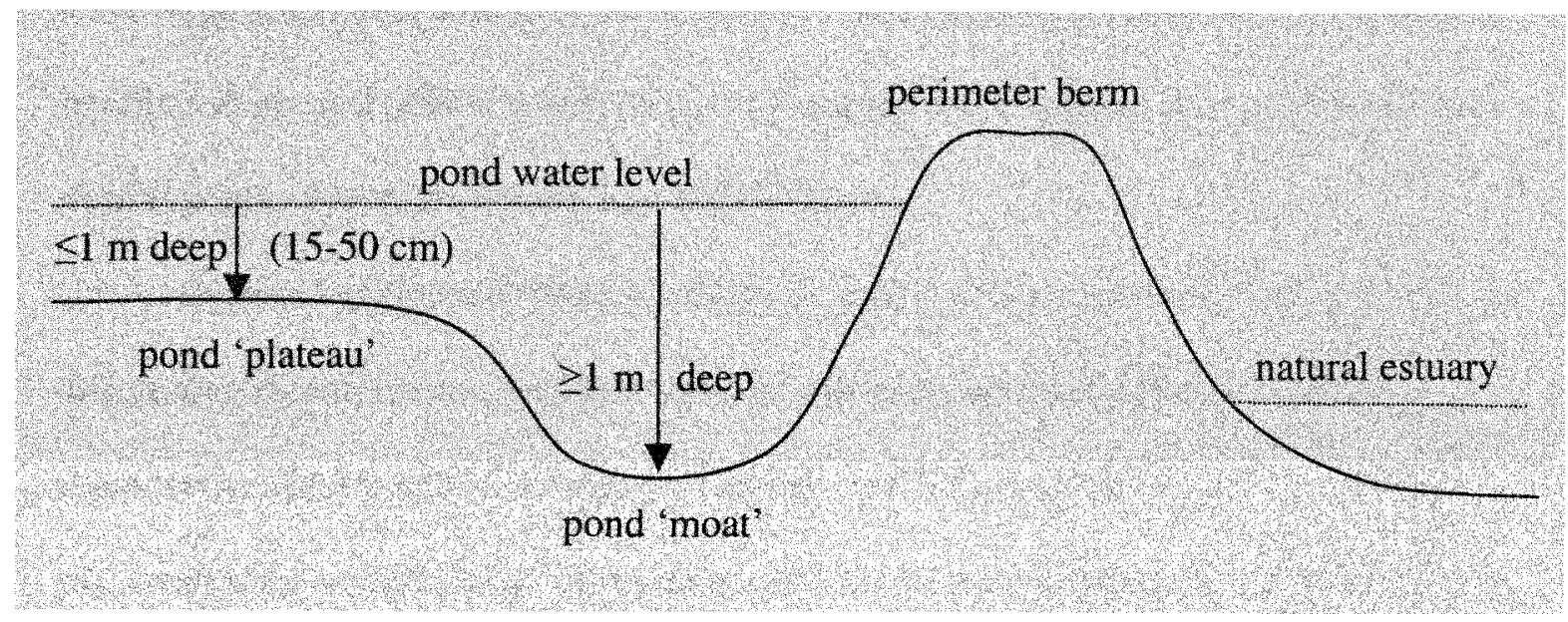

Figure 22. Typical shrimp pond contour profile at study site in Muisne River Estuary, Esmeraldas, Ecuador.

This moat offers refuge from daily fluctuations in oxygen and temperature found on the shallower plateaus as well as better protection from aerial predators. Cast net sampling and anecdotal evidence from shrimp farmers indicated that shrimp and fish concentrate in the moats during the daytime and move over the shallows to feed at night. Prey become concentrated and readily available to wading birds within the moats when water levels are lowered to harvest shrimp. However, within 2-4 days after harvest, ponds are either left to dry, reflooded and left fallow, or reflooded and stocked with shrimp larvae, effectively becoming unproductive foraging habitat. Additionally, prey availability in shrimp ponds is subject to commercial market forces that dictate how shrimp farmers manage their animals and associated flora and fauna within the ponds, or 
whether the ponds are managed at all (e.g. ponds may be left empty for months while attempting to sell property or change management operations). In contrast, the natural estuary experiences twice-daily tidal fluctuations in water level, which do not typically leave large prey items concentrated in isolated pools, only small fish and shrimp. Natural mudflats in general offer a wider variety of foraging microhabitats on a daily basis than shrimp ponds, which are closed, non-tidal systems.

Seasonal differences in prey species diversity, density, and standing crop reflect differences in temperature, incident light, dissolved oxygen and salinity, and thus reproductive timing within the estuary (Taylor 1990). During the dry season at the study site lower temperatures, lowered incident light due to prolonged "garua" conditions (see Study Area above), and reduced rainfall increase salinity and likely decrease primary productivity due to lowered photosynthetic potential. These factors may have contributed to the observed lower prey biomass during the dry season relative to the wet season, when increased temperatures, incident light, and terrestrial runoff lowered salinities and may have increased primary productivity and availability of macroinfaunal prey to primary predators (Stoner and Acevedo 1990). Fish assemblages in tropical and subtropical estuaries in the Americas have been shown to increase in abundance and diversity during the wet season due to migration of larvae and juveniles of primarily marine and polyhaline species from offshore to nearshore environments (Faunce et al. 2004; Ley et al. 1999). The increase in prey biomass in the natural estuary during the wet season here was due in part to the presence of larger-sized ( $>5 \mathrm{~cm} \mathrm{TL}$ ) individual prey items that were not captured during the dry season. The presence of larger prey items during the wet season occurred either through increases in individual fish body size or 
through changes in the fish community toward larger-bodied species (Lorenz 1999). Since only two fish species (Daector dowii and Eleotris picta) were captured during the wet season that were not captured during the dry season, and sampled individuals were relatively small $(<3.2 \mathrm{~cm}$ TL for each species), the change in seasonal biomass was due to larger individual body sizes of the same species versus a shift in community composition. Additionally, all prey fish species captured can be considered estuarine residents tolerating mesohaline (5-17.99 ppt) and polyhaline (18-30 ppt) conditions and occurred within the study area throughout the year. This would indicate relatively little seasonal variation in species composition within the lower reaches of the estuary at shallow depths $(<40 \mathrm{~cm})$, despite significant differences in species diversity.

Increased hydroperiod due to freshwater input into mangrove areas of the southeastern saline Everglades during the wet season have resulted in greater densities of both small prey-base fish (<10 cm TL) and larger species (Faunce et al. 2004). A study of the demersal fish community in dwarf mangrove habitat (salinities $0-50 \mathrm{ppt}$ ) there revealed that fish biomass was negatively associated with higher mean salinity, and that both "prolonged periods of low salinity and high salinity variability... were correlated with increased biomass" (Lorenz 1999). However, biomass was not significantly different between mesohaline and polyhaline environments in the same study region of the Everglades (Lorenz and Serafy 2006), where mangrove habitats are largely non-tidally dominated and oligotrophic relative to the riverine mangrove system at the study site (Ewel 1998). Seasonal differences in biomass in Everglades mangroves may be more a function of hydrography, hydroperiod, and connectivity rather than salinity per se (Green et al. 2006; Faunce et al. 2004; Lorenz 1999). Although largely an invertebrate feeder, 
American flamingo food items increased in abundance during the wet season in the Celestun Lagoon in Yucatan, Mexico (Arrengo and Baldasarre 1999). In summary, abiotic and biotic conditions during the wet season generally become more favorable for the greatest number of oligo-, meso-, and euryhaline prey species within the study estuary. The increased diversity and availability of larger prey items during this time is likely the primary trigger of local wading bird breeding at the study site, an environmental cue apparently unaffected by the presence of shrimp ponds (Kushlan 1978; Butler 1993). The opposite is true of wading birds in the mangrove areas of south Florida, Venezuela, and Mexico, where wading birds breed during the dry season when prey availability increases in adjacent freshwater wetlands as water levels recede and concentrate prey in isolated pools with high prey density (Faunce et al. 2004; Ley et al. 1999; Lorenz 1999; Kushlan et al. 1985). Adjacent habitat at the study site is largely closed-canopy tropical wet forest or agricultural areas with densely vegetated freshwater streams with steep banks unsuitable as foraging habitat to the wading bird species examined here (Kushlan 1978).

The mean mass of individual prey items was significantly greater in shrimp ponds due to two primary factors; the lack of large secondary predators within the cyclical self-contained ponds, and the enhanced primary and secondary productivity resulting from supplemental feed and fertilizers. Nutrient enrichment (primarily phosphorous and nitrogen) in the Florida Everglades has been shown to increase species diversity and density of macroinvertebrates and small fish in freshwater wetlands (Rader and Richardson 1994). 
Species Diversity

Species diversity of prey items was greater in the estuary than in shrimp ponds.

This is attributed to the greater variety of microhabitats (e.g. spatial niches), immigration, and reproduction potential found in the open estuarine system relative to the ecologically isolated shrimp ponds where the 'founder effect' may play a role in limiting pond diversity (Mayr 1963). Since estuarine water pumped into the shrimp ponds after harvest events is typically filtered with fine-meshed $(\approx 3-5 \mathrm{~mm})$ screens (i.e. the 'founder event'), adult predatory fish and aquatic invertebrates are effectively excluded from the ponds at stocking time. Only a limited abundance of larvae, post-larvae and small juveniles of these species become the founder populations within the ponds and have only a $3-4$ month period for growth, maturation, and reproduction before the pond is harvested again. This amount of time may be insufficient for many species to complete their life cycle or even survive predation by larger, faster-growing predatory species that may have entered the pond at a more advanced stage of development. Additionally, the species composition of organisms being pumped into the ponds are coming from one pointsource location (i.e. the pond pump intake) that is associated with particular biotic and abiotic conditions (e.g. water depth, salinity, temperature, dissolved oxygen, turbidity, substrate type, aquatic macrophytes, etc.) that may further limit species diversity entering the ponds. Additionally, shrimp ponds have limited microhabitat variety with uniformly contoured pond bottoms and linear topography.

Species evenness was only slightly greater, but indicated a greater number of individuals of each representative species. Noteworthily absent from shrimp ponds were many species of juvenile fish (Daector dowi, Eleotris picta, M. curema, Sphoeroides 
annulatis, $P$. stylirostris, and Syacium ovale) and larval $P$. vannamei commonly found in the estuary. M. curema was the most preferred prey item of snowy egrets, and S. ovale was the second most preferred prey item of great egrets and neither were present in ponds. Noteworthily absent from natural mudflats was Centropomus sp., D. latifrons, $G$. liolepis, Haemulon sexfasciatum, Microgobius crocatus, M. curtus, M. embelematicus, and $P$. punctatus, several species of which reach larger maximum body size than those species trapped in the estuary. These species were likely found at greater depths in the natural estuary than in shrimp ponds, and were therefore not accessible with throw traps.

In conclusion, commercial shrimp ponds are the principal food source for breeding great and snowy egrets, and possibly black-crowned night herons, within the Muisne River Estuary. However, other diurnal wading birds within the community do not readily utilize shrimp ponds, indicating they are a poor ecological substitute for natural mangrove mudflats as foraging habitat for the resident wading bird community. As demonstrated in a variety of other human-modified wetlands and estuaries throughout the world (White and Main 2005; Richardson and Taylor 2003, Lane and Fujioka 1998; Young 1998; Elphick and Oring 1998; Frederick and McGehee 1994), each species in the wading bird community at the study site has been differentially impacted by anthropogenic change, in this case the construction of shrimp ponds.

Four species have undoubtedly benefited from the expansion of shrimp farming in coastal Ecuador; cattle egrets, black-crowned night herons, great egrets, and snowy egrets. The well-documented global range expansion of the now ubiquitous cattle egret over the past two centuries exemplifies the positive effects humans can have on wading birds. Destruction of former mangrove forests and increased area of terrestrial foraging 
habitat have facilitated the movement and reproduction of this highly adaptable species, an aggressive nest associate/competitor of other wading birds. Black-crowned night herons, a nocturnal crustacean specialist not studied here, is likely another species positively affected by the construction of shrimp farms. Not only would this species benefit from the greater abundance of $P$. vanname $i$ within the estuary system, but other crustaceans, such as fiddler and blue land crabs, may become more available due to an increase in the perimeter to area ratio of shorelines suitable for crab burrows. The great egret, a large cosmopolitan generalist, and the snowy egret, a versatile feeder, both exhibit behavioral and morphological adaptations suited to take advantage of anthropogenic landscapes such as aquaculture ponds in Northwest Ecuador. These species have readily adapted to foraging in shrimp ponds at the study site and shrimp ponds now appear to provide the primary food source during breeding. In contrast, the smaller and more specialized herons have not been able to capitalize on increased prey biomass concentrated in ponds because of reduced prey availability.

A comparison of the estimated mean energetic value (i.e. calories) of prey-base estuarine fish (Osteichthyes)(5.1 kcal/g)(Kushlan et al. 1986; Purcell 1981) and penaeid shrimp (5.2 kcal/g)(Peng et al. 2004; Odum and Arding 1991) indicates there is likely no significant difference between the two taxonomic groups at the study site. This is further evidence that great and snowy egrets are selectively foraging in shrimp ponds because of greater prey availability and individual prey item size rather than greater energetic content of prey items. Further, breeding success at the study colony is not likely to have been limited by energy availability prior to the influx of shrimp ponds because the natural estuary habitat appears to meet the estimated minimum daily energy requirements of both 
species during breeding (Parsons and Master 2000; Kushlan 1978). However, increased salt intake by wading birds consuming mostly penaeid shrimp (osmoconformers) relative to birds consuming mostly fish (osmoregulators) may affect reproductive success adjacent to shrimp farms due to the increased stress of osmotic regulation by both chicks and adults coping with elevated salt concentrations. However, both breeding success and previous breeding bird abundance within the estuary remain unknown.

Since shrimp ponds are a relatively recent arrival to coastal Ecuador, and there is a lack of historical data on wading bird populations throughout the region, it is unclear whether biotic homogenization through habitat modification is occurring at the study site. However, the cattle egret has contributed to the homogenization process among wading bird species by becoming established in the area and competing for nest sites with indigenous species. The range expansion of other non-indigenous species such as the northward spread of the Pacific hornero (Furnarius cinnamomeus) from southwest Ecuador have almost certainly been facilitated by the creation of shrimp farms and agricultural areas in the historically forested northern coast (Ridgely and Greenfield 2001). Although not studied here, habitat alteration effects on other species of birds observed at the study site may have favored aquatic and non-forest species such as shorebirds (Charadriifromes), neotropic cormorant, pied-billed grebe (Podilymbus podiceps), great tailed grackle (Quiscalus mexicanus), and others, at the expense of forest and inner-forest specialists such as rufous-necked wood-rail (Aramides axillaris), mangrove warbler (Dendroica petechia), black-throated mango (Anthracothorax nigricollis), red-legged honeycreeper (Cyanerpes cyaneus), and others (Appendix 1). Species presence data and opportunistic field observations collected during the study 
suggest that the abundance and diversity of migrant and resident shorebirds (Order Charadriiformes) may have been enhanced by shrimp pond construction in formerly forested areas unsuitable for foraging (Appendix 1). Most of these species prefer to forage on open unvegetated mudflats, conditions which likely would have been less abundant within former mangrove areas. Ultimately, the wading bird community, and bird community in general at the study site, may become dominated by overabundant generalist species and reduced in diversity and evenness. Comparing diversity of all bird species between shrimp farms and natural estuaries in coastal Ecuador is of future research interest.

Although anthropogenic habitats such as aquaculture facilities and refuse dumps may provide food and breeding colony locations for wading birds, they also experience reduced species diversity, heavier use by juvenile or nonreproductive individuals, and overabundant populations of generalist and invasive species (Chu 1995; Young 1998). These habitats are also subject to environmental contaminants (Custer 2000), disease outbreaks (Boyd and Green 2002; Durand 2000; Rodriguez et al. 2003), and habitat instability due to the variability of land management practices (Hafner 2000; Elphick, C. and L. Oring 1998; Lane and Fujioka 1998; Young 1998; Fasola et al. 1996; Breininger and Smith 1990). Long term stability and species-specific impacts of shrimp aquaculture in tropical landscapes may depend upon such factors as the species in cultivation, pond management practices (e.g. pesticide/herbicide usage), nuisance wildlife management activities, season, surface area, prey availability, and presence of adjacent suitable foraging habitat. 
Maintaining biodiversity is a worthy goal of conservation biology, therefore shrimp farms must be considered an inferior foraging habitat for wading birds in coastal Ecuador. To this end, mangrove forest should be restored when possible and active farms should be managed so as to maximize suitability for the greatest diversity of bird species (see Management Recommendations below). Unfortunately, the current dependence of great and snowy egrets on shrimp ponds within the estuary make the birds subject to rapidly changing aquacultural practices and global, regional, and local economic forces. Current threats include white spot disease and Taura syndrome, pesticide contamination, predator control activities, rapidly increasing use of greenhouse style enclosures over ponds, increased import tariffs on shrimp to industrialized nations (e.g. United States), and changes in global competition and demand for imported shrimp. 


\section{MANAGEMENT IMPLICATIONS}

Many shrimp ponds in the study area have been left fallow due to depressed shrimp markets or changes in ownership, and in some cases have been reverted to state ownership following illegal possession by shrimp farmers. It is recommended that the Ecuadorian Ministry of the Environment, in cooperation with local non-governmental organizations, manage these disturbed mangrove areas to maximize wading habitat quality within the Muisne River Estuary. Wading bird and wildlife viewing opportunities can create potentially profitable ecotourism ventures and enhance the local economy. Restoration and enhancement projects aimed at wading bird habitat can contribute to the conservation of lower trophic level estuarine organisms associated with mangrove mudflats such as commercially important species of mollusk (e.g. black cockle, mussels, oysters), crustacean (e.g. blue crabs, giant land crabs, white shrimp), and fish (e.g. snook, croakers, corvinas, weakfishes, threadfins, anchovies, and menhadens).

The perimeter berms of abandoned, fallow, or inactive shrimp ponds should be breached to allow natural tidal flushing to a maximum depth of $\approx 1$ meter during mean high tide. Pond contours should be re-graded to create gently sloping $(<15 \%$ grade) shorelines with water depths ranging from 5-20 cm extending approximately 5-30 meters from shore, or similarly, manipulate water levels (White et al. 2005). Restored/created wetlands in the U.S., that have similar contours to shrimp ponds in Ecuador, have met with success in attracting the endangered wood stork in various locations in South Carolina (Coulter 1990) and south Florida (Murdock 1987).

Data suggest that active shrimp ponds should eliminate predation control of wading birds. The maximum number of shrimp that were observed being removed from 
shrimp ponds during one observation period was by great egrets during a harvest event in the dry season $(5$ shrimp/minute, averaging $6 \mathrm{~cm}$ in total length and weighing approximately $1.5 \mathrm{~g}$ ), when water levels were drained to $<10 \mathrm{~cm}$. However, this level of prey capture was not sustained beyond the 1-minute observation period and was considered an extreme value in a pond where shrimp were ill with white spot disease and were particularly lethargic. A more conservative maximum prey capture rate of shrimp from shrimp ponds is estimated at 0.081 shrimp/minute, which equates to approximately $24 \mathrm{~kg} /$ pond/year, or $\$ 260 /$ year/pond in economic losses. This amount of loss to predation $(<2 \%)$ is insignificant relative to natural mortality rates (Draulans 1988). This loss is also minimal relative to local and international shrimp prices and annual productivity in most shrimp ponds (1,000-3,000 kg/pond/year). Additionally, all species of wading birds foraging in shrimp ponds at the study site, with the exception of great egrets, captured primarily fish, not shrimp, thereby partially offsetting losses by eliminating natural shrimp predators within the ponds. Therefore, predation control of 'nuisance' wading birds is unnecessary and unwarranted in the Muisne River estuary, and likely unnecessary along the entire coast of Ecuador.

It is recommended that the Ecuadorian Marine Corps better enforce the prohibition of new shrimp farm construction and mangrove loss to the expansion of existing farms. Farm owners can allow mangrove trees to establish along the banks of active shrimp ponds where possible. This not only offers roosting sites for wading birds and foraging habitat for migrant and resident forest dwelling species, but provides shoreline and berm stabilization around ponds perimeters. Finally, the use of pesticides to sterilize ponds after harvest events should be eliminated to prevent the increasingly 
common occurrance of fish kills within the estuary when contaminated waters are released back into the estuary. 


\section{LIST OF REFERENCES}

Alongi, D.M. 2002. Present state and future of the world's mangrove forests. Environmental Conservation 29(3): 331-349.

Andelt, W.F., T.P. Woolley, and S.N. Hopper. 1997. Effectiveness of barriers, pyrothecnics, flashing lights, and Scarey Man for deterring heron predation on fish. Wildlife Society Bulletin 25(3): 686-694.

Agarwal, D. K., A. E. Gelfand, and S. Citron-Pousty. 2002. Zero-inflated models with application to spatial count data. Environmental and Ecological Statistics 9:341355.

Arrengo, F. and G. Baldasarre. 1999. Resource variability and conservation of American flamingos in coastal wetlands of Yucatan, Mexico. Journal of Wildlife Management 63(4): 1201-1212.

Arriaga, L., M. Montana, and J. Vasconez. 1999. Integrated management of the Bahia de Caraquez zone and Chone River estuary, Ecuador. Ocean and Coastal Management 42: 229-241.

Avery, M., D. Eiselman, M. Young, J. Humphrey, and D. Decker. 1999. Wading bird predation at tropical aquaculture facilities in central Florida. North American Journal of Aquaculture 61(1): 64-69.

Bancroft , G.T., A.M. Strong, R.J. Sawicki, W. Hoffman, and S.D. Jewell. 1997. Relationships among wading bird foraging patterns, colony locations, and hydrology in the Everglades. Pages 615-657 in Everglades. The ecosystem and its restoration. Davis, S.M. and J.C. Ogden, editors. St. Lucie Press, Boca Raton.

Barry, S. C., and A. H. Welsh. 2002. Generalized additive modelling and zero inflated count data. Ecological Modelling 157:179-188.

Bayer, Range D. 1985. Bill length of herons and egrets as an estimator of prey size. Colonial Waterbirds 8(2): 104-109.

Beutel, T. S., R. J. S. Beeton, and G. S. Baxter. 1999. Building better wildlife-habitat models. Ecography 22:219-223.

Bildstein, K.L., D.E. Gawlik, D.P. Ferral, I.L. Brisbin, G.R. Wein. 1994. Wading bird use of established and newly created reactor cooling reservoirs at the Savanna-River site, near Aiken, South Carolina, USA. Hydrobiologia 280: 71-82. 
Bildstein, K., G.T. Bancroft, P.J. Dugan, D.H. Gordon, R.M. Erwin, E. Nol, L.X. Payne, and S. Senner. 1991. Approaches to the conservation of coastal wetlands in the Western Hemisphere. Wilson Bulletin 103(2): 218-254.

Blanchard, J. and G. Prado. 1995. Natural regeneration of Rhizophora mangle in strip clearcuts in northwest Ecuador. Biotropica 27 (2): 160-167.

Blanco, G. and R. Rodriguez-Estrella. 1998. Human activity may benefit white-faced ibises overwintering in Baja California Sur, Mexico. Colonial Waterbirds 21(2): 274-276.

Bollinger, E.K. and P. Switzer. 2002. Modeling the impact of edge avoidance on avian nest densities in habitat fragments. Ecological Applications 12(6): 1567-1575.

Boyd, C. and B.W. Green. 2002. Coastal Water Quality Monitoring in Shrimp Farming Areas: An Example from Honduras. Auburn University Press, Auburn, Alabama.

Breininger, D.R. and R.B. Smith. 1990. Waterbird use of coastal impoundments and management implications in east-central Florida. Wetlands 10(2): 223-239.

Brush, T, R.A. Lent, T. Hruby, B. Harrington, R. Marshall, and W. Montgomery. 1986. Habitat use by salt marsh birds and response to open marsh water management. Colonial Waterbirds 9(2): 189-195.

Burger, J., J. Shisler, and F.H. Lesser. 1982. Avian utilization on six salt marshes in New Jersey. Biological Conservation 23(3): 187-212.

Butler, R.W. 1993. Time of breeding in relation to food availability of female Great Blue Herons. Auk 110: 693-701.

Carrera, P.U., P.G. Jiménez, and X. Viteri. 2001. Terrestrial Ecoregions of the WorldManabí mangroves (NT1418). World Wildlife Fund. Website accesses 8/17/04. http://www.worldwildlife.org/wildworld/profiles/terrestrial/nt/nt1418_full.html

CEPF, 2001. Ecosystem Profile: Chocó-Manabi Corridor, Chocó-Darién-Western Ecuador. Conservation International, Critical Ecosystem Partnership Fund. Website accessed 8/23/04. http://www.cepf.net/xp/cepf/where_we_work/choco_darien/full_strategy.xml\#bio logical

Cezilly, F. 1992. Turbidity as an ecological solution to reduce the impact of fish-eating colonial waterbirds on fish farms. Colonial Waterbirds 15(2): 249-252.

Chu, W.H. 1995. Fish ponds in the ecology of the inner Deep Bay wetlands of Hong Kong. Asian Journal of Environmental Management 3(1): 13-36. 
CLIRSEN. 1999. Sanchez, R. and G. Moran, eds. Actualizacion del estudio multitemporal de los manglares, camaroneras, y areas salinas del Ecuador continental a 1999 con base a informacion satelitaria.

Coulter, M.C. 1990. Creation and management of artificial foraging habitat for wood storks. New York State Museum Bulletin 471: 262-267.

Crozier, G.E., and D.E. Gawlik, eds. 2003. South Florida wading bird report. Vol. 9. South Florida Water Maangement District. West Palm Beach, FL.

Cunningham, R. B., and D. B. Lindenmayer. 2005. Modeling count data of rare species: Some statistical issues. Ecology 86: 1135-1142.

Custer, Thomas W. 2000. Environmental contaminants. Pp. 251-267 in: Kushlan, J. and Hafner, H. (eds.). Heron Conservation. Academic Press. New York, NY.

Davis, S. editor. 2001. CERP monitoring and assessment plan. in revision. South Florida Water Management District, West Palm Beach, FL.

Dittel, A.I., C. Epifanio, L. Cifuentes, and D.L. Kirchman. 1997. Carbon and nitrogen sources for shrimp port-larvae fed natural diets from a tropical mangrove system. Estuarine, Coastal, and Shelf Science 45: 629-637.

Dobbie, M. J., and A. H. Welsh. 2001. Modelling correlated zero-inflated count data. Australian \& New Zealand Journal of Statistics 43:431-444.

Dodson, C.H. and A.H. Gentry. 1991. Biological extinction in western Ecuador. Annals of the Missouri Botanial Garden 78: 273-295.

Donovan, T.M. and R.H. Lamberson. 2001. Area sensitive distributions counteract negative effects of habitat fragmentation on breeding birds. Ecology 82(4): 11701179 .

Draulans, D. 1988. Effects of fish-eating birds on freshwater fish stocks: an evaluation. Biological Conservation 44(4): 251-263.

Durand, S., K. F. J. Tang, and D. V. Lightner. 2000. Frozen Commodity Shrimp: Potential Avenue for Introduction of White Spot Syndrome Virus and Yellow Head Virus. Journal of Aquatic Animal Health 12:128-135.

Dusi, J.L. and R.D. Dusi. 1978. Survey methods used for wading birds studies in Alabama. Pages 207-212 in Wading birds: research report No.7 of the National Audubon Society. Sprunt IV, A., J.C. Ogden, and S. Winckler, editors. National Audubon Society, NY. 
Edelson, N.A. 1990. Foraging ecology of wading birds using an altered landscape in central Florida. M.S. Thesis. University of Florida, Gainesville.

Ellison, A.M. and E.J. Farnsworth. 1996. Anthropogenic disturbance of Caribbean mangrove ecosystems: past impacts, present trends, and future predictions. Biotropica 28 (4a): 549-565.

Elphick, C. and L. Oring. 1998. Winter management of Californian rice fields for Waterbirds. Journal of Applied Ecology 35(1): 95-108.

Elphick, C.S. 2000. Functional equivalency between rice fields and semi-natural wetland habitats. Conservation Biology 14(1): 181-191.

Epstein, M.S., and R.L. Joyner. 1986. Use of managed and open tidal marsh by waterbirds and alligators. Pages 529-579 in South Carolina coastal wetland impoundments: Ecological characterization, management, status and use. Volume II: Technical Synthesis. Publication No. SC-SG-TR-86-2. DeVoe, M.R. and D.S. Baughman, eds. South Carolina Sea Grant Consortium. Charleston, SC.

Erwin, M.R. 1983. Feeding habitats of nesting wading birds: spatial use and social Influences. The Auk 100: 960-970.

Erwin, M. 1985. Foraging decisions, patch use, and seasonality in egrets (Aves: Ciconiiformes). Ecology 66(3): 837-844.

Erwin, M.R., M. Coulter, and H. Cogswell. 1986. The use of natural vs. man-modified wetlands by shorebirds and waterbirds. Colonial Waterbirds 9(2): 137-138.

Erwin, R. Michael, and T. Custer. Herons as indicators. In: Kushlan, J. and Hafner, H. (eds.). Heron Conservation. Academic Press. New York, NY.

Esler, D. 1992. Habitat use by piscivorous birds on a power plant cooling reservoir. Journal of Field Ornithology 63(3): 241-392.

Ewel, K., R.R. Twilley, and J.E. Ong. 1998. Different kinds of mangrove forests provide different goods and services. Global Ecology and Biogeography Letters 7: 83-94.

Fasola, M. 1986. Resource use of foraging herons in agricultural and non-agricultural habitats in Italy. Colonial Waterbirds 9: 139-148.

Fasola, M. and X. Ruiz. 1996. The value of rice fields as substitutes for natural wetlands for waterbirds in the Mediterranean region. Colonial Waterbirds 19 (Special Publication 1): 122-128. 
Fasola, M., L. Canova, and N. Saino. 1996. Rice fields support a large portion of herons breeding in the Mediterranean region. Colonial Waterbirds 19: 129-134.

Faunce, C., J. Serafy, and J. Lorenz. 2004. Density-habitat relationships of mangrove creek fishes within the southeastern saline Everglades (USA), with reference to managed freshwater releases. Wetlands Ecology and Management 12: 377-394.

Fletcher, D., D. MacKenzie, and E. Villouta. 2005. Modelling skewed data with many zeros: A simple approach combining ordinary and logistic regression. Environmental and Ecological Statistics 12:45-54.

Fleury, B.E., and T.W. Sherry. 1995. Long-term population trends of colonial wading birds in the southern United States: The impact of crayfish aquaculture on Loiusiana populations. Auk 112(3): 613-632.

Frederick, P. and K. Bildstein. 1992. Foraging ecology of seven species of neotropical ibises (Threskiornithidae) during the dry season in the llanos of Venezuela. Wilson Bulletin 104(1): 1-21.

Frederick, P.C. and S. McGehee. 1994. Wading bird use of wastewater treatment wetlands in central Florida, USA. Colonial Watebirds 17(1): 50-59.

Frederick, P.C. and J. C. Ogden 2003. Monitoring wetland ecosystems using avian populations: Seventy years of survey and research in the Everglades. In: D. Busch and J. Trexler (eds). Interdisciplinary approaches to ecological monitoring of major ecosystem restoration initiatives. Washington DC, Island Press.

Frederick, P. and M.G. Spalding. 1997. Factors affecting reproductive success of wading birds (Ciconiiformes) in the Everglades ecosystem. Pages 659-691 in Everglades. The ecosystem and its restoration. Davis, S.M. and J.C. Ogden, editors. St. Lucie Press, Boca Raton, FL.

Frederick, P.C. 2002. Wading birds in the marine environment. Pages. 617-655 in Biology of Marine Birds. E.A. Schreiber and Joanna Burger, editors. CRC Press, Boca Raton, FL.

Gannes, L.Z., D.M. O'Brien, and C. Martinez del Rio. 1997. Stable isotopes in animal ecology: assumptions, caveats, and a call for more laboratory experiments. Ecology 78 (4): 1271-1276.

Gawlik, D.E. 2002. The effects of prey availability on the numerical response of wading birds. Ecological Monographs 72 (3): 329-346. 
Glahn, J.F., D. Reinhold, and P. Smith. 1999. Wading bird depredations on channel catfish (Ictalurus punctatus) in northwest Mississippi. Journal of the World Aquaculture Society 30(1): 107-114.

Green, D., J. Trexler, J. Lorenz, C. McIvor, and T. Philippi. 2006. Spatial patterns of fish communities along two estuarine gradients in southern Florida. Hydrobiologia 569: 387-399.

Hafner, H. 2000. Herons in the Mediterranean. Pp. 33-54 in Kushlan, J. and Hafner, H. (eds.). Heron Conservation. Academic Press. New York, NY.

Hafner, H. V. Boy, and G. Gory. 1982. Feeding methods, flock size, and feeding success in the little egret Egretta garzetta and the squacco heron Ardeiola ralloides in Camargue, southern France. Ardea 70: 45-54.

Hafner, H., P.J. Dugan, and Vincent Boy. 1986. Use of artificial and natural wetlands as feeding sites by little egrets (Egretta garzetta L.) in the Camargue, southern France. Colonial Waterbirds 9(2): 149-154.

Hafner, H. 1997. Ecology of wading birds. Colonial Waterbirds 20 (1): 115-120.

Hall, D. B. 2000. Zero-inflated Poisson and binomial regression with random effects: A case study. Biometrics 56:1030-1039.

Hamilton, L.S. and S.C. Snedaker. 1984. Handbook for mangrove area management, 123 pp. East-West Center, Honolulu HI, USA.

Harling, G. 1986. Current Scandinavian Botanical Research in Ecuador. Rep. Botanical Institute, Univ. Aarhus 15: 9-10.

Haverschmidt, F. 1965. The utilization of mangroves by South American birds. Ibis 107: 540-542.

Hayek, L. and M. Buzas. 1997. Surveying Natural Populations. Columbia University Press, New York.

Heilbron, D. C. 1994. Zero-Altered and Other Regression-Models for Count Data with Added Zeros. Biometrical Journal 36:531-547.

Hoffman, W., G.T. Bancroft, and R.J. Sawicki. 1994. Foraging habitat of wading virds in the water conservation areas of the Everglades. Pages 585-614 in Everglades. The ecosystem and its restoration. Davis, S.M. and J.C. Ogden, editors. St. Lucie Press, Boca Raton, FL.

Holdridge, L. R. 1967. Life zone ecology. Tropical Science Center, San Jose, Costa Rica. 
Horn, C.W. 1983. Foraging ecology of herons in a Southern San Francisco Bay salt marsh. Colonial Waterbirds 6: 37-44.

INAMHI, 2002. Weather station database for Port of Muisne, Ecuador. Instituto Nacional de Meteorologia e Hidrologia. Data provided by Jorge Celi, Florida International University, Miami, FL. http://www.inamhi.gov.ec/

INOCAR, 2004. Tabla de mareas del Ecuador-Puerto de Muisne. Productos Hidrograficos: Instituto Oceanografico de la Armada del Ecuador. Website accessed 8/5/04. http://www.inocar.mil.ec/product/marea.php

Jacobs, J. 1974. Quantitative measurement of food selection: A modification of the forage ratio and Ivlev's Electivity Index. Oecologia 14: 413-417.

Jenni, D.A. 1969. A study of the ecology of four species of herons during the breeding season at Lake Alice Alachua County, Florida. Ecological Monographs 39 (3): 245-270.

Joe, H., and R. Zhu. 2005. Generalized Poisson distribution: the property of mixture of Poisson and comparison with negative binomial distribution. Biometrical Journal 47:219-229.

Jones, A.B., M.J. O'Donohue, J. Udy, and W. Dennison. 2001. Assessing ecological impacts of shrimp and sewage effluent: Biological indicators with standard water quality analyses. Estuarine, Coastal, and Shelf Science 52: 91-109.

Julian, M. and J. Thiollay. 1996. Effects of rain forest disturbance and fragmentation: comparative changes of the raptor community along natural and human-made gradients in French Guiana. Journal of Biogeography 23: 7-25.

King, D.T., and D. LeBlanc. 1995. Foraging behaviors of snowy egrets (Egretta thula) and yellow-crowned night herons (Nyctanassa violacea) in south Louisiana. Colonial Waterbirds 18(2): 224-225.

Klimkiewicz, Kathy. 2004. Personal communication via e-mail. Biologist, USGS Patuxent Wildlife Research Center, Bird Banding Laboratory, Laurel, Maryland.

Kushlan, J. A. 1978. Feeding ecology of wading birds. Pages 249-297 in Wading Birds. Sprunt, A. IV, J.S. Ogden, and S. Winckler, editors. Res. Rep. 7, National Audubon Society, New York.

Kushlan, J. A. 1981. Resource use strategies of wading birds. Wilson Bulletin 93: 145-163. 
Kushlan, J. A. 1981. Sampling characteristics of enclosure fish traps. Transactions of the American Fisheries Society 110: 557-562.

Kushlan, J., G. Morales, and P. Frohring. 1985. Foraging niche relations of wading birds in tropical wet savannas. Ornithological Monographs 36: 663-682.

Kushlan, J., S. Voorhees and W. Loftus. Length, mass, and caloric relationships of Everglades animals. Florida Scientist 49: 65-79.

Kushlan, J.A. 1993. Colonial waterbirds as bioindicators of environmental change. Colonial Waterbirds 16(2): 223-251.

Lane, S.J., and M. Fujioka. 1998. The impact of changes in irrigation practices on the distribution of foraging egrets and herons (Ardeidae) in the rice fields of central Japan. Biological Conservation 83(2): 221-230.

Lefebvre, G., and B. Poulin. 1997. Bird communities in Panamanian black mangroves: potential effects of physical and biotic factors. Journal of Tropical Ecology 13: 97-113.

Lewis, R.R.III, R.G. Gilmore, Jr., D.W. Crewz, and W.E. Odum. 1985. Mangrove habitat and fishery resources of Florida. Pp. 281-336 in W. Seaman, Jr., ed. Florida aquatic habitat and fishery resources. Florida Chapter, Am. Fish. Soc., Gainesville, Florida.

Lewis, R.R. III, M.J. Phillips, B. Clough and D.J. Macintosh. 2003. Thematic Review on Coastal Wetland Habitats and Shrimp Aquaculture. Report prepared under the World Bank, NACA, WWF and FAO Consortium Program on Shrimp Farming and the Environment. Work in Progress for Public Discussion. Published by the Consortium. $81 \mathrm{pp}$.

Ley, J., C. McIvor, and C. Montague. 1999. Fishes in mangrove prop-root habitats of Northeastern Florida Bay: Distinct assemblages across and estuarine gradient. Estuarine, Coastal and Shelf Science 48: 701-723.

Lorenz, J. and J. E. Serafy. 2006. Subtropical wetland fish assemblages and changing salinity regimes: implications for Everglades restoration. Hydrobiologia 569: 401422.

Lorenz, J., J. Ogden, R. Bjork, and G. Powell. 2002. Nesting patterns of roseate spoonbills in Florida Bay 1935-1999: implications of landscape scale anthropogenic impacts. Pages 563-606 in The Everglades, Florida Bay, and coral reefs of the Florida keys. An ecosystem sourcebook. Porter, J. W. and K.G. Porter, editors. CRC Press, Boca Raton. 
Lorenz, J. 1999. The response of fishes to physiochemical changes in the mangroves of northeast Florida Bay. Estuaries 22(2B): 500-517.

Lynch, J.C., J.R. Meriwether, B.A. McKee, F. Vera-Herrera, and R.R. Twilley. 1989. Recent accretion in mangrove ecosystems based on ${ }^{137} \mathrm{Cs}$ and ${ }^{210} \mathrm{~Pb}$. Estuaries 12: 284-299.

Maehr, D.S. 1981. Bird use of a north-central Florida Phosphate Mine. Florida Field Naturalist 9(2): 28-32.

Marini, M.A. 2001. Effects of forest fragmentation on birds of the cerrado region, Brazil. Bird Conservation International 11(1): 13-25.

Marion, Loic. 2000. Aquaculture. In: Kushlan, J. and Hafner, H. (eds.). Heron Conservation. Academic Press. New York, NY.

Martin, T. G., B. A. Wintle, J. R. Rhodes, P. M. Kuhnert, S. A. Field, S. J. Low-Choy, A. J. Tyre, and H. P. Possingham. 2005. Zero tolerance ecology: improving ecological inference by modelling the source of zero observations. Ecology Letters 8:1235-1246.

Mayr, E. 1963.Animal species and evolution. Harvard University Press. Cambridge, MA.

McCrimmon, D.A., J.C. Ogden, and G.T. Bancroft. 2001. Great egret, Ardea alba (Ciconiiformes: Ardeidae). The Birds of North America 570: 1-32. American Ornithologists Union, Washington, D.C.

McGarigal, K. and S.A. Cushman. 2002. Comparative evaluation of experimental approaches to the study if habitat fragemtnation effects. Ecological Applications 12 (2): $335-345$.

McNeil, R., O. Diaz, I. Linero, and J. Rodriguez. 1995. Day- and night-time prey availability for waterbirds in a tropical lalgoon. Canadian Journal of Zoology 73: 869-878.

Meyers, N., R.A. Mittermeier, C.G. Mittermeier, G.A.B. da Fonesca, and J. Kent. 2000. Biodiversity hotspots for conservation priorities. Nature 403: 853-858.

Miranda, L. and J.A. Collazo. 1997. A modified throw-trap to sample prey for wading bird studies. Journal of Field Ornithology 68(4): 602-606.

Miranda, L. and J.A. Collazo. 1997. Food habits of 4 species of wading birds (Ardeidae) in a tropical mangrove swamp. Colonial Waterbirds 20 (3): 413-418. 
Mizutani, H., M. Fukuda, and Y. Kabaya. 1992. ${ }^{13} \mathrm{C}$ and ${ }^{15} \mathrm{~N}$ enrichment factors of feathers of 11 species of adult birds. Ecology 73 (4): 1391-1395.

Morales, G. and J. Pacheco. 1986. Effects of diking of a Venezuelan savanna on avian habitat species diversity, energy flow, and mineral flow through wading birds. Colonial Waterbirds 9(2): 236-242.

Mott, D.F. and R.D. Flynt. 1995. Evaluation of an electric fence system for excluding wading birds at catfish ponds. Progressive Fish Culturist 51(1): 88-90.

Murdock, N.A. 1987. Creation of artificial foraging habitat for wood storks. Endangered Species Technical Bulletin Vol. XII(1): 4;16. Wahington, D.C.

Neu, C., C. Byers, and J. Peek. 1974. A technique for analysis of utilization-availability data. Journal of Wildlife Management 38(3): 541-545.

Odum, W.E., C. McIvor, and T.J. Smith. 1982. The ecology of the mangroves of south Florida: a community profile. National Coastal Ecosystems Team, Fish and Wildlife Service, U.S. Department of the Interior and New Orleans OCS Office, Bureau of Land Management. Washington, D.C.

Odum, W.E. and C.C. McIvor. 1990. Mangroves. Chapter 15 in Ecosystems of Florida. R.L. Myers and John J. Ewel, editors. University of Central Florida Press, Orlando.

Odum, H. and J. Arding. 1991. Pp. 114. Emergy analysis of shrimp mariculture in Ecuador. Environmental Engineering Sciences and Center for Wetlands. University of Florida, Gainesville.

Ogden, J. 1985. Use of man-made impoundments as nesting sites by wood storks in Florida. Colonial Waterbird Group Newsletter. Williamsburg, VA.

Ogden, J.C. 1994. A comparison of wading bird colony dynamics (1931-1946 and 19741989) as an indication of ecosystem conditions in the southern everglades. Pages 533-570 in Everglades. The ecosystem and its restoration. Davis, S.M. and J.C. Ogden, editors. St. Lucie Press, Boca Raton.

Pacheco, D.C. Shrimp farms in Ecuador. Monografias.com. Website accessed 6/20/04. http://www.monografias.com/trabajos I5/shrimp-farms/shrimp-farms.shtml\#top

Palmer, R. S. 1962. Handbook of North American Birds, Vol. I. New Haven, Connecticut, Yale University Press. 
Parkinson, R.W., R.D. DeLaune, and J.R. White. 1994. Holocene sea-level rise and the fate of mangrove forests within the wider Carribean region. Journal of Coastal Resources 10: 1077-1086.

Parsons, K.C. and T.L. Master. 2000. Snowy egret, Egretta thula (Ciconiiformes: Ardeidae). The Birds of North America, Vol. 489: 1-24. American Ornithologists Union, Washington, D.C.

Parsons, K.C. 2002. Integrated management of waterbird habitats at impounded wetlands in Delaware Bay, U.S.A. Waterbirds 25 (Special Publication 2): 25-41.

Peng, L., X. Wang, R. Hardy, and D. Gatlin. 2004. Nutritional value of fisheries by-catch and by-product meals in the diet of red drum (Sciaenops ocellatus). Aquaculture 236: 485-496.

Podlich, H. M., M. J. Faddy, and G. K. Smyth. 2002. A general approach to modeling and analysis of species abundance data with extra zeros. Journal of Agricultural Biological and Environmental Statistics 7:324-334.

Powell, G.V.N. 1987. Habitat use by wading birds in a subtropical estuary: implications of hydrography. The Auk 104: 740-749.

Purcell, J. 1981. Feeding Ecology of Rhyzophysa eysenhardti, a siphonophore predator of fish larvae. Limnology and Oceanography 26(3): 424-432.

Rader, R. and C. Richardson. 1994. Response of macroinvertebrates and small fish to nurient enrichment in the northern Everglades. Wetlands 14(2): 134-146.

Ramo, C. and B. Busto. 1993. Resource use by herons in a Yucatan wetland during the breeding season. Wilson Bulletin 105(4): 573-586.

Renfrow, D.H. 1993. The effects of fish density on wading burd use of sediment ponds in an east Texas coal mine. M.S. Thesis. Texas A \& M University.

Richardson, A.J., I.R. Taylor, and J.E. Growns. 2001. The foraging ecology of egrets in rice fields in southern New South Wales, Australia. Waterbirds 24(2): 255-264.

Richardson, A.J., and I.R. Taylor. 2003. Are rice fields in southeastern Australia an adequate substitute for natural wetlands as foraging areas for egrets? Waterbirds 26(3): 353-363.

Ridgely, R.S., and P.Greenfield. 2001. The birds of Ecuador. Vols. I and II. Cornell University Press. Ithaca, NY. 
Rodríguez, J., B. Bayot, Y. Amano, F. Panchana, I. de Blas, V. Alday and J Calderón. 2003. White spot syndrome virus infection in cultured Penaeus vannamei (Boone) in Ecuador with emphasis on histopathology and ultrastructure. Journal of Fish Diseases 26(8): 439-

Rolstad, J., I. Gjerde, V.S. Gundersen, and M. Saetersdal. 2000. Use of indicator species to assess forest continuity: a critique. Conservation Biology 16 (1): 253-257.

Sheridan, P. and C. Hays. 2003. Are mangroves nursery habitat for transient fishes and Decapods? Wetlands 23(2): 449-458.

Snedaker, S. and A. Lugo. 1973. The role of mangrove ecosystems in the maintenance of environmental quality and a high productivity of desirable fisheries. U.S. Bureau of Sports, Fisheries, and Wildlife. NTIS. Springfield, VA.

Sonnenholzer, S. and C. Boyd. 2000. Chemical and physical properties of shrimp pond bottom soils in Ecuador. Journal of the World Aquaculture Society 31(3): 358375 .

Spanier, E. 1980. The use of distress calls to repel night herons (Nycticorax nycticorax) from fish ponds. The Journal of Applied Ecology 17(2): 287-294.

Stattersfield, A. 1998. Endemic bird areas of the world : priorities for biodiversity conservation. BirdLife International. Cambridge, UK.

Stoner, A.W. and C. Acevedo. 1990. The Macroinfaunal Community of a Tropical Estuarine Lagoon. Estuaries 13(2): 174-181.

Stotz, D.F., J.W. Fitzpatrick, T.A. Parker, D.K. Moskovits. 1996. Neotropical birds. Ecology and conservation. University of Chicago Press, Chicago.

Sykes, P.W. and G.S. Hunter. 1978. Bird use of flooded agricultural fields during summer and early fall and some recommendations for management. Florida Field Naturalist 6(2): 36-43.

Taylor, M.H. 1990. Estuarine and intertidal teleosts. Pages 109-124 in Reproductive Seasonality in Teleosts: Environmental Influences. CRC Press, Boca Raton, Florida.

Telfair, R. 1994. Cattle egret (Bubulcus ibis). In Birds of North America, No. 113 (A. Poole and F. Gill, Eds.). Philidelphia: The Academy of Natural Sciences; Washington D.C.; The American Ornithologists' Union.

Temple, S.A., J.R. Cary. 1988. Modeling dynamics of habitat-interior bird populations in fragmented landscapes. Conservation Biology 2(4): 339-347. 
Temple, S.A. and J.A Wiens. 1989. Bird populations and environmental changes: can birds be bio-indicators? American Birds 43: 260-270.

Twilley, R.R., A. Bodero, and D. Robadue. 1993. Mangrove ecosystem biodiversity and conservation in Ecuador. Pages 105-127 in Perspectives on biodiversity: case studies of genetic resource conservation and development. Potter, C.S., J.J. Cohen, and D. Janczewski, editors. AAAS, Washington D.C.

UNCSD, 1997. Bill of Particulars, Version 1.2. The Shrimp Tribunal session at the United Nations Commission on Sustainable Development. Website accessed 8/22/04. http://www.earthsummitwatch.org/shrimp/

USDA, 1999. Outbreak of Shrimp Viral Disease in Central America: Situation Report. Animal and Plant Health Inspection Service (APHIS), Veterinary Services, National Aquaculture Program, Services for the Aquaculture Industry, U.S. Department of Agriculture (USDA). Website accessed 8/23/04. http://www.aphis.usda.gov/vs/aqua/wssv.html.

USDS, 2004. Background Note: Ecuador. Bureau of Western Hemisphere Affairs, United States Department of State. Website accessed 8/23/04. http://www.state.gov/r/pa/ei/bgn/2906.htm

Valiela, I., J. Bowen, and J. York. 2001. Mangrove forests: one of the world's threatened major tropical environments. Bioscience 51 (10):807-815.

Velasquez, C.R. 1992. Managing artificial saltpans as a waterbird habitat - species responses to water level manipulation. Colonial Waterbirds 15(1): 43-45.

Watson, D.M. 2003. Long-term consequences of habitat fragmentation-highland birds in Oaxaxca, Mexico. Biological Conservation 111(3): 283-303.

Wege, D.C. and A.J. Long. 1995. Key areas for threatened birds in the neotropics, Birdlife Conservation Series No. 5. Birdlife International, Washington D.C.

Welsh, A. H., R. B. Cunningham, C. F. Donnelly, and D. B. Lindenmayer. 1996. Modelling the abundance of rare species: Statistical models for counts with extra zeros. Ecological Modelling 88:297-308.

Welsh, A. H., R. B. Cunningham, and R. L. Chambers. 2000. Methodology for estimating the abundance of rare animals: Seabird nesting on North East Herald Cay. Biometrics 56:22-30. 
Werner, S.I., D.T. King, J.F. Glahn, and J.V. Hunter. 2000. Colonial waterbirds and north American aquaculture. U.S. Department of Agriculture (USDA), National Wildlife Research Center, Mississippi Field Station, Mississippi State University. Mississippi. Website accesses 5/5/04. www. waterbirdconservation.org/plan/rptaquaculture2.pdf

Werner, S., M. Tobin, and P. Fioranelli. 2001. Great egret preference for catfish size classes. Waterbirds 24(3): 381-385.

Willard, D.E. 1977. The feeding ecology and behavior of five species of herons in southeastern New Jersey. The Condor 79: 462-470.

White, C., P. Frederick, M. Main, and J. Rogers. 2005. Nesting island creation for wading birds. Wildlife Ecology and Conservation Department, Florida Cooperative Extension Service, Institute of Food and Agricultural Sciences, University of Florida. Circular 1473. EDIS Web site visited on 9/1/05 at http://edis.ifas.ufl.edu.

White, C. and Main, M. 2005. Waterbird use of created wetlands in golf-course landscapes. Wildlife Society Bulletin 33(2): 411-421.

Woltmann, S. 2003. Bird community responses to disturbance in a forestry concession in lowland Bolivia. Biodiversity and Conservation 12: 1921-1936.

Young, L. 1998. The importance to Ardeids of the Deep Bay fish ponds, Hong Kong. Biological Conservation 84(3): 293-300.

Zar, J.H. 1999. Biostatistical analysis. Prentice Hall, New Jersey, 663 pp. 
Appendix 1. Bird species observed within the Muisne River Estuary, Esmeraldas, Ecuador during the study period (2004-2005)

*= Asterisk indicates that species was also observed utilizing shrimp ponds in some capacity (i.e. resting, feeding, roosting, nesting, flying over, etc.)

Common Name

Blue-footed booby

Brown pelican

Neotropic cormorant

Magnificent frigatebird

Striated heron

Snowy egret

Little blue heron

Tricolored heron

Black-crowned night heron

Yellow-crowned night heron

Cattle egret

Cocoi heron

Great egret

White ibis

Pied-billed grebe

Black-bellied whistling duck

White-cheeked pintail

Blue-winged teal

Turkey vulture

Black vulture

Osprey

White-tailed kite

Peregrine falcon

Rufous-headed chachalaca

Rufous-necked wood-rail

Common gallinule

American oystercatcher

Gray plover

Whimbrel

Willet

\section{$\underline{\text { Scientific Name }}$}

Sula nebouxii

Pelicanus occidentalis

Phalacrocorax brasilianus

Fregata magnificens

Butorides striatus

Egretta thula

Egretta caerulea

Egretta tricolor

Nycticorax nycticorax

Nyctanassa violacea

Bulbulcus ibis

Ardea cocoi

Ardea alba

Eudicimus albus

Podilymbus podiceps

Dendrocygna autumnalis

Anas bahamensis

Anas discors

Cathartes aura

Coragyps atratus

Pandion haliaetus

Elanus leucurus

Falco peregrinus

Ortalis erythoptera

Aramides axillaris

Gallinula chloropus

Haematopus palliatus

Pluvialus squatarola

Numenius phaeopus

Catoptrophorus semipalmatus 
Black-necked stilt

Snowy plover

Collared plover

Wilson's plover

Least sandpiper

Sanderling

Pectoral sandpiper

Ruddy turnstone

Spotted sandpiper

Lesser yellowlegs

Short-billed dowitcher

Royal tern

Blue-headed parrot

Smooth-billed ani

Groove-billed ani

Striped cuckoo

Pacific pygmy-owl

Anthony's nightjar

White-collared swift

Black-throated mango

Lineated woodpecker

Ringed kingfisher

Green kingfisher

Green and rufous kingfisher

Pacific hornero

Vermillion flycatcher

Masked water-tyrant

Tropical kingbird

Grey-breasted martin

Blue and white swallow

Southern rough-winged swallow

Barn swallow

House wren

Mangrove warbler

Bananaquit

Red-legged honeycreeper

Blue-grey tanager

Lemon-rumped tanager

Blue-black grassquit
Himantopus mexicanus

Charadrius alexandrinus

Charadrius collaris

Charadrius wilsonia

Calidris minutilla

Calidris alba

Calidris melanotos

Arenaria interpres

Actitis macularia

Tringa flavipes

Limnodromus griseus

Sterna maxima

Pionus menstruus

Crotophaga ani

Crotophaga sulcirostris

Tapera naevia

Glacidium peruanum

Caprimulgus anthonyi

Streptoprocne zonaris

Anthracothorax nigricollis

Dryocopus lineatus

Megaceryle torquata

Chloroceryle americana

Chloroceryle inda

Furnarius cinnamomeus

Pyrocephalus rubinus

Fluvicola nengeta

Tyrannus melacholicus

Progne chalybea

Notiochelidon cyanoleuca

Stelgidopterix ruficollis

Hirundo rustica

Troglodytes aedon

Dendroica petechia

Coereba flaveola

Cyanerpes cyaneus

Thraupis episcopus

Ramphocelus icteronotus

Volatinia jacarina
*

*

$*$

*

*

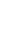


Variable seedeater

Great-tailed grackle

Yellow-tailed oriole
Sporophila corvina

Quiscalus mexicanus

$*$ 


\section{Appendix 2. Daily Wading Bird Counts By Species and Site at the Muisne River Estuary, Esmeraldas, Ecuador.}

\section{Total Birds}

\begin{tabular}{|c|c|c|c|c|c|c|c|c|c|c|c|c|c|c|c|c|}
\hline Habitat & Site & $80 \mathrm{oct} 04$ & $120 \mathrm{ct} 04$ & $150 \mathrm{CtO} 04$ & $200 \mathrm{ct} 04$ & $240 \mathrm{ct04}$ & $280 \mathrm{ct04}$ & $5 \mathrm{Nov} 04$ & 15 Nov04 & $23 \mathrm{Feb} 05$ & $26 \mathrm{Feb} 05$ & $3 \mathrm{Mar} 05$ & $9 \mathrm{Mar} 05$ & $16 \mathrm{Mar} 05$ & 19Mar05 & Mean \\
\hline Pond & 1 & 0 & 1 & 1 & 0 & 0 & 0 & 0 & 0 & 0 & 0 & 0 & 0 & 0 & 0 & 0.14 \\
\hline Pond & 2 & 0 & 7 & 4 & 8 & 11 & 143 & 4 & 5 & 0 & 3 & 3 & 1 & 0 & 15 & 14.57 \\
\hline Pond & 3 & 23 & 3 & 10 & 13 & 7 & 2 & 16 & 9 & 1 & 3 & 6 & 9 & 2 & 13 & 8.36 \\
\hline Pond & 4 & 71 & 8 & 11 & 7 & 7 & 12 & 5 & 7 & 24 & 3 & 6 & 11 & 12 & 6 & 13.57 \\
\hline Pond & 5 & 0 & 5 & 6 & 8 & 7 & 66 & 4 & 5 & 2 & 2 & 17 & 5 & 4 & 7 & 9.86 \\
\hline Pond & 6 & 0 & 0 & 1169 & 158 & 42 & 2 & 10 & 3 & 0 & 1 & 12 & 3 & 1 & 9 & 100.71 \\
\hline Pond & 7 & 0 & 32 & 37 & 26 & 16 & 2 & 53 & 5 & 3 & 3 & 7 & 11 & 4 & 14 & 15.21 \\
\hline Pond & 8 & 0 & 0 & 1 & 8 & 3 & 0 & 7 & 0 & 1 & 0 & 0 & 1 & 0 & 6 & 1.93 \\
\hline Mudflat & 9 & 3 & 0 & 0 & 0 & 0 & 0 & 2 & 0 & 0 & 0 & 0 & 0 & 0 & 0 & 0.36 \\
\hline Mudflat & 10 & 0 & 2 & 1 & 3 & 0 & 0 & 2 & 1 & 0 & 0 & 1 & 1 & 0 & 0 & 0.79 \\
\hline Mudflat & 11 & 0 & 7 & 0 & 3 & 0 & 2 & 0 & 1 & 2 & 0 & 2 & 4 & 1 & 0 & 1.57 \\
\hline Mudflat & 12 & 1 & 6 & 1 & 2 & 1 & 1 & 1 & 4 & 0 & 1 & 0 & 0 & 0 & 0 & 1.29 \\
\hline Mudflat & 13 & 0 & 0 & 0 & 0 & 0 & 0 & 0 & 0 & 0 & 0 & 0 & 0 & 0 & 2 & 0.14 \\
\hline Mudflat & 14 & 6 & 0 & 3 & 0 & 3 & 1 & 0 & 0 & 2 & 0 & 1 & 4 & 1 & 2 & 1.64 \\
\hline Mudflat & 15 & 0 & 0 & 0 & 0 & 3 & 3 & 1 & 0 & 0 & 0 & 0 & 0 & 2 & 5 & 1.00 \\
\hline Mudflat & 16 & 2 & 3 & 5 & 5 & 5 & 6 & 2 & 8 & 3 & 15 & 1 & 5 & 0 & 0 & 4.29 \\
\hline Mudflat & 17 & 81 & 151 & 132 & 67 & 349 & 107 & 0 & 84 & 370 & 64 & 0 & 0 & 167 & 5 & 112.64 \\
\hline Mudfhat & 18 & 10 & 0 & 0 & 0 & 0 & 0 & 0 & 0 & 0 & 0 & 0 & 0 & 0 & 0 & 0.71 \\
\hline Mudflat & 19 & 5 & 98 & 169 & 129 & 33 & 60 & 0 & 57 & 165 & 63 & 0 & 460 & 39 & 2 & 91.43 \\
\hline Mean & & 10.63 & 17.00 & 81.58 & 23.00 & 25.63 & 21.42 & 5.63 & 9.95 & 30.16 & 8.32 & 2.95 & 27.11 & 12.26 & 4.53 & 20.01 \\
\hline
\end{tabular}


Appendix 2, continued. Daily Wading Bird Counts By Species and Site at the Muisne River Estuary, Esmeraldas, Ecuador.

Ardea alba

\begin{tabular}{|c|c|c|c|c|c|c|c|c|c|c|c|c|c|c|c|c|}
\hline Habitat & Site & $80 \mathrm{ct} 04$ & $120 \mathrm{ct} 04$ & $150 \mathrm{ct} 04$ & $200 \mathrm{ct} 04$ & $24 \mathrm{Oct} 04$ & $280 \mathrm{ct} 04$ & 5Nov04 & 15 Nov04 & $23 \mathrm{Feb} 05$ & $26 \mathrm{Feb} 05$ & 3 Mar05 & 9 Mar05 & $16 \mathrm{Mar} 05$ & $19 \mathrm{Mar} 05$ & Mean \\
\hline Pond & 1 & 0 & 0 & 1 & 0 & 0 & 0 & 0 & 0 & 0 & 0 & 0 & 0 & 0 & 0 & 0.07 \\
\hline Pond & 2 & 0 & 3 & 1 & 2 & 3 & 8 & 2 & 0 & 0 & 0 & 0 & 0 & 0 & 0 & 1.36 \\
\hline Pond & 3 & 18 & 1 & 6 & 3 & 0 & 0 & 3 & 0 & 0 & 0 & 1 & 2 & 0 & 0 & 2.43 \\
\hline Pond & 4 & 64 & 4 & 1 & 1 & 0 & 3 & 0 & 0 & 7 & 0 & 0 & 0 & 1 & 0 & 5.79 \\
\hline Pond & 5 & 0 & 2 & 1 & 1 & 3 & 3 & 0 & 0 & 2 & 0 & 1 & 0 & 1 & 2 & 1.14 \\
\hline Pond & 6 & 0 & 0 & 379 & 32 & 7 & 0 & 2 & 0 & 0 & 0 & 0 & 0 & 0 & 1 & 30.07 \\
\hline Pond & 7 & 0 & 24 & 36 & 7 & 10 & 0 & 26 & 4 & 1 & 0 & 0 & 0 & 0 & 1 & 7.79 \\
\hline Pond & 8 & 0 & 0 & 1 & 3 & 0 & 0 & 2 & 0 & 0 & 0 & 0 & 1 & 0 & 0 & 0.50 \\
\hline Mudnlat & 9 & 0 & 0 & 0 & 0 & 0 & 0 & 0 & 0 & 0 & 0 & 0 & 0 & 0 & 0 & 0.00 \\
\hline Mudflat & 10 & 0 & 0 & 0 & 0 & 0 & 0 & 0 & 0 & 0 & 0 & 0 & 0 & 0 & 0 & 0.00 \\
\hline Mudflat & 11 & 0 & 0 & 0 & 0 & 0 & 1 & 0 & 0 & 0 & 0 & 0 & 0 & 0 & 0 & 0.07 \\
\hline Mudflat & 12 & 0 & 0 & 0 & 0 & 0 & 0 & 0 & 0 & 0 & 0 & 0 & 0 & 0 & 0 & 0.00 \\
\hline Mudflat & 13 & 0 & 0 & 0 & 0 & 0 & 0 & 0 & 0 & 0 & 0 & 0 & 0 & 0 & 0 & 0.00 \\
\hline Mudflat & 14 & 1 & 0 & 0 & 0 & 0 & 1 & 0 & 0 & 2 & 0 & 1 & 1 & 1 & 0 & 0.50 \\
\hline Mudflat & 15 & 0 & 0 & 0 & 0 & 0 & 0 & 1 & 0 & 0 & 0 & 0 & 0 & 0 & 2 & 0.21 \\
\hline Mudflat & 16 & 1 & 0 & 1 & 2 & 0 & 1 & 0 & 2 & 0 & 0 & 0 & 0 & 0 & 0 & 0.50 \\
\hline Mudflat & 17 & 2 & 12 & 4 & 4 & 58 & 1 & 0 & 2 & 34 & 0 & 0 & 0 & 11 & 5 & 9.50 \\
\hline Mudflat & 18 & 1 & 0 & 0 & 0 & 0 & 0 & 0 & 0 & 0 & 0 & 0 & 0 & 0 & 0 & 0.07 \\
\hline Mudflat & 19 & 1 & 2 & 3 & 1 & 1 & 0 & 0 & 2 & 1 & 2 & 0 & 36 & 1 & 0 & 3.57 \\
\hline Mean & & 4.63 & 2.53 & 22.84 & 2.95 & 4.32 & 0.95 & 1.89 & 0.53 & 2.47 & 0.11 & 0.16 & 2.11 & 0.79 & 0.58 & 3.35 \\
\hline
\end{tabular}




\section{Appendix 2, continued. Daily Wading Bird Counts By Species and Site at the Muisne River Estuary, Esmeraldas, Ecuador.}

\section{Ardea cocoi}

\begin{tabular}{|c|c|c|c|c|c|c|c|c|c|c|c|c|c|c|c|c|}
\hline Habitat & Site & $80 \mathrm{ct} 04$ & $120 \mathrm{ct} 04$ & $150 \mathrm{cr} 04$ & $200 \mathrm{ct} 04$ & $240 \mathrm{ct} 04$ & $280 \mathrm{ct} 04$ & 5 Nov04 & 15 Nov04 & $23 \mathrm{Feb05}$ & $26 \mathrm{Feb} 05$ & $3 \mathrm{Mar05}$ & 9 Mar05 & $16 \mathrm{Mar} 05$ & 19Mar05 & Mean \\
\hline Pond & 1 & 0 & 0 & 0 & 0 & 0 & 0 & 0 & 0 & 0 & 0 & 0 & 0 & 0 & 0 & 0.00 \\
\hline Pond & 2 & 0 & 0 & 0 & 0 & 0 & 0 & 0 & 0 & 0 & 0 & 0 & 0 & 0 & 0 & 0.00 \\
\hline Pond & 3 & 0 & 0 & 0 & 0 & 0 & 0 & 0 & 0 & 0 & 0 & 0 & 0 & 0 & 0 & 0.00 \\
\hline Pond & 4 & 0 & 0 & 0 & 0 & 0 & 0 & 0 & 0 & 0 & 0 & 0 & 0 & 0 & 0 & 0.00 \\
\hline Pond & 5 & 0 & 0 & 0 & 0 & 0 & 0 & 0 & 0 & 0 & 0 & 0 & 0 & 0 & 0 & 0.00 \\
\hline Pond & 6 & 0 & 0 & 0 & 0 & 0 & 0 & 1 & 0 & 0 & 0 & 0 & 0 & 0 & 0 & 0.07 \\
\hline Pond & 7 & 0 & 0 & 0 & 0 & 0 & 0 & 0 & 0 & 0 & 0 & 0 & 0 & 0 & 0 & 0.00 \\
\hline Pond & 8 & 0 & 0 & 0 & 0 & 0 & 0 & 0 & 0 & 0 & 0 & 0 & 0 & 0 & 0 & 0.00 \\
\hline Mudflat & 9 & 0 & 0 & 0 & 0 & 0 & 0 & 0 & 0 & 0 & 0 & 0 & 0 & 0 & 0 & 0.00 \\
\hline Mudflat & 10 & 0 & 0 & 0 & 0 & 0 & 0 & 0 & 0 & 0 & 0 & 0 & 0 & 0 & 0 & 0.00 \\
\hline Mudflat & 11 & 0 & 1 & 0 & 0 & 0 & 0 & 0 & 0 & 0 & 0 & 0 & 0 & 0 & 0 & 0.07 \\
\hline Mudflat & 12 & 0 & 0 & 0 & 0 & 0 & 0 & 0 & 0 & 0 & 0 & 0 & 0 & 0 & 0 & 0.00 \\
\hline Mudflat & 13 & 0 & 0 & 0 & 0 & 0 & 0 & 0 & 0 & 0 & 0 & 0 & 0 & 0 & 0 & 0.00 \\
\hline Mudflat & 14 & 0 & 0 & 0 & 0 & 0 & 0 & 0 & 0 & 0 & 0 & 0 & 0 & 0 & 0 & 0.00 \\
\hline Mudflat & 15 & 0 & 0 & 0 & 0 & 0 & 0 & 0 & 0 & 0 & 0 & 0 & 0 & 0 & 0 & 0.00 \\
\hline Mudflat & 16 & 0 & 0 & 0 & 0 & 0 & 0 & 0 & 0 & 0 & 0 & 0 & 0 & 0 & 0 & 0.00 \\
\hline Mudflat & 17 & 0 & 0 & 0 & 0 & 0 & 0 & 0 & 0 & 0 & 0 & 0 & 0 & 0 & 0 & 0.00 \\
\hline Mudflat & 18 & 2 & 0 & 0 & 0 & 0 & 0 & 0 & 0 & 0 & 0 & 0 & 0 & 0 & 0 & 0.14 \\
\hline Mudflat & 19 & 0 & 0 & 0 & 0 & 0 & 0 & 0 & 0 & 0 & 0 & 0 & 0 & 0 & 0 & 0.00 \\
\hline Mean & & 0.11 & 0.05 & 0.00 & 0.00 & 0.00 & 0.00 & 0.05 & 0.00 & 0.00 & 0.00 & 0.00 & 0.00 & 0.00 & 0.00 & 0.02 \\
\hline
\end{tabular}


Appendix 2, continued. Daily Wading Bird Counts By Species and Site at the Muisne River Estuary, Esmeraldas, Ecuador.

\section{Butorides striatus}

\begin{tabular}{|c|c|c|c|c|c|c|c|c|c|c|c|c|c|c|c|c|}
\hline Habitat & Site & $80 \mathrm{ct} 04$ & $120 \mathrm{ct} 04$ & $150 \mathrm{ct04}$ & $200 \mathrm{ct} 04$ & $240 \mathrm{ct} 04$ & $280 \mathrm{ct} 04$ & 5 Nov04 & 15 Nov04 & 23Feb05 & $26 \mathrm{Feb} 05$ & $3 \mathrm{Mar} 05$ & $9 \mathrm{Mar} 0 \mathrm{~S}$ & $16 \mathrm{Mar} 05$ & 19Mar05 & Mean \\
\hline Pond & 1 & 0 & 0 & 0 & 0 & 0 & 0 & 0 & 0 & 0 & 0 & 0 & 0 & 0 & 0 & 0.00 \\
\hline Pond & 2 & 0 & 0 & 0 & 0 & 0 & 0 & 0 & 0 & 0 & 0 & 0 & 0 & 0 & 0 & 0.00 \\
\hline Pond & 3 & 0 & 1 & 0 & 0 & 0 & 0 & 0 & 0 & 0 & 0 & 1 & 1 & 0 & 0 & 0.21 \\
\hline Pond & 4 & 2 & 0 & 0 & 0 & 0 & 0 & 0 & 0 & 1 & 0 & 0 & 1 & 0 & 0 & 0.29 \\
\hline Pond & 5 & 0 & 0 & 0 & 1 & 0 & 0 & 0 & 0 & 0 & 0 & 0 & 0 & 0 & 0 & 0.07 \\
\hline Pond & 6 & 0 & 0 & 2 & 0 & 0 & 0 & 1 & 0 & 0 & 0 & 0 & 0 & 0 & 0 & 0.21 \\
\hline Pond & 7 & 0 & 0 & 0 & 0 & 0 & 0 & 0 & 0 & 0 & 0 & 0 & 0 & 0 & 0 & 0.00 \\
\hline Pond & 8 & 0 & 0 & 0 & 0 & 0 & 0 & 0 & 0 & 0 & 0 & 0 & 0 & 0 & 0 & 0.00 \\
\hline Mudflat & 9 & 1 & 0 & 0 & 0 & 0 & 0 & 1 & 0 & 0 & 0 & 0 & 0 & 0 & 0 & 0.14 \\
\hline Mudflat & 10 & 0 & 0 & 1 & 2 & 0 & 0 & 0 & 0 & 0 & 0 & 0 & 0 & 0 & 0 & 0.21 \\
\hline Mudflat & 11 & 0 & 0 & 0 & 0 & 0 & 0 & 0 & 0 & 0 & 0 & 0 & 1 & 0 & 0 & 0.07 \\
\hline Mudflat & 12 & 1 & 0 & 0 & 0 & 0 & 0 & 0 & 0 & 0 & 0 & 0 & 0 & 0 & 0 & 0.07 \\
\hline Mudflat & 13 & 0 & 0 & 0 & 0 & 0 & 0 & 0 & 0 & 0 & 0 & 0 & 0 & 0 & 0 & 0.00 \\
\hline Mudflat & 14 & 0 & 0 & 0 & 0 & 0 & 0 & 0 & 0 & 0 & 0 & 0 & 0 & 0 & 0 & 0.00 \\
\hline Mudflat & 15 & 0 & 0 & 0 & 0 & 0 & 0 & 0 & 0 & 0 & 0 & 0 & 0 & 0 & 0 & 0.00 \\
\hline Mudflat & 16 & 0 & 0 & 0 & 0 & 0 & 0 & 0 & 0 & 0 & 0 & 0 & 0 & 0 & 0 & 0.00 \\
\hline Mudflat & 17 & 0 & 0 & 1 & 1 & 0 & 1 & 0 & 0 & 0 & 0 & 0 & 0 & 0 & 0 & 0.21 \\
\hline Mudflat & 18 & 1 & 0 & 0 & 0 & 0 & 0 & 0 & 0 & 0 & 0 & 0 & 0 & 0 & 0 & 0.07 \\
\hline Mudflat & 19 & 0 & 0 & 0 & 0 & 0 & 0 & 0 & 0 & 0 & 1 & 0 & 2 & 1 & 1 & 0.36 \\
\hline Mean & & 0.26 & 0.05 & 0.21 & 0.21 & 0.00 & 0.05 & 0.11 & 0.00 & 0.05 & 0.05 & 0.05 & 0.26 & 0.05 & 0.05 & 0.10 \\
\hline
\end{tabular}


Appendix 2, continued. Daily Wading Bird Counts By Species and Site at the Muisne River Estuary, Esmeraldas, Ecuador.

\section{Egretta caerulea}

\begin{tabular}{|c|c|c|c|c|c|c|c|c|c|c|c|c|c|c|c|c|}
\hline Habitat & Site & $80 \mathrm{ct} 04$ & $120 \mathrm{ct} 04$ & $150 \mathrm{ct} 04$ & $200 c t 04$ & $240 \mathrm{ct} 04$ & $280 \mathrm{ct} 04$ & 5 Nov04 & 15 Nov04 & 23Feb05 & $26 \mathrm{Feb} 05$ & $3 \mathrm{Mar} 0 \mathrm{~s}$ & $9 \mathrm{MarOS}$ & $16 \mathrm{Mar} 05$ & $19 \mathrm{Mar0s}$ & Mean \\
\hline Pond & 1 & 0 & 0 & 0 & 0 & 0 & 0 & 0 & 0 & 0 & 0 & 0 & 0 & 0 & 0 & 0.00 \\
\hline Pond & 2 & 0 & 1 & 0 & 4 & 3 & 27 & 0 & 2 & 0 & 2 & 0 & 1 & 0 & 0 & 2.86 \\
\hline Pond & 3 & 2 & 1 & 2 & 4 & 4 & 0 & 9 & 1 & 1 & 3 & 2 & 2 & 2 & 12 & 3.21 \\
\hline Pond & 4 & 2 & 2 & 1 & 2 & 1 & 4 & 1 & 2 & 12 & 2 & 1 & 3 & 9 & 5 & 3.36 \\
\hline Pond & 5 & 0 & 0 & 3 & 2 & 1 & 11 & 1 & 1 & 0 & 0 & 1 & 1 & 3 & 3 & 1.93 \\
\hline Pond & 6 & 0 & 0 & 26 & 28 & 10 & 0 & 1 & 2 & 0 & 1 & 0 & 2 & 0 & 4 & 5.29 \\
\hline Pond & 7 & 0 & 1 & 0 & 3 & 2 & 2 & 1 & 1 & 1 & 1 & 1 & 2 & 2 & 3 & 1.43 \\
\hline Pond & 8 & 0 & 0 & 0 & 1 & 0 & 0 & 1 & 0 & 1 & 0 & 0 & 0 & 0 & 0 & 0.21 \\
\hline Mudflat & 9 & 0 & 0 & 0 & 0 & 0 & 0 & 0 & 0 & 0 & 0 & 0 & 0 & 0 & 0 & 0.00 \\
\hline Mudflat & 10 & 0 & 2 & 0 & 0 & 0 & 0 & 2 & 0 & 0 & 0 & 0 & 0 & 0 & 0 & 0.29 \\
\hline Mudflat & 11 & 0 & 6 & 0 & 3 & 0 & 0 & 0 & 0 & 2 & 0 & 2 & 2 & 0 & 0 & 1.07 \\
\hline Mudflat & 12 & 0 & 0 & 0 & 1 & 0 & 1 & 0 & 1 & 0 & 1 & 0 & 0 & 0 & 0 & 0.29 \\
\hline Mudflat & 13 & 0 & 0 & 0 & 0 & 0 & 0 & 0 & 0 & 0 & 0 & 0 & 0 & 0 & 1 & 0.07 \\
\hline Mudflat & 14 & 2 & 0 & 1 & 0 & 1 & 0 & 0 & 0 & 0 & 0 & 0 & 0 & 0 & 2 & 0.43 \\
\hline Mudflat & 15 & 0 & 0 & 0 & 0 & 0 & 0 & 0 & 0 & 0 & 0 & 0 & 0 & 0 & 0 & 0.00 \\
\hline Mudflat & 16 & 0 & 1 & 2 & 1 & 3 & 4 & 0 & 1 & 3 & 6 & 1 & 2 & 0 & 0 & 1.71 \\
\hline Mudflat & 17 & 44 & 62 & 52 & 6 & 61 & 61 & 0 & 36 & 63 & 40 & 0 & 0 & 57 & 0 & 34.43 \\
\hline Mudflat & 18 & 4 & 0 & 0 & 0 & 0 & 0 & 0 & 0 & 0 & 0 & 0 & 0 & 0 & 0 & 0.29 \\
\hline Mudnlat & 19 & 1 & 17 & 21 & 44 & 1 & 20 & 0 & 20 & 42 & 39 & 0 & 101 & 6 & 1 & 22.36 \\
\hline Mean & & 2.89 & 4.89 & 5.68 & 5.21 & 4.58 & 6.84 & 0.84 & 3.53 & 6.58 & 5.00 & 0.42 & 6.11 & 4.16 & 1.63 & 4.17 \\
\hline
\end{tabular}


Appendix 2, continued. Daily Wading Bird Counts By Species and Site at the Muisne River Estuary, Esmeraldas, Ecuador.

\section{Egretta thula}

\begin{tabular}{|c|c|c|c|c|c|c|c|c|c|c|c|c|c|c|c|c|}
\hline Habitat & Site & $80 \mathrm{ct04}$ & $120 \mathrm{ct} 04$ & $150 \mathrm{ct} 04$ & $200 \mathrm{ct04}$ & $240 \mathrm{ct} 04$ & $280 \mathrm{ct} 04$ & SNov04 & $15 \mathrm{Nov} 04$ & 23 Feb0s & $26 \mathrm{Feb} 05$ & 3Mar0s & 9 Mar0s & $16 \mathrm{Mar} 05$ & 19Mar05 & Mean \\
\hline Pond & 1 & 0 & 1 & 0 & 0 & 0 & 0 & 0 & 0 & 0 & 0 & 0 & 0 & 0 & 0 & 0.07 \\
\hline Pond & 2 & 0 & 3 & 2 & 1 & 3 & 106 & 1 & 2 & 0 & 0 & 2 & 0 & 0 & 15 & 9.64 \\
\hline Pond & 3 & 3 & 0 & 1 & 3 & 3 & 2 & 3 & 7 & 0 & 0 & 2 & 2 & 0 & 1 & 1.93 \\
\hline Pond & 4 & 2 & 2 & 4 & 4 & 2 & 3 & 3 & 3 & 0 & 1 & 3 & 2 & 1 & 0 & 2.14 \\
\hline Pond & 5 & 0 & 2 & 2 & 2 & 3 & 50 & 2 & 3 & 0 & 0 & 15 & 3 & 0 & 2 & 6.00 \\
\hline Pond & 6 & 0 & 0 & 758 & 96 & 22 & 2 & 5 & 1 & 0 & 0 & 11 & 0 & 1 & 3 & 64.21 \\
\hline Pond & 7 & 0 & 7 & 1 & 16 & 4 & 0 & 26 & 0 & 1 & 2 & 4 & 9 & 2 & 10 & 5.86 \\
\hline Pond & 8 & 0 & 0 & 0 & 2 & 3 & 0 & 2 & 0 & 0 & 0 & 0 & 0 & 0 & 6 & 0.93 \\
\hline Mudflat & 9 & 2 & 0 & 0 & 0 & 0 & 0 & 0 & 0 & 0 & 0 & 0 & 0 & 0 & 0 & 0.14 \\
\hline Mudflat & 10 & 0 & 0 & 0 & 1 & 0 & 0 & 0 & 1 & 0 & 0 & 1 & 0 & 0 & 0 & 0.21 \\
\hline Mudflat & 11 & 0 & 0 & 0 & 0 & 0 & 0 & 0 & 0 & 0 & 0 & 0 & 1 & 1 & 0 & 0.14 \\
\hline Mudflat & 12 & 0 & 0 & 0 & 0 & 0 & 0 & 0 & 0 & 0 & 0 & 0 & 0 & 0 & 0 & 0.00 \\
\hline Mudflat & 13 & 0 & 0 & 0 & 0 & 0 & 0 & 0 & 0 & 0 & 0 & 0 & 0 & 0 & 1 & 0.07 \\
\hline Mudflat & 14 & 3 & 0 & 1 & 0 & 1 & 0 & 0 & 0 & 0 & 0 & 0 & 2 & 0 & 0 & 0.50 \\
\hline Mudflat & 15 & 0 & 0 & 0 & 0 & 0 & 0 & 0 & 0 & 0 & 0 & 0 & 0 & 1 & 2 & 0.21 \\
\hline Mudflat & 16 & 1 & 2 & 1 & 2 & 1 & 1 & 2 & 1 & 0 & 2 & 0 & 1 & 0 & 0 & 1.00 \\
\hline Mudflat & 17 & 27 & 41 & 64 & 49 & 203 & 27 & 0 & 32 & 244 & 2 & 0 & 0 & 82 & 0 & 55.07 \\
\hline Mudflat & 18 & 0 & 0 & 0 & 0 & 0 & 0 & 0 & 0 & 0 & 0 & 0 & 0 & 0 & 0 & 0.00 \\
\hline Mudflat & 19 & 2 & 55 & 127 & 69 & 16 & 13 & 0 & 10 & 109 & 12 & 0 & 299 & 18 & 0 & 52.14 \\
\hline Mean & & 2.11 & 5.95 & 50.58 & 12.89 & 13.74 & 10.74 & 2.32 & 3.16 & 18.63 & 1.00 & 2.00 & 16.79 & 5.58 & 2.11 & 10.54 \\
\hline
\end{tabular}


Appendix 2, continued. Daily Wading Bird Counts By Species and Site at the Muisne River Estuary, Esmeraldas, Ecuador.

\section{Egretta tricolor}

\begin{tabular}{|c|c|c|c|c|c|c|c|c|c|c|c|c|c|c|c|c|}
\hline Habitat & Site & $80 \mathrm{ct} 04$ & $120 \mathrm{ct} 04$ & $150 \mathrm{ct} 04$ & $200 \mathrm{ct} 04$ & $240 \mathrm{ct} 04$ & $280 \mathrm{ct} 04$ & 5 Nov04 & 15 Nov04 & $23 \mathrm{Feb} 05$ & $26 \mathrm{Feb} 05$ & $3 \mathrm{Mar} 05$ & $9 \mathrm{Mar} 05$ & 16Mar0s & $19 \mathrm{Mar} 05$ & Mean \\
\hline Pond & 1 & 0 & 0 & 0 & 0 & 0 & 0 & 0 & 0 & 0 & 0 & 0 & 0 & 0 & 0 & 0.00 \\
\hline Pond & 2 & 0 & 0 & 0 & 0 & 1 & 0 & 1 & 0 & 0 & 1 & 0 & 0 & 0 & 0 & 0.21 \\
\hline Pond & 3 & 0 & 0 & 0 & 0 & 0 & 0 & 1 & 1 & 0 & 0 & 0 & 2 & 0 & 0 & 0.29 \\
\hline Pond & 4 & 1 & 0 & 1 & 0 & 1 & 1 & 1 & 0 & 0 & 0 & 1 & 0 & 1 & 0 & 0.50 \\
\hline Pond & 5 & 0 & 1 & 0 & 2 & 0 & 2 & 1 & 0 & 0 & 0 & 0 & 0 & 0 & 0 & 0.43 \\
\hline Pond & 6 & 0 & 0 & 2 & 2 & 3 & 0 & 0 & 0 & 0 & 0 & 0 & 0 & 0 & 0 & 0.50 \\
\hline Pond & 7 & 0 & 0 & 0 & 0 & 0 & 0 & 0 & 0 & 0 & 0 & 0 & 0 & 0 & 0 & 0.00 \\
\hline Pond & 8 & 0 & 0 & 0 & 2 & 0 & 0 & 2 & 0 & 0 & 0 & 0 & 0 & 0 & 0 & 0.29 \\
\hline Mudflat & 9 & 0 & 0 & 0 & 0 & 0 & 0 & 1 & 0 & 0 & 0 & 0 & 0 & 0 & 0 & 0.07 \\
\hline Mudflat & 10 & 0 & 0 & 0 & 0 & 0 & 0 & 0 & 0 & 0 & 0 & 0 & 0 & 0 & 0 & 0.00 \\
\hline Mudflat & 11 & 0 & 0 & 0 & 0 & 0 & 1 & 0 & 0 & 0 & 0 & 0 & 0 & 0 & 0 & 0.07 \\
\hline Mudflat & 12 & 0 & 6 & 0 & 1 & 1 & 0 & 1 & 0 & 0 & 0 & 0 & 0 & 0 & 0 & 0.64 \\
\hline Mudflat & 13 & 0 & 0 & 0 & 0 & 0 & 0 & 0 & 0 & 0 & 0 & 0 & 0 & 0 & 0 & 0.00 \\
\hline Mudflat & 14 & 0 & 0 & 1 & 0 & 1 & 0 & 0 & 0 & 0 & 0 & 0 & 1 & 0 & 0 & 0.21 \\
\hline Mudflat & 15 & 0 & 0 & 0 & 0 & 3 & 3 & 0 & 0 & 0 & 0 & 0 & 0 & 1 & 1 & 0.57 \\
\hline Mudflat & 16 & 0 & 0 & 1 & 0 & 1 & 0 & 0 & 2 & 0 & 3 & 0 & 2 & 0 & 0 & 0.64 \\
\hline Mudflat & 17 & 7 & 1 & 11 & 6 & 25 & 5 & 0 & 10 & 10 & 8 & 0 & 0 & 13 & 0 & 6.86 \\
\hline Mudflat & 18 & 1 & 0 & 0 & 0 & 0 & 0 & 0 & 0 & 0 & 0 & 0 & 0 & 0 & 0 & 0.07 \\
\hline Mudflat & 19 & 1 & 24 & 10 & 11 & 14 & 27 & 0 & 7 & 12 & 8 & 0 & 11 & 8 & 0 & 9.50 \\
\hline Mean & & 0.53 & 1.68 & 1.37 & 1.26 & 2.63 & 2.05 & 0.42 & 1.05 & 1.16 & 1.05 & 0.05 & 0.84 & 1.21 & 0.05 & 1.10 \\
\hline
\end{tabular}


Appendix 2, continued. Daily Wading Bird Counts By Species and Site at the Muisne River Estuary, Esmeraldas, Ecuador.

\section{Eudicimus albus}

\begin{tabular}{|c|c|c|c|c|c|c|c|c|c|c|c|c|c|c|c|c|}
\hline Habitat & Site & $80 c t 04$ & $120 \mathrm{ct}(04$ & $150 c 104$ & $200 \mathrm{ct} 04$ & $240 \mathrm{ct} 04$ & $280 \mathrm{ct04}$ & 5 Nov04 & 15 Nov04 & 23Feb05 & $26 \mathrm{Feb} 05$ & $3 \mathrm{Mar} 05$ & $9 \mathrm{Mar} 05$ & $16 \mathrm{Mar} 05$ & 19Maros & Mean \\
\hline Pond & 1 & 0 & 0 & 0 & 0 & 0 & 0 & 0 & 0 & 0 & 0 & 0 & 0 & 0 & 0 & 0.00 \\
\hline Pond & 2 & 0 & 0 & 0 & 0 & 0 & 2 & 0 & 0 & 0 & 0 & 0 & 0 & 0 & 0 & 0.14 \\
\hline Pond & 3 & 0 & 0 & 0 & 0 & 0 & 0 & 0 & 0 & 0 & 0 & 0 & 0 & 0 & 0 & 0.00 \\
\hline Pond & 4 & 0 & 0 & 0 & 0 & 0 & 0 & 0 & 0 & 0 & 0 & 0 & 0 & 0 & 0 & 0.00 \\
\hline Pond & 5 & 0 & 0 & 0 & 0 & 0 & 0 & 0 & 0 & 0 & 0 & 0 & 0 & 0 & 0 & 0.00 \\
\hline Pond & 6 & 0 & 0 & 0 & 0 & 0 & 0 & 0 & 0 & 0 & 0 & 0 & 0 & 0 & 0 & 0.00 \\
\hline Pond & 7 & 0 & 0 & 0 & 0 & 0 & 0 & 0 & 0 & 0 & 0 & 0 & 0 & 0 & 0 & 0.00 \\
\hline Pond & 8 & 0 & 0 & 0 & 0 & 0 & 0 & 0 & 0 & 0 & 0 & 0 & 0 & 0 & 0 & 0.00 \\
\hline Mudflat & 9 & 0 & 0 & 0 & 0 & 0 & 0 & 0 & 0 & 0 & 0 & 0 & 0 & 0 & 0 & 0.00 \\
\hline Mudflat & 10 & 0 & 0 & 0 & 0 & 0 & 0 & 0 & 0 & 0 & 0 & 0 & 0 & 0 & 0 & 0.00 \\
\hline Mudflat & 11 & 0 & 0 & 0 & 0 & 0 & 0 & 0 & 0 & 0 & 0 & 0 & 0 & 0 & 0 & 0.00 \\
\hline Mudflat & 12 & 0 & 0 & 0 & 0 & 0 & 0 & 0 & 0 & 0 & 0 & 0 & 0 & 0 & 0 & 0.00 \\
\hline Mudflat & 13 & 0 & 0 & 0 & 0 & 0 & 0 & 0 & 0 & 0 & 0 & 0 & 0 & 0 & 0 & 0.00 \\
\hline Mudnat & 14 & 0 & 0 & 0 & 0 & 0 & 0 & 0 & 0 & 0 & 0 & 0 & 0 & 0 & 0 & 0.00 \\
\hline Mudflat & 15 & 0 & 0 & 0 & 0 & 0 & 0 & 0 & 0 & 0 & 0 & 0 & 0 & 0 & 0 & 0.00 \\
\hline Mudflat & 16 & 0 & 0 & 0 & 0 & 0 & 0 & 0 & 0 & 0 & 0 & 0 & 0 & 0 & 0 & 0.00 \\
\hline Mudflat & 17 & 0 & 0 & 0 & 0 & 2 & 0 & 0 & 0 & 0 & 0 & 0 & 0 & 0 & 0 & 0.14 \\
\hline Mudflat & 18 & 0 & 0 & 0 & 0 & 0 & 0 & 0 & 0 & 0 & 0 & 0 & 0 & 0 & 0 & 0.00 \\
\hline Mudflat & 19 & 0 & 0 & 0 & 0 & 0 & 0 & 0 & 0 & 0 & 0 & 0 & 0 & 0 & 0 & 0.00 \\
\hline Mean & & 0.00 & 0.00 & 0.00 & 0.00 & 0.11 & 0.11 & 0.00 & 0.00 & 0.00 & 0.00 & 0.00 & 0.00 & 0.00 & 0.00 & 0.02 \\
\hline
\end{tabular}


Appendix 2, continued. Daily Wading Bird Counts By Species and Site at the Muisne River Estuary, Esmeraldas, Ecuador.

\section{Nycticorax nycticorax}

\begin{tabular}{|c|c|c|c|c|c|c|c|c|c|c|c|c|c|c|c|c|}
\hline Habitat & Site & $80 \mathrm{ct} 04$ & $120 \mathrm{ct} 04$ & $150 \mathrm{ct} 04$ & $200 \mathrm{ct} 04$ & $240 \mathrm{ct} 04$ & $280 \mathrm{ct} 104$ & 5Nov04 & 15 Nov04 & $23 \mathrm{Feb} 05$ & 26 Feb05 & 3Mar05 & 9 Mar05 & $16 \mathrm{Mar} 05$ & 19Marios & Mean \\
\hline Pond & 1 & 0 & 0 & 0 & 0 & 0 & 0 & 0 & 0 & 0 & 0 & 0 & 0 & 0 & 0 & 0.00 \\
\hline Pond & 2 & 0 & 0 & 0 & 0 & 0 & 0 & 0 & 0 & 0 & 0 & 0 & 0 & 0 & 0 & 0.00 \\
\hline Pond & 3 & 0 & 0 & 0 & 0 & 0 & 0 & 0 & 0 & 0 & 0 & 0 & 0 & 0 & 0 & 0.00 \\
\hline Pond & 4 & 0 & 0 & 0 & 0 & 0 & 0 & 0 & 0 & 0 & 0 & 0 & 0 & 0 & 0 & 0.00 \\
\hline Pond & 5 & 0 & 0 & 0 & 0 & 0 & 0 & 0 & 0 & 0 & 0 & 0 & 0 & 0 & 0 & 0.00 \\
\hline Pond & 6 & 0 & 0 & 0 & 0 & 0 & 0 & 0 & 0 & 0 & 0 & 0 & 1 & 0 & 0 & 0.07 \\
\hline Pond & 7 & 0 & 0 & 0 & 0 & 0 & 0 & 0 & 0 & 0 & 0 & 0 & 0 & 0 & 0 & 0.00 \\
\hline Pond & 8 & 0 & 0 & 0 & 0 & 0 & 0 & 0 & 0 & 0 & 0 & 0 & 0 & 0 & 0 & 0.00 \\
\hline Mudflat & 9 & 0 & 0 & 0 & 0 & 0 & 0 & 0 & 0 & 0 & 0 & 0 & 0 & 0 & 0 & 0.00 \\
\hline Mudflat & 10 & 0 & 0 & 0 & 0 & 0 & 0 & 0 & 0 & 0 & 0 & 0 & 0 & 0 & 0 & 0.00 \\
\hline Mudflat & 11 & 0 & 0 & 0 & 0 & 0 & 0 & 0 & 0 & 0 & 0 & 0 & 0 & 0 & 0 & 0.00 \\
\hline Mudflat & 12 & 0 & 0 & 0 & 0 & 0 & 0 & 0 & 0 & 0 & 0 & 0 & 0 & 0 & 0 & 0.00 \\
\hline Mudflat & 13 & 0 & 0 & 0 & 0 & 0 & 0 & 0 & 0 & 0 & 0 & 0 & 0 & 0 & 0 & 0.00 \\
\hline Mudflat & 14 & 0 & 0 & 0 & 0 & 0 & 0 & 0 & 0 & 0 & 0 & 0 & 0 & 0 & 0 & 0.00 \\
\hline Mudflat & 15 & 0 & 0 & 0 & 0 & 0 & 0 & 0 & 0 & 0 & 0 & 0 & 0 & 0 & 0 & 0.00 \\
\hline Mudflat & 16 & 0 & 0 & 0 & 0 & 0 & 0 & 0 & 0 & 0 & 0 & 0 & 0 & 0 & 0 & 0.00 \\
\hline Mudflat & 17 & 0 & 0 & 0 & 0 & 0 & 0 & 0 & 0 & 0 & 0 & 0 & 0 & 0 & 0 & 0.00 \\
\hline Mudflat & 18 & 0 & 0 & 0 & 0 & 0 & 0 & 0 & 0 & 0 & 0 & 0 & 0 & 0 & 0 & 0.00 \\
\hline Mudflat & 19 & 0 & 0 & 0 & 0 & 0 & 0 & 0 & 0 & 0 & 0 & 0 & 0 & 0 & 0 & 0.00 \\
\hline Mean & & 0.00 & 0.00 & 0.00 & 0.00 & 0.00 & 0.00 & 0.00 & 0.00 & 0.00 & 0.00 & 0.00 & 0.05 & 0.00 & 0.00 & 0.00 \\
\hline
\end{tabular}


Appendix 2, continued. Daily Wading Bird Counts By Species and Site at the Muisne River Estuary, Esmeraldas, Ecuador.

\section{Nycticorax violacea}

\begin{tabular}{|c|c|c|c|c|c|c|c|c|c|c|c|c|c|c|c|c|}
\hline Habitat & Site & $80 \mathrm{ct}(04$ & $120 \mathrm{ct}(1) 4$ & $150 \mathrm{Cl04}$ & $200 \mathrm{ct} 04$ & $240 \mathrm{ct} 04$ & $280 \mathrm{c} 104$ & 5Nov04 & 15 Nov04 & $23 \mathrm{Feb} 05$ & 26 Feb05 & $3 \mathrm{Mar05}$ & $9 \mathrm{Mar} 05$ & 16Mar05 & $19 \mathrm{Mar} 05$ & Mean \\
\hline Pond & 1 & 0 & 0 & 0 & 0 & 0 & 0 & 0 & 0 & 0 & 0 & 0 & 0 & 0 & 0 & 0.00 \\
\hline Pond & 2 & 0 & 0 & 1 & 1 & 1 & 0 & 0 & 1 & 0 & 0 & 1 & 0 & 0 & 0 & 0.36 \\
\hline Pond & 3 & 0 & 0 & 1 & 3 & 0 & 0 & 0 & 0 & 0 & 0 & 0 & 0 & 0 & 0 & 0.29 \\
\hline Pond & 4 & 0 & 0 & 4 & 0 & 3 & 1 & 0 & 2 & 4 & 0 & 1 & 5 & 0 & 1 & 1.50 \\
\hline Pond & 5 & 0 & 0 & 0 & 0 & 0 & 0 & 0 & 1 & 0 & 2 & 0 & 1 & 0 & 0 & 0.29 \\
\hline Pond & 6 & 0 & 0 & 2 & 0 & 0 & 0 & 0 & 0 & 0 & 0 & 1 & 0 & 0 & 1 & 0.29 \\
\hline Pond & 7 & 0 & 0 & 0 & 0 & 0 & 0 & 0 & 0 & 0 & 0 & 2 & 0 & 0 & 0 & 0.14 \\
\hline Pond & 8 & 0 & 0 & 0 & 0 & 0 & 0 & 0 & 0 & 0 & 0 & 0 & 0 & 0 & 0 & 0.00 \\
\hline Mudflat & 9 & 0 & 0 & 0 & 0 & 0 & 0 & 0 & 0 & 0 & 0 & 0 & 0 & 0 & 0 & 0.00 \\
\hline Mudflat & 10 & 0 & 0 & 0 & 0 & 0 & 0 & 0 & 0 & 0 & 0 & 0 & 1 & 0 & 0 & 0.07 \\
\hline Mudflat & 11 & 0 & 0 & 0 & 0 & 0 & 0 & 0 & 1 & 0 & 0 & 0 & 0 & 0 & 0 & 0.07 \\
\hline Mudflat & 12 & 0 & 0 & 1 & 0 & 0 & 0 & 0 & 3 & 0 & 0 & 0 & 0 & 0 & 0 & 0.29 \\
\hline Mudflat & 13 & 0 & 0 & 0 & 0 & 0 & 0 & 0 & 0 & 0 & 0 & 0 & 0 & 0 & 0 & 0.00 \\
\hline Mudflat & 14 & 0 & 0 & 0 & 0 & 0 & 0 & 0 & 0 & 0 & 0 & 0 & 0 & 0 & 0 & 0.00 \\
\hline Mudflat & 15 & 0 & 0 & 0 & 0 & 0 & 0 & 0 & 0 & 0 & 0 & 0 & 0 & 0 & 0 & 0.00 \\
\hline Mudflat & 16 & 0 & 0 & 0 & 0 & 0 & 0 & 0 & 2 & 0 & 4 & 0 & 0 & 0 & 0 & 0.43 \\
\hline Mudflat & 17 & 1 & 35 & 0 & 1 & 0 & 12 & 0 & 4 & 19 & 14 & 0 & 0 & 4 & 0 & 6.43 \\
\hline Mudflat & 18 & 1 & 0 & 0 & 0 & 0 & 0 & 0 & 0 & 0 & 0 & 0 & 0 & 0 & 0 & 0.07 \\
\hline Mudflat & 19 & 0 & 0 & 8 & 4 & 1 & 0 & 0 & 18 & 1 & 1 & 0 & 11 & 5 & 0 & 3.50 \\
\hline Mean & & 0.11 & 1.84 & 0.89 & 0.47 & 0.26 & 0.68 & 0.00 & 1.68 & 1.26 & 1.11 & 0.26 & 0.95 & 0.47 & 0.11 & 0.72 \\
\hline
\end{tabular}

